Aus der Abteilung Prothetik

(komm. Direktor: PD Dr. med. dent. N. Gersdorff)

im Zentrum Zahn-, Mund- und Kieferheilkunde

der Medizinischen Fakultät der Universität Göttingen

\title{
In vitro effects of periodontopathic bacteria on the proliferation and the osteogenic potential of human mesenchymal stem cells
}

\author{
INAUGURAL-DISSERTATION \\ zur Erlangung des Doktorgrades für Zahnheilkunde \\ der Medizinischen Fakultät \\ der Georg-August-Universität zu Göttingen
}

\author{
vorgelegt von \\ Ahmed Baligh \\ aus \\ Kairo / Ägypten
}

Göttingen 2012 
Dekan:

1. Berichterstatter: Prof. Dr. med. N. Miosge

2. Berichterstatter/in:

3. Berichterstatter/in:

Tag der mündlichen Prüfung:
Prof. Dr. med. M. Schön 
To my parents,

Frau Omayma Abou Zeid and Prof. Dr. Mohamed Baligh 


\section{Contents}

1 INTRODUCTION

1.1 The Periodontium 1

1.2 Periodontitis 2

1.3 PERIODONTAL REGENERATION BY APPLYING STEM CELLS 4

$\begin{array}{lll}\text { 1.3.1 MESENCHYMAL STEM CELLS (MSCS) } & 6\end{array}$

1.3.2 BONE MARROW DERIVED MESENCHYMAL STEM CELLS 6

$\begin{array}{ll}\text { 1.3.3 MSCS FOR PERIODONTAL REGENERATION } & 7\end{array}$

1.3.4 BMSCS VERSUS PDL DERIVED STEM CELLS IN PERIODONTAL REGENERATION

1.3.5 IMMORTALIZATION OF THE BMSCS 8

$\begin{array}{llr}1.4 & \text { BACTERIA INVOLVED IN PERIODONTITIS } & \mathbf{1 1}\end{array}$

$\begin{array}{lll}1.4 .1 & \text { ACTINOBACILLUS ACTINOMYCETEMCOMITANS } & 13\end{array}$

\begin{tabular}{ll}
1.4 .2 & 15 \\
\hline
\end{tabular}

$\begin{array}{lll}1.5 & \text { AIM OF THE STUDY } & 16\end{array}$

$\underline{\mathbf{2}}$ MATERIALS AND METHODS

$\begin{array}{llr}2.1 & \text { BACTERIA } & 17\end{array}$

$\begin{array}{llr}2.2 & \text { Cell CUlture } & 19\end{array}$

2.3 DETERMINATION OF THE GROWTH AND PROLIFERATION RATES OF THE MSCS WITH DIFFERENT RATIOS OF BACTERIA $\quad \mathbf{2 1}$

2.3.1 The Cellometer Auto T4 (NeXCelom Bioscience) 21

2.3.2 FLUORESCENCE-ACTIVATED CELL SORTING (FACS) ANALYSIS FOR KI-67 23

2.4 TESTING THE MSCS FOR STEM CELL MARKERS AFTER INCUBATION WITH BACTERIA $\mathbf{2 5}$

2.4.1 TESTiNG THE MSCS FOR THE STEM CELL MARKERS (CD44, CD29, CD166, AND CD105) WITH THE HELP OF IMMUNOHISTOCHEMISTRY AFTER 3 WEEKS OF INCUBATION WITH BACTERIA 25 2.4.2 TeSting the MSCS FOR THE STEMNESS MARKERS (KLF4 AND C-MYC) GENES AND THEIR ASSOCIATED EFFECTS ON THE OSTEOGENIC GENES (RUNX2 AND COL1) USING THE REAL TIME PCR AFTER 2 MONTHS OF INCUBATION WITH BACTERIA

2.5 OSTEOGENIC DIFFERENTIATION OF THE MSCS AFTER THE TWO MONTHS OF INCUBATION WITH BACTERIA

2.6 TESTING THE MSCS FOR THE OSTEOGENIC DIFFERENTIATION AFTER THE INCUBATION WITH THE OSTEOGENIC DIFFERENTIATION MEDIUM

2.6.1 ALKALINE PHOSPHATASE STAINING 33

2.6.2 TESTING THE MSCS FOR THE OSTEOGENIC DIFFERENTIATION WITH THE IMMUNOCYTOCHEMISTRY $\quad 35$

2.6.3 TESTING THE MSCS FOR THE DEGREE OF OSTEOGENIC DIFFERENTIATION USING THE REAL TIME PCR (TESTING THE EXPRESSION OF THE RUNX2 AND COL1 AFTER OSTEOGENIC DIFFERENTIATION) 
3.1 BACTERIAL GROWTH IN THE NORMAL CELL CULTURE MEDIUM

3.1.1 THE GROWTH RATE OF THE MSCS DURING THE PERIOD OF TWO MONTHS OF THE INCUBATION WITH THE BACTERIA

3.1.2 Counting OF THE CELLS With THE CELlometer DURing THE INCUBATION With THE BACTERIA

3.1.3 FACS (FLUORESCENCE-ACTIVATED CELL SORTING) ANALYSIS FOR KI-67 44

3.2 TESTING THE CELLS FOR STEM CELL MARKERS AFTER INCUBATION WITH BACTERIA $\mathbf{5 1}$

3.2.1 TESTING THE CELLS FOR THE STEM CELL MARKERS (CD44, CD29, CD166, AND CD105) WITH THE IMMUNOHISTOCHEMISTRY AFTER THREE WEEKS OF INCUBATION WITH BACTERIA 51 3.2.2 TeSting the MSCS FOR THE STEMNESS MARKERS (KLF4 AND C-MYC) GENES AND THEIR ASSOCIATED EFFECTS ON THE OSTEOGENIC GENES (RUNX2 AND COL1) USING THE REAL TIME PCR AFTER 2 MONTHS OF INCUBATION WITH BACTERIA

3.2.3 DETERMINATION OF THE RELATIVE EXPRESSION OF THE STEMNESS MARKERS (KLF4 AND CMYC) GENES AND THEIR ASSOCIATED EFFECTS ON THE OSTEOGENIC GENES (RUNX2 AND COL1) AFTER BACTERIAL INDUCTION

3.3 TESTING THE MSCS FOR THE OSTEOGENIC DIFFERENTIATION AFTER THE INCUBATION WITH THE OSTEOGENIC DIFFERENTIATION MEDIUM $\quad \mathbf{6 1}$

$\begin{array}{lll}\text { 3.3.1 ALKALINE PHOSPHATASE STAINING } & 62\end{array}$

3.3.2 TESTING THE MSCS FOR THE OSTEOGENIC DIFFERENTIATION WITH THE HELP OF IMMUNOCYTOCHEMISTRY $\quad 65$

3.3.3 TESTING THE MSCS FOR THE DEGREE OF OSTEOGENIC DIFFERENTIATION USING THE REAL TIME PCR (TESTING THE EXPRESSION OF THE RUNX2 AND COL1 AFTER OSTEOGENiC DIFFERENTIATION) 


\section{Abbreviations}

ATCC

Bglap

$\beta 2 \mathrm{M}$

${ }^{\circ} \mathrm{C}$

CD

cDNA

C-myc

Col1

DAPI

DEPC water

FACS

FITC

Fn1
American type culture collection

bone $\mathrm{y}$-carboxylglutamic acid-containing protein, it is also known as osteocalcin

beta 2 microglobulin

Celsius grades

cluster of differentiation

complementary deoxyribonucleic acid

clone of v-myc myelocytomatosis viral oncogene homolog

collagen type 1 gene

4', 6-diamidino-2-phenylindole

diethylpyrocarbonate treated water

fluorescence-activated cell sorting

fluorescein isothiocyanate

fibronectin 1 


\begin{tabular}{|c|c|}
\hline GATA6 & GATA binding factor 6 \\
\hline GFP & green fluorescence protein \\
\hline HPLF & human periodontal ligament fibroblasts \\
\hline HSPC & hematopoietic stem and progenitor cell \\
\hline hTERT & human telomerase reverse transcriptase \\
\hline lbsp & integrin-binding sialoprotein \\
\hline IFN & interferon \\
\hline $\lg G$ & immunoglobulin G \\
\hline IL & interleukin \\
\hline i.p. & intraperitoneal \\
\hline Ki-67 & kinase inhibitor 67 \\
\hline Klf4 & kruppel like factor 4 \\
\hline LIF & leukemia inhibitory factor \\
\hline$\mu g$ & microgram \\
\hline$\mu \mathrm{l}$ & microliter \\
\hline miRNA & microRNA \\
\hline
\end{tabular}


$\mathrm{ml}$

MMPs

MSCs

ng

N-myc

Oct4

PCR

PDGF

PDL

PE

PHA

RANKL

RLF/L-myc

RNA

rpm milliliter

matrix metalloproteinases

mesenchymal stem cells

nanogram

neuroblastoma derived v-myc myelocyto-matosis viral related oncogene

octamer-binding transcription factor 4

polymerase chain reaction

platelet derived growth factor

periodontal ligament

phycoerythrin

phytohemagglutinin A

receptor activator of nuclear factor kappa-B ligand

rearranged L-myc fusion gene

ribonucleic acid

revolution per minute 
Runx2

SCP

SD rats

Sox2

Spp1

STAT3

Th cells

TNF runt related transcription factor 2

single cell picked clones

Sprague Dawley rats

SRY (sex determining region Y)-box 2

secreted phosphoprotein 1, it is also known as osteopontin

signal transducer and activator of transcription 3

helper cells from the thymus

tumor necrosis factor 


\section{Introduction}

\subsection{The Periodontium}

Periodontium is the attachment apparatus, or the teeth holding apparatus, that is responsible for the anchorage of the teeth in their correct position. The periodontium or the periodontal holding apparatus consists mainly of gingiva, periodontal ligament (PDL), cementum, and alveolar bone (Tan et al. 2009, Mudda and Bajaj 2011, Yanagita et al. 2011).

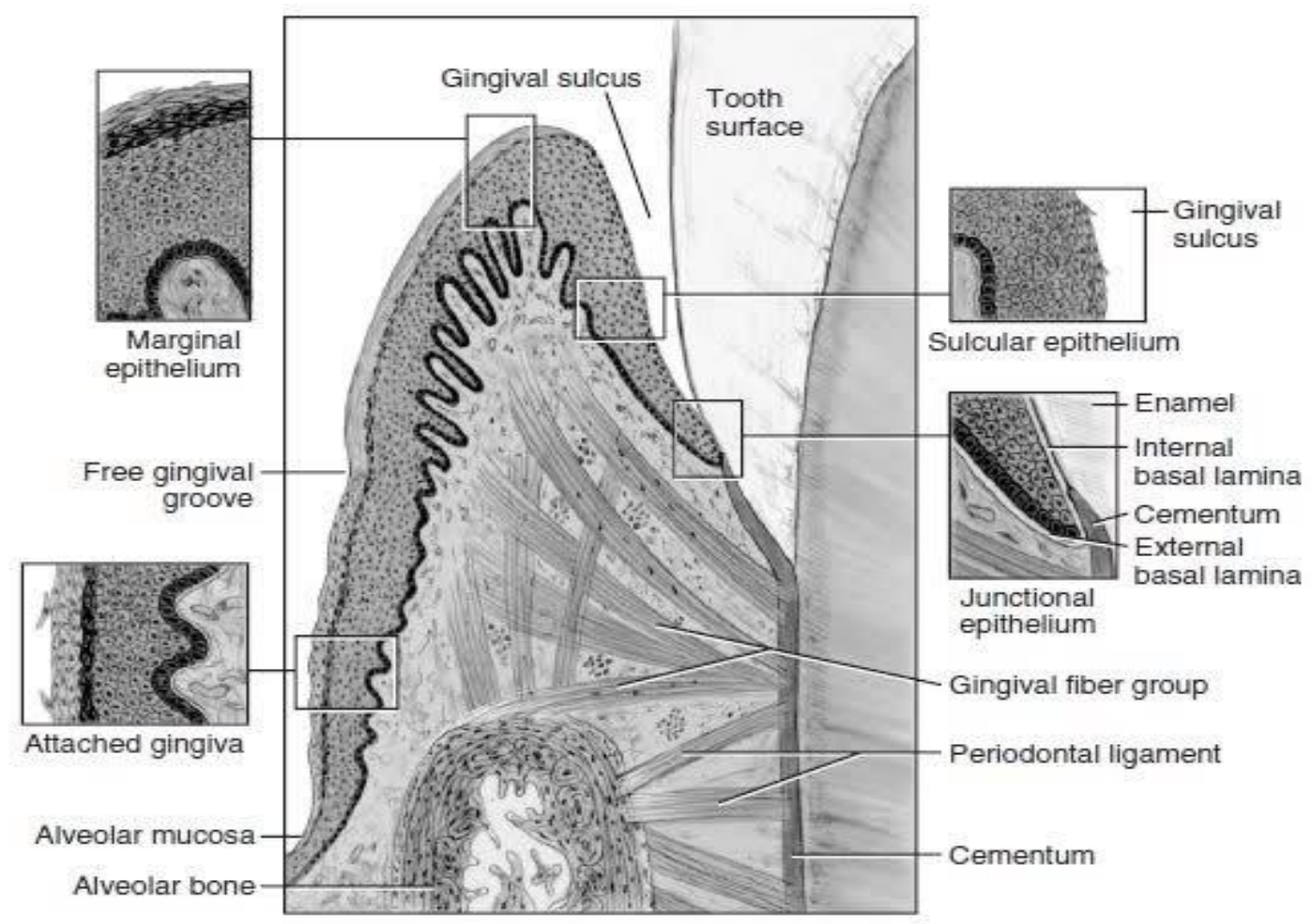

Figure 1: The normal anatomy of the periodontium, taken from: http://www.erdent.com (2012). 


\subsection{Periodontitis}

Periodontitis is a bacterial biofilm induced inflammatory disease that results in the destruction of the periodontal components including the destruction of the PDL, cementum, gingiva, and alveolar bone (Tan et al. 2009, Yanagita et al. 2011, Park et al. 2011).

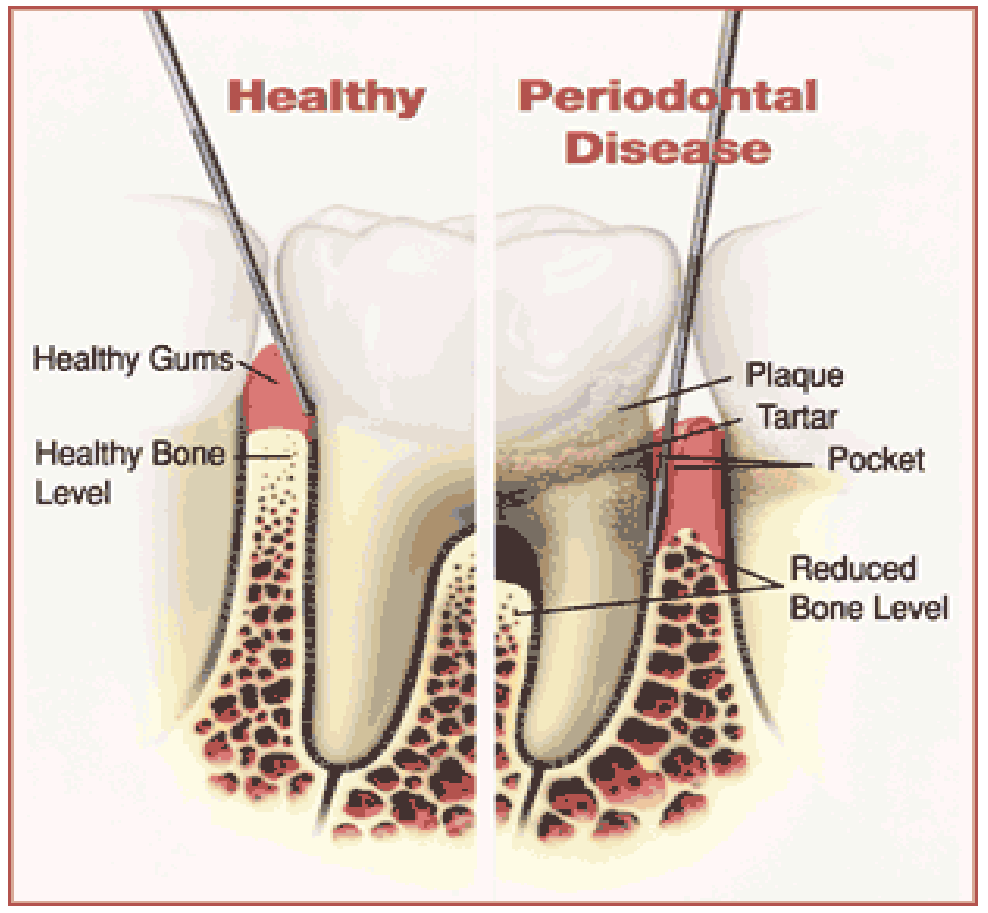

Figure 2: Healthy and diseased periodontium, taken from: http://www.perio.org (2012).

Periodontal disease results from the interactions of various etiologic factors including the subgingival microenvironment, social behavior, and genetic susceptibility of the individual host (Offenbacher 1996). Periodontitis is characterized by a dynamic nature of periods of remission and exacerbation. The cumulative destructive effect, associated with the exacerbation periods, results in the progressive destruction of the periodontal supporting structures and the subsequent loss of the teeth (Goodson et al. 1984, Haffajee et al. 
1983). Although the fact that the periodontal pathogens play a great role in the initiation of the disease, it was found that the major cause of the soft and hard tissue destruction associated with periodontitis is the activation of the hostimmune inflammatory response to the periodontal pathogenic challenge (Hernandez et al. 2011). This explains the periodic exacerbation-remission destructive nature of the disease that is associated with the activity periods of the inflammatory response of the host- immune system. During the periods of activity a certain inflammatory response is initiated in the periodontal tissues, this response is characterized first by the proliferation of the polymorphonuclear cells as a first line of innate immunity, resulting in the overproduction of a certain hypersecretory macrophage phenotype that is responsible for the synthesis and the secretion of the IL-1 $1 \beta, \mathrm{IL}-12$, and TNF- $\alpha$ cytokines (Hernandez et al. 2011). The secretion of these inflammatory cytokines is associated with the release of some matrix metalloproteinases (MMPs) such as, MMP-8, MMP-9, and MMP-13 from a certain latent form of neutrophils (Hernandez Rios et al. 2009, Mantyla et al. 2006). The MMPs are a group of proteinases that are involved in the host-immune inflammatory response including periodontitis (Folgueras et al. 2004). MMPs are able to degrade almost all the basement membrane and extracellular matrix components including type I collagen which is the main extracellular matrix component of soft and hard periodontal tissues (Golub et al. 1997). In cases of unresolved periodontal problem an adaptive inflammatory response is established that is characterized by the activation, proliferation, and differentiation of the naïve T-cells mainly to Th1 lymphocytes (responsible for the production of IL-2, IL-12, TNF- $\alpha$, TNF- $\beta$, and IFN- $\gamma$ cytokines), and Th2 cells (responsible for the secretion of IL-4, IL-5, IL-6, IL-9, and IL-13 cytokines). Recently, a new subset of $\mathrm{T}$ - cells has been described by Vernal and Garcia-Sanz known as Th-17 cells. The Th-17 cells display great proinflammatory and pro-resorptive activities through the secretion of IL-6, IL-21, IL-22, IL-23, IL-26, IL-17, and RANKL (Vernal et al. 2004, Vernal and GarciaSanz 2008). The Th-17 cells may contribute to bone resorption either indirectly through the secretion of IL- 6 and IL-17, which in turn increase the 
inflammatory response and induce RANKL expression by the osteoblastic cells, or directly through the direct secretion of RANKL and IL-17 which are highly involved in the differentiation and activation of osteoclasts with subsequent bone resorption (Dutzan et al. 2009, Hernandez et al. 2011).

It has been found that periodontal regeneration by conventional methods, for example, scaling, root planning, bone grafts, and barrier membranes might be effective in some cases. However, these conventional methods have shown some limitations with certain extensive cases. That is the main reason of the great concern about periodontal regeneration aided by the use of stem cells (Tan et al. 2009, Mudda and Bajaj 2011, Zhao et al. 2008, Park et al. 2011).

\subsection{Periodontal regeneration by applying stem cells}

Attempts of periodontal regeneration have been focusing mainly on regenerating the resorbed lost alveolar bone with the help of bone grafts, and alloplastic materials (Mudda and Bajaj 2011). Recently, with the great revolution in the field of regeneration using stem cell therapy (regenerative medicine), periodontists began to think and dream about achieving complete periodontal regeneration using stem cell therapy even in extensive cases in which conventional methods are not sufficient (Zhao et al. 2008, Mudda and Bajaj 2011, Shi et al. 2005, Chen YL et al. 2008).

Stem cells are undifferentiated cells that can self-renew, proliferate, and give birth to daughter cell lines which are able to differentiate into many mature cell types resulting in tissue generation (Leo and Grande 2006, Ivanovski et al. 2006). 
There are three main types of stem cells: totipotent, pluripotent, and multipotent stem cells.

\section{a) Totipotent stem cells}

Including embryonic stem cells, they are derived from the inner cell mass of the blastocyte, and they exhibit the ability to give birth to daughter cell lines that are able to differentiate to a large variety of tissues, approximately more than 200 different cell types (Umehara et al. 2007, Leo and Grande 2006, Ivanovski et al. 2006, Kiuru et al. 2009).

\section{b) Pluripotent stem cells}

They are similar to multipotent stem cells. However, they have the potential to form trophoblasts as well (Evans and Kaufman 1981, Jiang et al. 2002, Kiuru et al. 2009).

\section{c) Multipotent stem cells}

They show the least stemness characteristics of the three types of stem cells as their daughter cell lines can only differentiate to a few specific tissue types. However, they are preferred over the other stem cell types in a potential periodontal regeneration therapy due to the ease of obtaining and isolating them. Also, they are preferred regarding the ethical aspect (Ivanovski et al. 2006, Fortier 2005, Jiang et al. 2002).

Mesenchymal stem cells are considered as a subtype of this group of stem cells. 


\subsubsection{Mesenchymal stem cells (MSCs)}

The concept of a mesenchymal stem cell arose from the work of Friedenstein and colleagues four decades ago (Friedenstein et al. 1966, 1970, Jones and McGonagle 2008). MSCs are like all stem cells; they can self-renew, and they have the ability to proliferate and give birth to daughter cell lines which are able to differentiate to other mature cell types that have specific shapes, characteristics, and functions, and that is what makes MSCs play an important role in adult tissue repair (Song et al. 2006, Singer and Caplan 2011, Pittenger et al. 1999, Phinney and Prockop 2007, Fuchs 2012).

\subsubsection{Bone marrow derived mesenchymal stem cells}

Bone marrow mesenchymal stem cells, also known as bone marrow stromal cells (BMSCs) are isolated easily from single cell suspensions from bone marrow aspirates, as they adhere to the plates of the cell culture and show the characteristics of clonogenicity, this means that they are able to form a colony when they are being cultured with very low density, and that is what made the bone marrow to be considered as one of the most important sources of MSCs (Tan et al. 2009, Ye et al. 2012, Friedenstein et al. 1992, Simmons and Torok-Storb 1991, Morsczeck et al. 2008). 


\subsubsection{MSCs for periodontal regeneration}

The most important problem that has to be faced during the regeneration of the periodontium is the complex nature of the tissues that should be regenerated (soft and hard tissues like alveolar bone, cementum, and PDL). Due to this complex structure of the periodontium, its complete regeneration would require a multipotent cell population to be able to differentiate to these different tissues (Ivanovski et al. 2006, Maria et al. 2007). The mesenchymal origin of the different periodontal structures made a great concern to be directed towards the MSCs as a preferable source of stem cells for the regeneration of periodontal defects (Hasegawa et al. 2006, Maria et al. 2007, Kawaguchi et al. 2004).

\subsubsection{BMSCs versus PDL derived stem cells in periodontal regeneration}

It is believed that BMSCs are preferred over PDL derived stem cells in periodontal regeneration due to their superior availability, their better multilineage potential, and better, easier, and more comfortable culture properties, especially in the primary culture stage (Tan et al. 2009, Zhao et al. 2008). Furthermore, the way to expand a great number of PDL stem cells in a short period of time is still an unsolved problem (Zhao et al. 2008). On the other hand, the heterogeneous nature of the PDL containing blood vessels, connecting tissue fibers, and a great variety of cells, for example, fibroblasts, macrophages, undifferentiated ectomesenchymal cells, cementoblasts, cementoclasts, osteoblasts and osteoclasts, cell of Malassez, and cells of vascular and neural nature, made the PDL to be regarded as an unreliable source of pure homogeneous populations of stem cells (Tan et al. 2009, Zhao et al. 2008). 
From another aspect, some recent studies suggested that the PDL derived cells possess functional characteristics similar to those of leucocytes and macrophages that are involved in classical innate immunity (Souza et al. 2010, Almasri et al. 2007, Jönsson et al. 2008, 2009). These studies showed that the PDL cells can express and produce cytokines and chemokines in response to inflammatory stimulants, such as bacterial lipopolysaccharides, suggesting that PDL derived cells can act as immune cells producing inflammatory mediators under periodontopathic bacterial stimulation, and increasing the host-immune inflammatory response with subsequent increased periodontal destruction (Almasri et al. 2007, Jönsson et al. 2008, 2009, 2011). Another pervious study that was performed by Yamaji et al. also suggested that in vitro stimulation of the PDL derived fibroblasts with the lipopolysaccharides of the Porphyromonas gingivalis, stimulates their secretion of IL-6, and IL-8 into the culture medium (Yamaji et al. 1995).

\subsubsection{Immortalization of the BMSCs}

Although bone marrow is a preferable source of MSCs (Bianco et al. 2001), the amount of isolated MSCs from a single bone marrow aspirate is of low frequency to be used in vivo. Therefore, in vitro culture and expansion of isolated MSCs is necessary in order to get a large population that can be successfully applied in vivo for complete tissue regeneration (Böcker et al. 2008).

Unfortunately, studies showed that human MSCs (hMSCs) undergo senescence-associated growth arrest when they are cultured in vitro; as they can give rise to a maximum of $24-40$ population doublings, and then their proliferation ability is over, this phenomenon is termed as replicative senescence (Böcker et al. 2008, Stenderup et al. 2003, DiGirolamo et al. 1999). This replicative senescence was found to be a result of telomere 
shortening of chromosomes during replication and division of the cells (Böcker et al. 2008, Baxter et al. 2004).

In vivo, telomere shortening has been found to be stopped by the action of the telomerase enzyme, which is a ribonuclear protein complex consisting of an integral RNA which serves as telomeric template and a catalytic subunit with reverse transcriptase activity (Counter et al. 1997, Lendvay et al. 1996, Zimmermann et al. 2003). Unfortunately, it has been found that hMSCs lack the telomerase activity in vitro, and thus result in the replicative senescence (Zimmermann et al. 2003, Simonsen et al. 2002).

The hTR gene encodes the RNA component of telomerase (Feng et al. 1995), whereas the TP1/TLP1 gene encodes a telomerase-associated protein of unknown function (Harrington et al. 1997, Nakayama et al. 1997). Unfortunately, attempts that were made to express these components in the cells did not always result in telomerase activity (Feng et al. 1995, Avilion et al. 1996, Harrington et al. 1997, Nakayama et al. 1997). Meyerson et al. managed to clone a human cDNA that encodes the putative telomerase catalytic protein subunit (Meyerson et al. 1997, Nakamura et al. 1997). This protein, which was originally named hEST2 (Meyerson et al. 1997) or hTRT (Nakamura et al. 1997) has been renamed TERT, according to the HUGO Nomenclature Committee of the Genome Database.

Based on these previous results, the attempts of in vitro immortalization of stem cells arose by the trial of introducing the gene coding for human TERT (hTERT) into the MSCs (Burns et al. 2005, Pfeifer et al. 2002). Neoplastic transformations were always found in most cases that used the gamma retroviruses as vectors for ectopic expression of hTERT into MSCs (Böcker et al. 2008, Burns et al. 2005, Pfeifer et al. 2002, Kohn 2007). That is the reason that made scientists think about the lentiviruses as vectors for the ectopic expression of the hTERT into the MSCs (Böcker et al. 2008). Unlike the retroviruses, no malignant transformations were observed in the MSCs after the ectopic expression of the hTERT using lentiviruses (Böcker et al. 2008, Docheva et al. 2010, Harley 2002), and thus, and a new cell line of 
immortalized MSCs was introduced, in which the cells are showing no malignant transformations, and do not undergo replicative senescence when they are cultured in vitro (Böcker et al. 2008).

Böcker et al. managed to produce an immortalized cell line of hTERT hMSCs, they gave it the name "SCP-1" (single cell picked clones) in which a single hMSC was picked under the light microscope at the $5^{\text {th }}$ passage after being transduced with the hTERT using the lentivirus, and the number 1 was given to distinguish this cell line from other 22 single picked clones cell lines (Böcker et al. 2008).

This study mainly concentrates on the immortalized SCP-1 cell line, and its ability to withstand culturing and the incubation with the bacteria that are involved in periodontitis, in order to support the idea of using the MSCs as a successful mean of stem cell based complete regeneration of damaged periodontium. 


\subsection{Bacteria involved in periodontitis}

As it has been stated before, periodontitis is a bacterial biofilm induced inflammatory disease that results in the destruction of the periodontal components including alveolar bone, cementum, gingiva, and PDL (Tan et al. 2009, Yanagita et al. 2011, Park et al. 2011, Hernandez et al. 2011). Periodontal disease is a result of the interaction of different etiologic factors, including the formation of bacterial biofilm in the subgingival microenvironment, dental health care, and the genetic susceptibility of the individual host (Offenbacher 1996, Kinane 2001). The major destruction of the periodontal apparatus associated with periodontitis results from the activation of the host's immune-inflammatory response to the bacterial virulence factors, mainly endotoxins (Offenbacher 1996, Kinane 2001, Hernandez et al. 2011). Although more than 400 different species of bacteria were found and detected in the oral cavity, only a limited number of bacteria have been found to act as periodontal pathogens (Salari and Kadkhoda 2004).

Many statistical studies have been carried out on a large variety of patients in order to detect and isolate the bacterial strains with the highest incidence in the periodontal pockets that are involved in chronic periodontitis (Salari and Kadkhoda 2004, Socransky et al. 2002, Colombo et al. 2009). Certain groups of Gram-negative bacteria have been found consistently in periodontal lesions, among these groups are, Actinobacillus actinomycetemcomitans, Porphyromonas gingivalis, Prevotella intermedia, Eikenella corrodens, Capnocytophaga species, and Spirochetes (Salari and Kadkhoda 2004, Haffajee and Socransky 1994, Mandell 1984, Colombo et al. 2009). For example, in the study that was carried out by Salari and Kadkhoda in 2004, bacterial samples were collected from the periodontal pockets of 203 patients (92 males and 111 females). Samples were cultured under anaerobic and capnophilic conditions. Isolated bacteria were found to be Actinobacillus actinomycetemcomitans (26.8\%), Porphyromonas gingivalis (21.9\%), Capnocytophaga sputigena (16.7\%), Eikenella corrodens (13.2\%), Prevotella 
intermedia (10.5\%), Prevotella disiens (3.1\%), Peptostreptococcus micros (2.9\%), Capnocytophaga gingivalis (2.2\%), Prevotella corporis (1.8\%), Peptostreptococcus magnus (1.3\%) and Fusobacterium nucleatum (0.4\%). No periodontopathogenic bacterial growth was observed in 14 of the samples (6.2\%) (Salari and Kadkhoda 2004). Another study by Mandell in 1984 reported that Eikenella corrodens and Actinobacillus actinomycetemcomitans have been found together in a certain type of periodontitis known as juvenile periodontitis (Salari and Kadkhoda 2004, Mandell 1984). Juvenile periodontitis (also known as aggressive periodontitis), is a certain clinical form of periodontal disease, which mainly occurs in individuals between the age of 12 and 20 years, and demonstrates a rapid aggressive loss of supporting alveolar bone around the first permanent molars and incisors (Salari and Kadkhoda 2004, Mandell 1984, Gajardo et al. 2005, Takeuchi et al. 2003). And therefore, this study concentrates mainly on these two types of bacteria (Actinobacillus actinomycetemcomitans and Eikenella corrodens) which were found to be highly involved in both chronic (the common type of periodontitis which is found in adults) and aggressive types of periodontitis (Salari and Kadkhoda 2004, Mandell 1984, Gajardo et al. 2005, Takeuchi et al. 2003). 


\subsubsection{Actinobacillus actinomycetemcomitans}

Actinobacillus actinomycetemcomitans is a highly pathogenic microorganism that is considered as the most important periodontal pathogen in both chronic and aggressive types of periodontitis (Salari and Kadkhoda 2004, Sakurai et al. 2007, de Graaff et al. 1989, Riggio et al. 1996). Actinobacillus actinomycetemcomitans is a Gram-negative bacterium, which is spherical or rod-shaped. It is a facultative anaerobe, which can grow under either aerobic or anaerobic conditions. Actinobacillus actinomycetemcomitans is a typical cause of periodontitis but it may also be related to systemic infections and arterial plaques (Lakio et al. 2003). It was first discovered by Klinger in 1912; who isolated this bacterium from cases of actinomycosis (de Graaff et al. 1989). Since this bacterium was frequently isolated in close association with Actinomyces israelii in actinomycotic lesions, Klinger proposed the name actinomycetemcomitans. The epithet "Actino" in the generic name Actinobacillus refers to the phenomenon that bacterial colonies grown on solid media produce an internal star-shaped morphology (de Graaff et al. 1989). Serological investigations led to the recognition of five different serotypes of Actinobacillus actinomycetemcomitans (from a to e) (Kaplan et al. 2001, Ebersole and Cappelli 1994, Perry et al. 1996). However, some studies have proposed the presence of another serotype ( $6^{\text {th }}$ serotype) of the Actinobacillus actinomycetemcomitans (serotype f) (Kaplan et al. 2001). As many other types of Gram-negative bacteria Actinobacillus actino-mycetemcomitans contains a lipopolysaccharide membrane. This lipopolysaccharide membrane contains a high molecular mass O-polysaccharide (O-PS) component. In this O-PS component, the immunodominant outer membrane antigen of the Actinobacillus actinomycetemcomitans is located, and that is what made a lot of scientists consider the lipopolysaccharide of the Actinobacillus actinomycetemcomitans as a very important virulence factor of this strain of bacteria (Lakio et al. 2003, Kaplan et al. 2001, Ebersole and Cappelli 1994). 


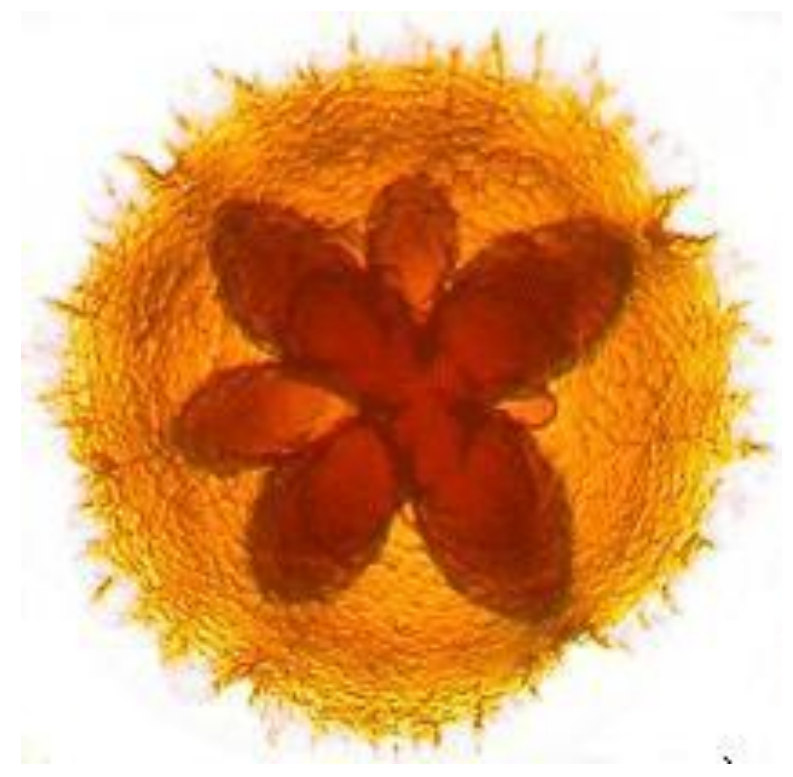

Figure 3: Image of Actinobacillus actinomycetemcomitans colony grown on selective agar (the star shaped morphology), taken from: http://microbewiki.kenyon.edu (2007). 


\subsubsection{Eikenella corrodens}

Eikenella corrodens is a Gram-negative facultative anaerobic bacterium that is found in the oral cavity, upper respiratory, and intestinal and genital tracts (Fujise et al. 2004, Chen CK et al. 1989, 1990, Chen CK and Wilson 1992). Eikenella corrodens is mainly considered as a periodontopathogen; as many statistical studies have revealed the large increase of its numbers in the periodontal pockets of the patients suffering from periodontitis (Salari and Kadkhoda 2004, Mandell 1984, Socransky et al. 2002, Colombo et al. 2009, Fujise et al. 2004). Eikenella corrodens can also act as a causative agent for some serious extraoral infections either alone as the only infective agent or in combination with other bacteria (Chen CK et al. 1990, Suwanagool et al. 1983). Some studies have considered Eikenella corrodens as a commensal bacterium in the oral cavity (Chen CK et al. 1990), as alone, it cannot produce periodontitis, unlike the Actinobacillus actinomycetemcomitans in the predominantly monoclonal periodontal infection with Actinobacillus actinomycetemcomitans. However, it is confirmed that Eikenella corrodens plays a strong synergistic role in multiclonal periodontal infections, especially together with Actinobacillus actinomycetemcomitans (Fujise et al. 2004, Chen CK et al. 1989, Mandell et al. 1987). Eikenella corrodens can colonize the subgingival sites much more efficiently than Actinobacillus actinomycetemcomitans, and thus decrease the defense ability of the gingival crevice against Actinobacillus actinomycetemcomitans (Fujise et al. 2004, Mandel et al. 1984). 


\subsection{Aim of the study}

This study mainly concentrates on the immortalized hTERT hMSCs, and their ability to withstand culturing and incubation with the bacteria that are involved in periodontitis, namely, Actinobacillus actinomycetemcomitans, and Eikenella corrodens, in order to elucidate the effects of bacteria on the immortalized MSCs.

\section{Individual aims:}

1. Observing the ability of the MSCs to withstand and survive culturing and incubation in the normal cell culture medium together with the viable periodontopathic bacteria after pushing them in a bacteriostatic state.

2. Investigating the capability of osteogenic differentiation of the MSCs after being cultured with periodontal pathogens.

3. Determining the future possibility of using MSCs as a successful means of stem cell based complete regeneration of damaged periodontium in periodontal diseases. 


\section{Materials and methods}

\subsection{Bacteria}

Bacteria were obtained with the help of the Microbiology Department, GeorgAugust-University, Göttingen.

Two main strains of bacteria were obtained:

- Actinobacillus actinomycetemcomitans (ATCC number 29522)

- Eikenella corrodens (ATCC number 23834).

As it has been stated before, both of them are facultative anaerobic strains of bacteria that are involved in periodontitis. Both strains of bacteria were intended for the first time to be grown in the same culture medium that is used for the normal cell culture; DMEM (Dulbecco's modified eagle's medium) (Gibco life technologies, USA) and 10 \%FBS (fetal bovine serum) (Invitrogen, USA) as a nutrient. After one week of incubation of bacteria in the normal cell culture medium growth of bacteria was then tested by streaking bacterial cell culture medium on blood agar plates. Streaking is a technique used with bacterial culturing on agar plates, in this technique a drop of the bacterial culture medium is carried on the end of a thin sterile loop of wire, which is known as an inoculator. The bacterial culture medium is then streaked across the surface of the blood agar leaving bacteria behind. A higher number of bacteria will be left behind at the beginning of the streak and a lower number will be left at the end. At a certain point during a successful streak, the number of bacteria deposited on the agar will be such that distinct individual colonies will grow which may be removed later for further culturing, using another sterile loop. After streaking of the bacteria on the blood agar plates, 
bacterial colonies were found to be growing after 24 hours in both Actinobacillus actinomycetemcomitans and Eikenella corrodens strains, indicating the ability of both of the bacterial strains to survive and grow in the cell culturing medium.

Bacterial growth was then intended to be stopped to put both strains of bacteria in a bacteriostatic state. This was managed by:

- Only $1 \%$ gentamycin in case of Eikenella corrodens.

- $1 \%$ gentamycin and 24 hours incubation of the bacteria in $-20^{\circ} \mathrm{C}$ in case of Actinobacillus actinomycetemcomitans.

After pushing the bacteria in the bacteriostatic state, bacterial growth on blood agar plates was then checked again to confirm the bacteriostatic state and no bacterial colonies were found to be growing out of the streaks indicating the stop of the bacterial growth. Bacteria in the DMEM were counted according to the McFarland standards and the exact counts of the bacterial colonies were obtained.

- Eikenella corrodens $9 \times 10^{5}$ bacterial colony/ $\mu$ l.

- Actinobacillus actinomycetemcomitans $22 \times 10^{5}$ bacterial colony/ $\mu$ l.

Bacteria were then diluted with normal DMEM to a concentration of 40 bacterial colony/ $\mu$, and were kept in $-20^{\circ} \mathrm{C}$ to maintain their bacteriostatic state. Undiluted bacteria were kept in $-80^{\circ} \mathrm{C}$.

McFarland turbidity standards are used to standardize the approximate number of bacteria in a liquid suspension (water, saline or liquid growth medium) by visual or spectrophotometric comparing the turbidity of a test suspension with the turbidity of a McFarland standard. The corresponding bacterial count in a comparable suspension is listed below each of the McFarland standards. McFarland standards are prepared by adding barium chloride to sulfuric acid to obtain a barium sulfate precipitate. By adjusting the volumes of these two reagents, standards of varying degrees of turbidity can be prepared to represent several different concentrations of bacteria. The standard most commonly used in the clinical microbiology laboratory for 
routine antimicrobial susceptibility tests is 0.5 which represents $1.5 \times 10^{8}$ bacteria/ml. McFarland standards are commercially available from several sources.

\subsection{Cell culture}

The cell line that has been used in this study is called SCP-1 cell line. Böcker et al. managed to produce an immortalized cell line of hTERT hMSCs, they gave it the name SCP-1, single cell picked clones, in which a single hMSC (purchased from Cambrex Corporation, East Rutherford, NJ, USA) was picked under the light microscope at the $5^{\text {th }}$ passage after being transduced with hTERT using lentivirus, and the number 1 was given to distinguish this cell line from other 22 single picked clones cell lines SCP.

The SCP-1 cell line was transferred to Prof. Dr. med. Nicolai Miosge, GeorgAugust-University as a gift from Prof. Dr. med. Matthias Schieker, Faculty of Medicine, München University, who participated in the production of the SCP1 cell line.

In this study, the MSCs were first incubated alone in the normal cell culture medium (DMEM, 10\% FCS, and 1\% gentamycin). Bacteriostatic Actinobacillus actinomycetemcomitans and Eikenella corrodens were then added to be incubated with the MSCs within the same flasks with the ratios of:

- 1 bacterial colony: 1 cell.

- 1 bacterial colony:100 cells.

- 2 bacterial colony: 1 cell.

- Controls without bacteria, just with the normal cell culture medium DMEM, 10\% FCS, $1 \%$ gentamycin. 
According to this, 7 different combinations were obtained:

1. AA1: MSCs with Actinobacillus actinomycetemcomitans with the ratio of $1: 1$.

2. AA100: MSCs with Actinobacillus actinomycetemcomitans with the ratio of $1: 100$.

3. AA2: MSCs with Actinobacillus actinomycetemcomitans with the ratio of 2:1.

4. EC1: MSCs with Eikenella corrodens with the ratio of 1:1.

5. EC100: MSCs with Eikenella corrodens with the ratio of 1:100.

6. EC2: MSCs with Eikenella corrodens with the ratio of 2:1.

7. Control: without bacteria, just normal cell culture medium.

The cells could not manage to survive the high ratio of 2:1, and thus AA2 and EC2 were lost, and eventually 5 different experiments were carried on:

1. $A A 1$

2. $A A 100$

3. EC1

4. EC100

5. Control 


\subsection{Determination of the growth and proliferation rates of the MSCs with different ratios of bacteria}

Immortalized MSCs were then cultured with both of the bacterial strains for 2 months starting from passage 77 . Cells were trypsinized, harvested, and counted (by the Cellometer) during the 2 months period of incubation. Passaging of the cells was carried out every 6 days, and the cell culture medium was changed with the bacteria every 3 days. Cell culturing started with the number of $8 \times 10^{5}$ cells per each flask (with a growth area of $75 \mathrm{~cm}^{2}$ ) at the beginning of each passage. After the incubation of the two strains of the bacteria with the immortalized MSCs for 2 months, growth curves were then blotted based on the cell counts that were obtained from the counting of the cells.

\subsubsection{The Cellometer Auto T4 (Nexcelom Bioscience)}

The Cellometer Auto T4 utilizes bright field imaging and pattern-recognition software to quickly and accurately identify and count individual cells. Cell count, concentration, diameter, and percentage of viability are automatically calculated and reported within 30 seconds. In comparison with the manual counting, the Cellometer Auto T4 is 10 times faster and more precise; as with a manual haemocytometer it would take at least 5 minutes to count $1 \times 10^{6}$ cells. Moreover, counting of live and dead cells is a much more complicated process, and sometimes it may take twice as long. The Cellometer Auto T4 cell counter is able to calculate the cell count, the concentration of live and dead cells, and the percentage of their viability in just 30 seconds. 


\section{Preparing the cells to be counted by the Cellometer:}

- Discard the cell culture medium with the bacteria by pouring them out of the flasks.

- Wash the flasks with 1xPBS (phosphate buffer saline) to ensure the total removal of the DMEM from the flasks, and to allow proper action of trypsin.

- Add $2.5 \mathrm{ml} 1 \mathrm{x}$ trypsin per flask, and leave it for 4 minutes to detach the cells from the bottom of the flasks.

- Tap on the sidewalls of the flasks to ensure the total detachment of the cells from the bottom of the flasks.

- Add 2.5ml DMEM to a $15 \mathrm{ml}$ Falcon tube.

- Add the trypsin with the cells to the $2.5 \mathrm{ml}$ DMEM in the $15 \mathrm{ml}$ Falcon tube to stop the action of the trypsin.

- Transfer the $15 \mathrm{ml}$ Falcon tube to the centrifuge (Eppendorf centrifuge 5810) and centrifuge with $1200 \mathrm{rpm}$ for 10 minutes, and then discard the supernatant solution to obtain the cell pellet.

- Resuspend the cell pellet in $1 \mathrm{ml} 1$ xPBS.

- Pipet $20 \mu \mathrm{l}$ of the cell-PBS solution on the counting plate.

- Use the Cellometer for counting the cells. The Cellometer indicates the count of the cells $/ \mathrm{ml}$, and that is why the cell pellet should be dissolved in $1 \mathrm{ml} 1 \mathrm{xPBS}$. 


\subsubsection{Fluorescence-activated cell sorting (FACS) analysis for ki-67}

The proliferation and the growth rates of the cells were also checked by the FACS analysis for the ki-67 protein.

\section{Intracellular staining of the cells with ki-67 for the FACS analysis:}

- Discard the cell culture medium with the bacteria by pouring them out of the flasks.

- Wash the flasks with $1 \times$ PBS to ensure the total removal of the DMEM from the flasks, and to allow proper action of the trypsin.

- Add $2.5 \mathrm{ml} 1 \mathrm{x}$ trypsin per flask, and leave it for 4 minutes to detach the cells from the bottom of the flasks.

- Tap on the sidewalls of the flasks to ensure the total detachment of the cells from the bottom of the flasks.

- Add $2.5 \mathrm{ml}$ DMEM to a $15 \mathrm{ml}$ Falcon tube.

- Add the trypsin with the cells to the $2.5 \mathrm{ml}$ DMEM in the $15 \mathrm{ml}$ Falcon tube to stop the action of the trypsin.

- Transfer the $15 \mathrm{ml}$ Falcon tube to the centrifuge (Eppendorf centrifuge 5810) and centrifuge with 1200 rpm for 10 minutes, and then discard the supernatant solution to obtain the cell pellet.

- Resuspend the cell pellet in $1 \mathrm{ml} 1 \mathrm{xPBS}$.

- Centrifuge with $1200 \mathrm{rpm}$ for 10 minutes, and then discard the supernatant solution to obtain the cell pellet.

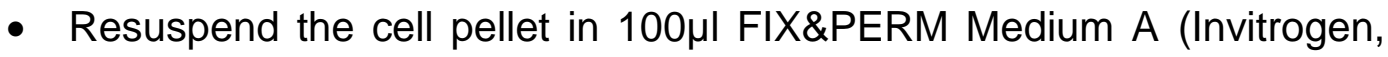
USA), and leave it for 20 minutes in room temperature for the fixation of the cells.

- After 20 minutes of incubation in room temperature, dilute with $3 \mathrm{ml}$ 1XPBS and then centrifuge again with 1200 rpm for 10 minutes.

- Discard the supernatant solution to obtain the cell pellet again. 


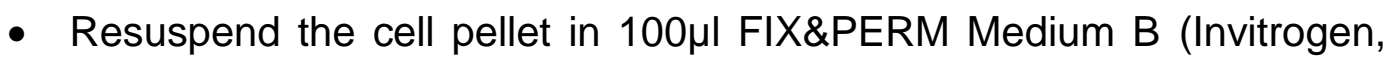
USA) for the permeabilization of the cells.

- Add $2 \mu \mathrm{l}$ of the ki-67 antibody (1:50 dilution) (Dako) to the previous solution and leave the whole mixture for 20 minutes in room temperature (not added to the iso and the negative controls).

- After 20 minutes of incubation in room temperature, dilute with $3 \mathrm{ml}$ 1xPBS, and then centrifuge with $1200 \mathrm{rpm}$ for 10 minutes.

- Discard the supernatant solution to obtain the cell pellet again.

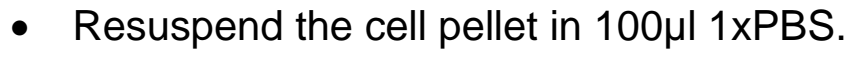

- Add $1 \mu$ l of the secondary antibody (anti-mouse IgG FITC) (KPL, USA) to the previous solution, and leave the whole mixture for 20 minutes in room temperature (not added to the negative control).

- After 20 minutes of incubation in room temperature, dilute with $3 \mathrm{ml}$ $1 \times$ PBS, and then centrifuge with $1200 \mathrm{rpm}$ for 10 minutes.

- Discard the supernatant solution to obtain the cell pellet again.

- Resuspend the cell pellet in 1xPBS.

- The sample is then analyzed by the FACS analysis apparatus (FACScan (BD) Becton Dickinson). 


\subsection{Testing the MSCs for stem cell markers after incubation with bacteria}

\subsubsection{Testing the MSCs for the stem cell markers (CD44, CD29, CD166, and CD105) with the help of immunohistochemistry after 3 weeks of incubation with bacteria}

After 3 weeks of incubation of the cells with the bacteria, cells were tested for the stem cell markers CD44, CD29, CD166, and CD105 to confirm their stemness after the period of the incubation. This was done according to the following protocol:

- Cells (1000 cells/well) are cultured and incubated with the bacteria in 24 well plates till they are $80 \%$ confluent.

- Discard the cell culture medium using a small suction tip.

- Wash one time with $1 \times$ PBS $1 \mathrm{ml} /$ well.

- Remove the $1 \times$ PBS using a small suction tip.

- Add $70 \%$ Ethanol $\left(1 \mathrm{ml} /\right.$ well) from $4^{\circ} \mathrm{C}$ for 10 minutes for fixation of the cells.

- Wash with $1 \times$ PBS for 2 or 3 times.

- Add the primary antibody with the concentration of 1:50 diluted in 1xPBS (for each well $300 \mu \mathrm{l}$ of the diluted antibody are required), thereafter, the cells are incubated with the antibody for 60 minutes in $37^{\circ} \mathrm{C}$ (add 1xPBS only for the iso and negative controls).

- Discard the antibody using a small suction tip.

- Wash twice with 1 XPBS.

- Add the secondary antibody anti-mouse IgG FITC (KPL, USA) with the concentration of 1:100 diluted in 1xPBS, for each well $300 \mu \mathrm{l}$ of diluted 
antibody are required, then the cells are incubated with the $2^{\text {ry }}$ antibody for 30 minutes in $37^{\circ} \mathrm{C}$. This step is done only for the uncoupled antibodies (CD166), and the isocontrol, while for the coupled antibodies (CD44, CD 105, and CD29), and the negative control only $1 \mathrm{xPBS}$ is added.

- Wash twice with 1xPBS.

- For counterstaining the DAPI is added with the concentration of 1:1000

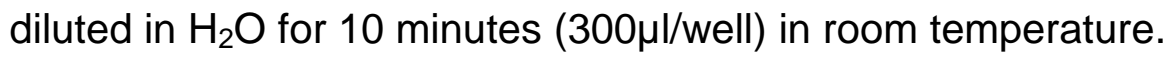

- Wash twice with 1xPBS.

- Seal with a glass cover.

\subsubsection{Testing the MSCs for the stemness markers (Klf4 and C-myc) genes and their associated effects on the osteogenic genes (Runx2 and Col1) using the real time PCR after 2 months of incubation with bacteria}

\subsubsection{Isolation of the RNA from the MSCs}

An RNeasy isolation kit (QIAGEN, Hamburg) has been applied for these procedures.

- Discard the cell culture medium with the bacteria by pouring them out of the flasks.

- Wash the flasks with 1xPBS to ensure the total removal of the DMEM from the flasks, and allow proper action of the trypsin.

- Add $2.5 \mathrm{ml} 1 \mathrm{x}$ trypsin per flask, and leave it for 4 minutes to detach the cells from the bottom of the flasks. 
- Tap on the sidewalls of the flasks to ensure the total detachment of the cells from the bottom of the flasks.

- Add 2.5ml DMEM in 15ml Falcon tube.

- Add the trypsin with the cells on the $2.5 \mathrm{ml}$ DMEM to the $15 \mathrm{ml}$ Falcon tube to stop the action of the trypsin.

- Transfer the $15 \mathrm{ml}$ Falcon tube to the centrifuge (Eppendorf centrifuge 5810) and centrifuge with 1200 rpm for 10 minutes, and then discard the supernatant solution to obtain the cell pellet.

- Resuspend the cell pellet in $1 \mathrm{ml} 1 \mathrm{xPBS}$, and put the solution in a $1.5 \mathrm{ml}$.

- Transfer the Eppendorf cups to the centrifuge (Eppendorf centrifuge 5415R, Germany), and centrifuge with 2.3 rpm for 10 minutes, and then discard the supernatant solution to obtain the cell pellet in the 1.5 Eppendorf cups.

- Prepare the RLT buffer (QIAGEN, Hamburg) by adding:

A. $350 \mu$ of RLT lysis buffer (QIAGEN, Hamburg) with

B. $3.5 \mu \mathrm{l}$ of $\beta$-Mercaptoethanol (2-Mercaptoethanol)

This amount is used for a cell pellet containing from 500 till $1,000,000$ cells, and if the cells are more than $1,000,000$ cells, then the amount of the RLT buffer should be doubled.

- Add the $350 \mu \mathrm{LLT}$ buffer onto the cell pellet, and then vortex properly to allow the solution to be in contact with all of the cells, and leave it for 2 minutes to give time for the lysing action of the RLT buffer.

- Apply the whole solution of the cells and the RLT buffer in a shredder vial (QIAGEN, Hamburg), the shredder separates the damaged cell skeleton from the contents of the cells.

- Transfer the shredder vial with the solution to the centrifuge (Eppendorf centrifuge 5415R), then centrifuge with full speed for 2 minutes, then discard the filter (purple part) of the shredder as the cell contents with the solution would have been passed through the filter to the tube part of the shredder.

- Add $350 \mu$ l of $70 \%$ ethanol to the previous solution in the tube part of the shredder. 
- Take the whole solution from the tube of the shredder, and pipet it onto an RNA easy column, and then centrifuge with the Eppendorf centrifuge $5415 \mathrm{R}$, with $10.000 \mathrm{rpm}$ for $15-30$ seconds to separate the RNA from the rest of the contents of the cells.

- Discard the supernatant solution in the tube of the RNA easy column, as the RNA component will be trapped by the filter of the RNA easy column (the pink part).

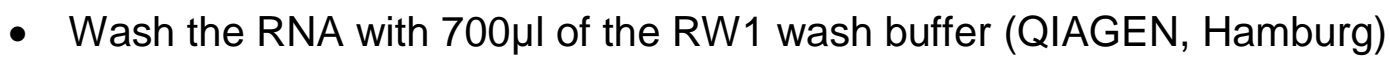
by pipetting the buffer in the RNA easy tube. It is important in this step not to touch the filter of the RNA easy tube with the pipet as it traps the RNA.

- Centrifuge with $10,000 \mathrm{rpm}$ for $15-30$ seconds, and then discard the solution in the tube part of the RNA easy column.

- Wash another time with 500 $\mathrm{\mu l}$ of the RPE buffer (QIAGEN, Hamburg) and centrifuge with $10,000 \mathrm{rpm}$ and then get rid of the solution (this step is repeated twice).

- Centrifuge with the full speed for 1-2 minutes to nearly dry the RNA from the solution.

- Take the filter (pink part) of the RNA easy column with the isolated RNA trapped in it, and put it on the top of an RNA free safe lock tube (QIAGEN, Hamburg).

- Add $30 \mu \mathrm{l}$ of DEPC water in the filter (pink part) of the RNA easy column.

- Leave the water for 5 minutes at room temperature.

- Centrifuge for 1 minute with 10,000 rpm, the centrifugation will allow the RNA with the DEPC water to pass through the filter into the RNA free tube.

- Use the NanoDrop apparatus (PeqLab) to determine the amount of the nucleic acid that is isolated from the cells. 


\subsubsection{Transcription of the RNA to cDNA}

In this procedure a reverse transcription kit (QIAGEN, Hamburg) is required.

Quantiscript reverse transcription procedures:

- Prepare the master mixture (always $14 \mu \mathrm{l}$ ) in a 1.5ml Eppendorf cup.

- The master mixture is composed of:

- $2 \mu \mathrm{l}$ gDNA-wipeout Buffer (QIAGEN, Hamburg).

- $1 \mu \mathrm{l}$ of the isolated RNA mixture (up to $1 \mu \mathrm{g} / \mu \mathrm{l}$ and minimum $200 \mathrm{ng} / \mu \mathrm{l})$.

- $11 \mu \mathrm{l}$ RNase free water (QIAGEN, Hamburg).

Both the RNA and the RNase free water are variable according to the amount of the RNA which is isolated, so if the amount is less than $200 \mathrm{ng} / \mu \mathrm{l}$, the RNA mixture should be increased and the RNase free water should be decreased in an inverse relationship, so that both of them would not exceed $12 \mu \mathrm{l}$ and thus the master mixture would not exceed $14 \mu \mathrm{l}$.

- Heat the master mixture $(14 \mu \mathrm{l})$ at $42{ }^{\circ} \mathrm{C}$ for 2 minutes in the Thermomixer (Eppendorf thermomixer comfort, Germany)

- Remove the master mixture $(14 \mu \mathrm{l})$ from the Thermomixer and then add to it:

- $4 \mu \mathrm{l}$ RT-Buffer (QIAGEN, Hamburg).

- $1 \mu$ reverse transcriptase enzyme (QIAGEN, Hamburg).

- $1 \mu \mathrm{R}$ RT-primers (QIAGEN, Hamburg).

And thus, eventually a mixture of $20 \mu$ is obtained.

- Transfer the $20 \mu \mathrm{l}$ mixture to the Thermomixer at $42^{\circ} \mathrm{C}$ for 15 minutes to start the reaction of the reverse transcriptase enzyme.

- Finally, put the $20 \mu \mathrm{l}$ mixture in the Thermomixer at $95^{\circ} \mathrm{C}$ for 3 minutes to stop the reverse transcriptase action. 
For the cDNA to be used for the PCR it should be diluted in DEPC water to the concentration of $1 \mathrm{cDNA} n \mathrm{ng} / \mu \mathrm{l}$.

\subsubsection{Preparing the sample for the PCR machine}

The Klf4, and the C-myc primers were designed with the help of primer3 program, (http://frodo.wi.mit.edu/primer3/), and they were manufactured by Eurofins MWG Operon company and then their sequences were checked in the SeqLab Laboratories. Real time PCR was performed using the Eppendorf realplex ${ }^{2}$ Mastercycler epgradient S PCR machine. $\beta 2 \mathrm{M}$ was used as a housekeeping gene.

The following primers were used

\begin{tabular}{|l|l|l|l|}
\hline $\begin{array}{l}\text { Primer } \\
\text { name }\end{array}$ & $\begin{array}{l}\text { Forward } \\
\left(5^{\prime} \rightarrow 3^{\prime}\right)\end{array}$ & $\begin{array}{l}\text { Reverse } \\
\left(5^{\prime} \rightarrow 3^{\prime}\right)\end{array}$ & $\begin{array}{l}\text { Annealing } \\
\text { temperature } \\
\left({ }^{\circ} \mathrm{C}\right)\end{array}$ \\
\hline B2M & tgctgtctccatgttgatgtatct & tctctgctccccacctctaa & $61^{\circ} \mathrm{C}$ \\
\hline Col1 & ttcccccagccacaaagagtc & cgtcatcgcacaacacct & $61^{\circ} \mathrm{C}$ \\
\hline KIf4 & ccaccggacctacttact & ccccaaagtcaacgaaga & $57.9^{\circ} \mathrm{C}$ \\
\hline C-myc & cggtttcggggcttatc & cttgctcgggtgttgtaag & $57.9^{\circ} \mathrm{C}$ \\
\hline
\end{tabular}




\begin{tabular}{|l|l|l|l|}
\hline Runx2 & ttccagaccagcagcactc & cagcgtcaacaccatcatt & $63^{\circ} \mathrm{C}$ \\
\hline
\end{tabular}

\section{Preparing the sample for real time PCR:}

- First the master mixture is prepared. The master mixture is composed of (for each well in the PCR plate) :

- $2 \mu \mathrm{l}$ of the primer.

- $4.5 \mu$ l SYBR green (Invitrogen, USA) which is the fluorescence marker of the amplified cDNA.

- $2.5 \mu \mathrm{l}$ DEPC water (RNase free water).

- The $9 \mu$ l of the master mixture are first added in each well in the PCR plate then the $1 \mu$ of the cDNA sample that is meant to be amplified is added to the master mixture in each well.

- Finally a mixture of $10 \mu$ l is obtained per each well in the PCR plate.

The PCR system that was performed works in triplets (three times) for three successive days; in order to insure the accuracy of the resulting cycle threshold (Ct) values, and to be sure that the results are totally free of any technical or handling errors. The resulting $9 \mathrm{Ct}$ values were then analyzed with the Pfaffl model, which is a mathematical model for relative quantification of the target gene in comparison to a reference (housekeeping) gene (Pfaffl 2001).

The $\mathrm{Ct}$ value is defined as the number of cycles required for the fluorescent signal (by the SYBR green coupling to the amplified cDNA) to cross the background threshold (exceeds background level). The $\mathrm{Ct}$ values are inversely proportional to the amount of target CDNA in the sample (the lower the Ct value the greater the amount of target cDNA in the sample). 


\subsection{Osteogenic differentiation of the MSCs after the two months of incubation with bacteria}

After 2 months of incubation of the cells with bacteria, the cells were then transferred to the osteogenic differentiation medium. Cells were divided into 2 main groups:

1. Cells which were osteodifferentiated with mesenchymal stem cell osteogenic differentiation medium (Promocell $\mathrm{GmbH}$, Heidelberg, Germany). The cells in this group were given the names (O-AA1-, O-AA100-, O-EC1-, O-EC100-, and O-control).

2. Cells which were osteodifferentiated with mesenchymal stem cell osteogenic differentiation medium and with the addition of the bacteria to the osteogenic differentiation medium with the same previous ratios of incubation (1:1 and 1:100). The cells in this group were given the names $(\mathrm{O}-\mathrm{AA} 1+\mathrm{O}-\mathrm{AA} 100+, \mathrm{O}-\mathrm{EC} 1+$, and $\mathrm{O}$ EC100+).

- (O-AA1+) with 1 bacterial colony (AA):1 cell.

- (O-AA100+) with 1 bacterial colony (AA):100 cells.

- (O-EC1+) with 1 bacterial colony (EC):1 cell.

- (O-EC100+) with 1 bacterial colony (EC):100 cells. 
3. Thus finally 9 different cell experiments were obtained:

- 1. O-AA1+

2. O-AA100+

3. O-EC1+

4. O-EC100+

- 5. O-AA1-

6. O-AA100-

7. O-EC1-

8. O-EC100-

9. O-control osteogenic differentiation medium with bacteria (+). osteogenic differentiation medium

without bacteria (-).

\subsection{Testing the MSCs for the osteogenic differentiation after the incubation with the osteogenic differentiation medium}

\subsubsection{Alkaline phosphatase staining}

After 8 days of cell incubation with the osteogenic differentiation medium, cells were checked for alkaline phosphatase enzyme activity. An alkaline phosphatase staining kit (Sigma-Aldrich, Steinheim, Germany) was applied for the alkaline phosphatase staining procedures.

a) Preparing the alkaline staining mixture:

Add $0.1 \mathrm{ml}$ sodium nitrate solution on $0.1 \mathrm{ml}$ FBB-alkaline solution in a $15 \mathrm{ml}$ Falcon tube, and then both solutions should be mixed properly and left for 2 minutes to allow the reaction between them to start. After 2 minutes, add $4.5 \mathrm{ml} \mathrm{H}_{2} \mathrm{O}$ (room temperature), and $0.1 \mathrm{ml}$ naphthol AS-BI alkaline solution 
onto the previous solutions in the Falcon tube and then the whole mixture should be mixed properly.

\section{b) Preparing the fixation solution:}

Add $2.5 \mathrm{ml}$ citrate solution to $6.5 \mathrm{ml}$ acetone and $0.8 \mathrm{ml} 37 \%$ formaldehyde solution, and then the whole mixture should be mixed properly. The mixture is put in the refrigerator $\left(4^{\circ} \mathrm{C}\right)$ to be stable for approximately 4 weeks later.

\section{c) The Permeability solution:}

0.125 gram Triton $\mathrm{x}-100$ diluted in $50 \mathrm{ml} 1 \mathrm{xPBS}$.

\section{d) The procedures:}

- Cells are washed with 1 XPBS twice for 15 minutes each.

- Cells are fixed with the fixation solution for 30 seconds.

- Wash the cells for 45 seconds with 1 xPBS.

- Add the permeability solution (the triton) for 3 minutes in room temperature.

- Wash the cells many times with $\mathrm{H}_{2} \mathrm{O}$ until the triton is completely removed.

- Stain the cells with the alkaline staining solution by putting it for 15 30 minutes at $37^{\circ} \mathrm{C}$ in a light protected place.

- Wash the cells for 2 minutes with $\mathrm{H}_{2} \mathrm{O}$.

- Use the neutral red solution for counter staining for 2 minutes in room temperature.

- Wash with tap water.

- Leave the cells to dry in the air. 
- Cover the slide with glass cover.

\subsubsection{Testing the MSCs for the osteogenic differentiation with the immunocytochemistry}

After 12 days of incubation with the osteogenic differentiation medium, the cells were checked for the osteopontin (an extracellular structural protein, and thus an imporant component of the bone, also it acts as an indicator of the bone turnover) using immunocytochemistry.

- Cells (1000 cells/well) are cultured and incubated with the osteogenic differentiation medium in 24 well plates till they are $80 \%$ confluent.

- Discard the osteogenic differentiation medium using a small suction tip.

- Wash one time with $1 \times$ PBS $1 \mathrm{ml} /$ well.

- Remove the 1xPBS using small suction tip.

- Add $70 \%$ Ethanol ( $1 \mathrm{ml} /$ well) from $4^{\circ} \mathrm{C}$ for 10 minutes for fixation of the cells.

- Wash with 1 xPBS for 2 or 3 times.

- Add the osteopontin antibody with the concentration of 1:50 diluted in 1xPBS (for each well $300 \mu \mathrm{l}$ of diluted antibody are required), then the cells are incubated with the osteopontin antibody for 60 minutes in $37^{\circ} \mathrm{C}$ (use $1 \mathrm{xPBS}$ only for the iso and negative controls).

- Discard the antibody using a small suction tip.

- Wash twice with 1xPBS.

- Add the secondary antibody, anti-mouse IgG FITC (KPL, USA), with the concentration of 1:100, diluted in 1xPBS (for each well $300 \mu \mathrm{l}$ of diluted antibody are required), then the cells are incubated with the $2^{\text {ry }}$ antibody for 30 minutes in $37^{\circ} \mathrm{C}$ (for the negative control no secondary antibody is added, only 1 xPBS is added).

- Wash twice with $1 \times$ PBS. 
- For counterstaining DAPI is added with a concentration of 1:1000 diluted in $\mathrm{H}_{2} \mathrm{O}$ for 10 minutes (300 $\mathrm{\mu l} /$ well).

- Wash twice with 1 xPBS.

- Seal with a glass cover.

\subsubsection{Testing the MSCs for the degree of osteogenic differentiation using the real time PCR (testing the expression of the Runx 2 and Col1 after osteogenic differentiation)}

After 2 weeks of incubation of the MSCs with the osteogenic differentiation medium, cells were tested for the degree of osteogenic differentiation with the help of the real time PCR to test for Runx2 and Col1 expression. $32 \mathrm{M}$ was applied as a housekeeping gene.

RNA was isolated from the cells and then transcripted into CDNA as stated before, then real time PCR was performed with the help of Eppendorf realplex2 Mastercycler epgradient S PCR machine. 


\section{Results}

\subsection{Bacterial growth in the normal cell culture medium}

After one week of incubation of the bacteria in the normal cell culture medium, growth of the bacteria was then observed by streaking the bacterial cell culture medium on blood agar plates. In both of the cases, Actinobacillus actinomycetemcomitans and Eikenella corrodens, bacterial colonies appeared to be growing out of the streaks. This was the first evidence of successful growth of periodontal pathogens in the normal cell culturing medium (Figure 4).

After the addition of $1 \%$ gentamycin in order to stop bacterial growth to reach a bacteriostatic state, growth was then checked again by streaking the bacterial cell culture medium again on the blood agar plates. Here, each strain of the two strains of bacteria had a different response to the $1 \%$ gentamycin.

- In the case of Eikenella corrodens, no bacterial colonies were found to be growing out of the streaks indicating the total stop of the bacterial growth, and that the bacteria were now in the bacteriostatic state (Figure 5).

- In the case of Actinobacillus actinomycetemcomitans, there were still some bacterial colonies growing out of the streaks indicating that the bacteria were still viable. In order to stop the bacterial growth completely; bacteria were incubated for 24 hours in $-20^{\circ} \mathrm{C}$, and then checked again for their growth. After one day of incubation in $-20{ }^{\circ} \mathrm{C}$, the bacterial cell culture medium was streaked again on the blood agar plates, but no bacterial colonies were found to be growing out of the 
streaks indicating a complete stop of the growth of the bacteria, and that the bacteria are in the bacteriostatic state.

After the complete stop of the bacterial growth, bacterial colonies were then counted with the McFarland standards, and an exact count was obtained for each strain.

- For the Eikenella corrodens $9 \times 10^{5}$ bacterial colony $/ \mu \mathrm{l}$.

- For the Actinobacillus actinomycetemcomitans $22 \times 10^{5}$ bacterial

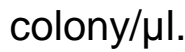

bacterial colonies

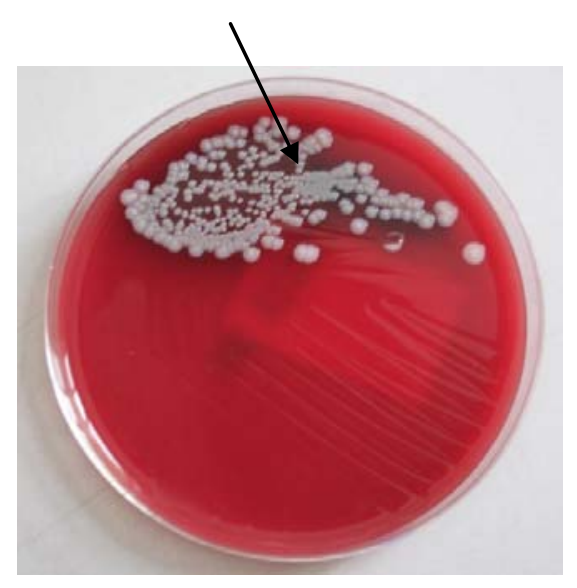

Figure 4

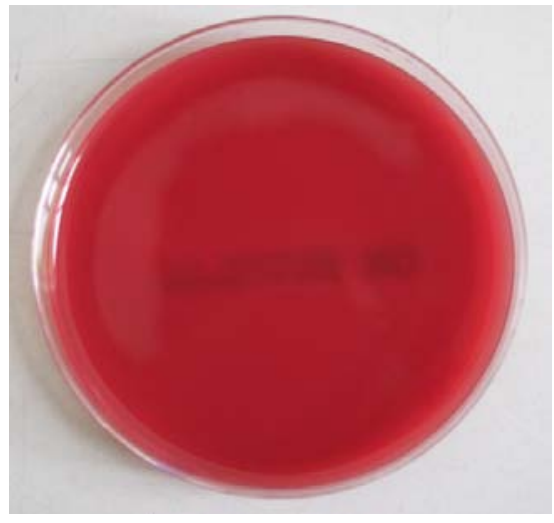

Figure 5

Figure 4: Blood agar plate showing Eikenella corrodens bacterial growth after one week of incubation within the cell culture medium. Figure 5: Blood agar plate showing no Eikenella corrodens growth after the addition of $1 \%$ gentamycin indicating a bacteriostatic state. 


\subsubsection{The growth rate of the MSCs during the period of two months of the incubation with the bacteria}

As it is has been stated before in the materials and methods section, cells were incubated with the Actinobacillus actinomycetemcomitans and Eikenella corrodens bacteria (Figure 6) with three different ratios (1:1, 2:1, and 1:100) for each type of bacteria, and a control without bacterial incubation, thus finally 7 different cell combinations were obtained (AA1, AA2, AA100, EC1, EC2, EC100, and Control).

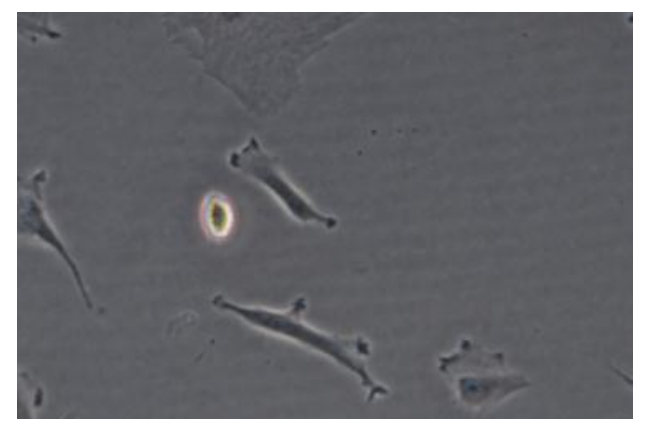

Figure 6: Bacteria incubated with the cells.

In the cases of AA2 and EC2 the cells could not withstand the high bacterial ratio and all of the cells died within:

- 5 days in the case of AA2.

- 7 days in the case of EC2. 
Thus, eventually only 5 different experiments were carried on:

1. $A A 1$

2. $A A 100$

3. EC1

4. EC100

5. Control

\subsubsection{Counting of the cells with the Cellometer during the incubation with the bacteria}

During a period of 2 months, cells were passaged and counted regularly with the Cellometer every 6 days. The results that were obtained from the Cellometer were a little bit fluctuating, this may be due to the fact of the fluctuating nature of the proliferation of the stem cells as it is stated by Watt and Hogen in 2000 in the Science journal that "although a stem cell has high self-renewal capacity, it may actually divide relatively infrequently" (Watt and Hogen 2000). However, in general, it can be observed that in most of the counts of the cells incubated with the Eikenella corrodens (about $70 \%$ of the cell counts, in the cases after $6,18,30,36,42,54$, and 60 days), and in all of the counts of the cells (100\%) incubated with the Actinobacillus actinomycetemcomitans it was interestingly found that the cells that were incubated with the higher numbers (ratios) of bacteria, showed higher proliferation and growth rates than those incubated with the lower numbers (ratios) of bacteria. Moreover, it can be generally stated that the MSCs in most of the counts of the cells (about $70 \%$ of the cell counts in the cases after $6,12,18,24,36,42$, and 54 days) incubated with the higher numbers (ratios) (1:1) of Eikenella corrodens exhibited higher proliferation and growth rates than those incubated without bacteria (controls). More interestingly, almost all of the MSCs in the counts of the cells (about $90 \%$ of the cell counts in the cases after $6,18,24,30,36,42,48,54$ and 60 days) incubated with the 
higher numbers (ratios) (1:1) of Actinobacillus actinomycetemcomitans exhibited higher proliferation and growth rates than those incubated without bacteria (controls) (Table 1, Figure 7).

As this contradicts common sense at first glance, further extensive experiments were carried out to enforce the previous results:

- Regarding the time interval of the passaging and the cell counting, cells were passaged and counted with another time interval (every 4 days) over a period of 50 days, and the same relations were obtained between the different ratios for both types of bacteria.

- Regarding the cell number at the beginning of each passage, 2 parallel experiments were carried out:

1. Starting with the number of $8 \times 10^{5}$ cells per each flask (with growth area of $75 \mathrm{~cm}^{2}$ ).

2. Starting with the number of $2.5 \times 10^{5}$ cells per each flask (with growth area of $25 \mathrm{~cm}^{2}$ ), and for both cases, relations between cell counts were consistent with the previously obtained results.

- Regarding the methodology of cell counting, the counts that were obtained from the Cellometer, were confirmed randomly by recounting them with the manual haemocytometer.

- Regarding the possibility of cross contamination of the controls during passaging, all flasks were discarded and a new set of flasks were used after each passage. 
cell line 6 days 12 days 18 days 24 days 30 days 36 days 42 days 48 days 54 days 60 days $\begin{array}{lllllllllll}\text { EC1 } & 1040000 & 1100000 & 1020000 & 794000 & 544000 & 2720000 & 2280000 & 1113000 & 2900000 & 1810000\end{array}$ \begin{tabular}{l|llllllllll} 
EC100 & 652000 & 1130000 & 823000 & 961000 & 514000 & 2260000 & 1780000 & 1120000 & 1500000 & 1660000
\end{tabular} $\begin{array}{llllllllllll}\text { AA1 } & 865000 & 879000 & 893000 & 776000 & 1240000 & 2060000 & 2330000 & 1390000 & 2900000 & 3370000\end{array}$ $\begin{array}{lllllllllll}\text { AA100 } & 840000 & 691000 & 722000 & 731000 & 694000 & 1500000 & 1340000 & 1114000 & 1500000 & 1050000\end{array}$ Control $\quad \begin{array}{llllllllll}589000 & 959000 & 814000 & 629000 & 894000 & 1330000 & 2210000 & 1300000 & 1380000 & 1810000\end{array}$

Table 1: Showing the cell counts (with the Cellometer) of the different cell experiments (AA1, AA100, EC1, EC100, and control) obtained during a period of 2 months of incubation with bacteria with 6 day-time interval between each count. 


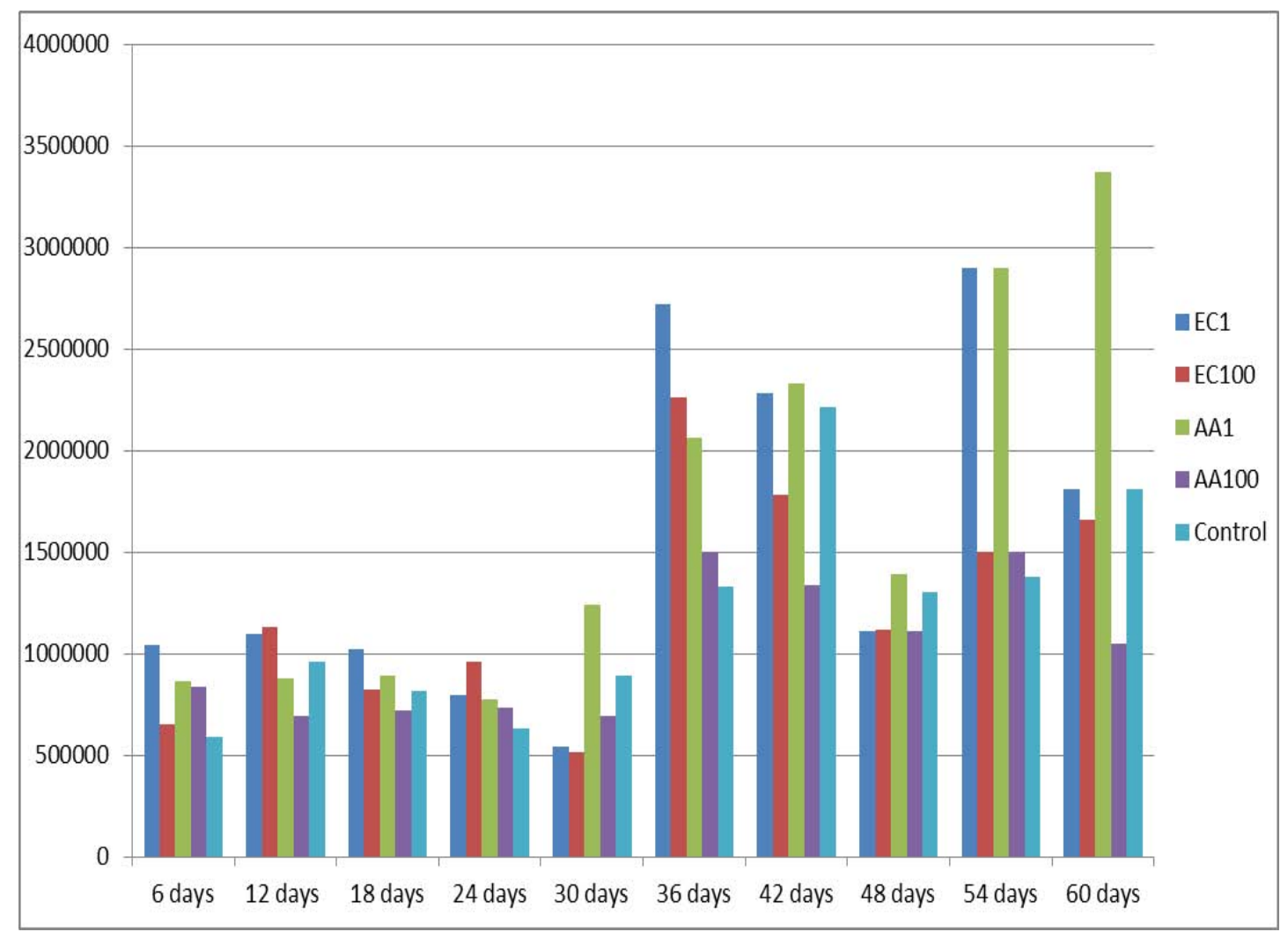

Figure 7: Cell counts (obtained from the Cellometer) of the different cell experiments (AA1, AA100, EC1, EC100, and control) obtained during a period of 60 days of incubation with bacteria, with 6 day-time interval between each count. 


\subsubsection{FACS (fluorescence-activated cell sorting) analysis for ki-67}

Results that were obtained from the FACS analysis of the cells for ki-67 (which is a nuclear protein that is associated with and may be necessary for cellular proliferation) enforced the results that were obtained by the cell counting with the Cellometer. It was found that the MSCs that were incubated with the higher numbers (ratios) of the bacteria (1:1), showed a higher percentage of positive cells for the ki-67 than those incubated with the lower numbers (ratios) of the bacteria (1:100). Moreover, tendency was seen that the cell experiments incubated with the higher numbers (ratios) of bacteria (1:1) also exhibited a higher percentage of positive cells for the ki-67 than those incubated without bacteria (controls). These results were found to be consistent with the both strains of bacteria (Tables 2, 3, and 4, Figures 8, 9a, 9b, 9c, 10a, 10b, 11a, and 11b).

FACS analysis of the MSCs for the ki-67 has been repeated three successive times to insure the previously obtained results. There was a gap period of one week between each FACS analysis to allow the cells to proliferate and reach a reasonable number that would be sufficient for each FACS analysis. This means that, it is not expected that the percentage of the positive cells for the ki-67 will increase with the increase of the period of incubation with bacteria, but what is expected is that the relations between the different cell experiments should be consistent and persistent within the 3 runs of the FACS analyses.

The fluctuating nature of the cell growth and proliferation, as well as the one week time interval between each FACS analysis, may be regarded as good explanations for the high values of the standard deviations of the averages which were obtained from the three successive FACS analyses. However, the results that were obtained from the three FACS analyses, regarding the relations between the different cell experiments and the controls, were found 
to be consistent with each other, and with those results obtained from the cell counting with the Cellometer (Figure 8).

- The first FACS analysis:

\begin{tabular}{|l|l|l|l|}
\hline $\begin{array}{l}\text { Cell } \\
\text { experiment }\end{array}$ & $\begin{array}{l}\text { Total positive \% } \\
\text { for the ki-67 }\end{array}$ & $\begin{array}{l}\text { Total positive \% } \\
\text { for the isocontrol } \\
\left(2^{\text {ry }} \text { antibody }\right. \\
\text { only) }\end{array}$ & $\begin{array}{l}\text { Total positive } \\
\% \text { after omitting } \\
\text { the of the } 2^{\text {ry }} \\
\text { antibody }\end{array}$ \\
\hline AA1 & $39.46 \%$ & $1.49 \%$ & $37.97 \%$ \\
\hline AA100 & $26.26 \%$ & $1.45 \%$ & $24.81 \%$ \\
\hline EC1 & $35.53 \%$ & $1.53 \%$ & $34 \%$ \\
\hline EC100 & $28.50 \%$ & $1.26 \%$ & $27.24 \%$ \\
\hline Control & $19.13 \%$ & $1.36 \%$ & $17.77 \%$ \\
\hline
\end{tabular}

Table 2: Showing the MSCs positive percentage for ki-67 after sorting with the FACS analysis (the first FACS analysis), after 60 days of incubation with bacteria. 
- The second FACS analysis:

\begin{tabular}{|l|l|l|l|}
\hline $\begin{array}{l}\text { Cell } \\
\text { experiment }\end{array}$ & $\begin{array}{l}\text { Total positive \% } \\
\text { for the ki-67 }\end{array}$ & $\begin{array}{l}\text { Total positive \% } \\
\text { for the isocontrol } \\
\left(2^{\text {ry }} \text { antibody }\right. \\
\text { only) }\end{array}$ & $\begin{array}{l}\text { Total positive \% } \\
\text { after omitting } \\
\text { the \% of the 2y } \\
\text { antibody }\end{array}$ \\
\hline AA1 & $64.50 \%$ & $2.67 \%$ & $61.83 \%$ \\
\hline AA100 & $52.87 \%$ & $2.13 \%$ & $50.74 \%$ \\
\hline EC1 & $46.12 \%$ & $2.00 \%$ & $44.12 \%$ \\
\hline EC100 & $41.05 \%$ & $3.52 \%$ & $37.53 \%$ \\
\hline Control & $33.67 \%$ & $1.06 \%$ & $32.61 \%$ \\
\hline
\end{tabular}

Table 3: Showing the MSCs positive percentage for ki-67 after sorting with the FACS analysis (the second FACS analysis), after 67 days of incubation with the bacteria.

- The third FACS analysis:

\begin{tabular}{|l|l|l|l|}
\hline $\begin{array}{l}\text { Cell } \\
\text { experiment }\end{array}$ & $\begin{array}{l}\text { Total positive \% } \\
\text { for the ki-67 }\end{array}$ & $\begin{array}{l}\text { Total positive \% } \\
\text { for the } \\
\text { isocontrol } \\
\text { antibody only) } \\
\left(2^{\text {ry }}\right.\end{array}$ & $\begin{array}{l}\text { Total positive \% } \\
\text { after omitting } \\
\text { the of the 2y } \\
\text { antibody }\end{array}$ \\
\hline AA1 & $66.63 \%$ & $6.77 \%$ & $59.86 \%$ \\
\hline AA100 & $58.63 \%$ & $1.33 \%$ & $57.3 \%$ \\
\hline EC1 & $77.12 \%$ & $5.19 \%$ & $71.93 \%$ \\
\hline EC100 & $78.01 \%$ & $6.59 \%$ & $71.42 \%$ \\
\hline Control & $57.73 \%$ & $3.69 \%$ & $54.04 \%$ \\
\hline
\end{tabular}

Table 4: Showing the MSCs positive percentage for ki-67 after sorting with the FACS analysis (the third FACS analysis), after 74 days of incubation with the bacteria. 


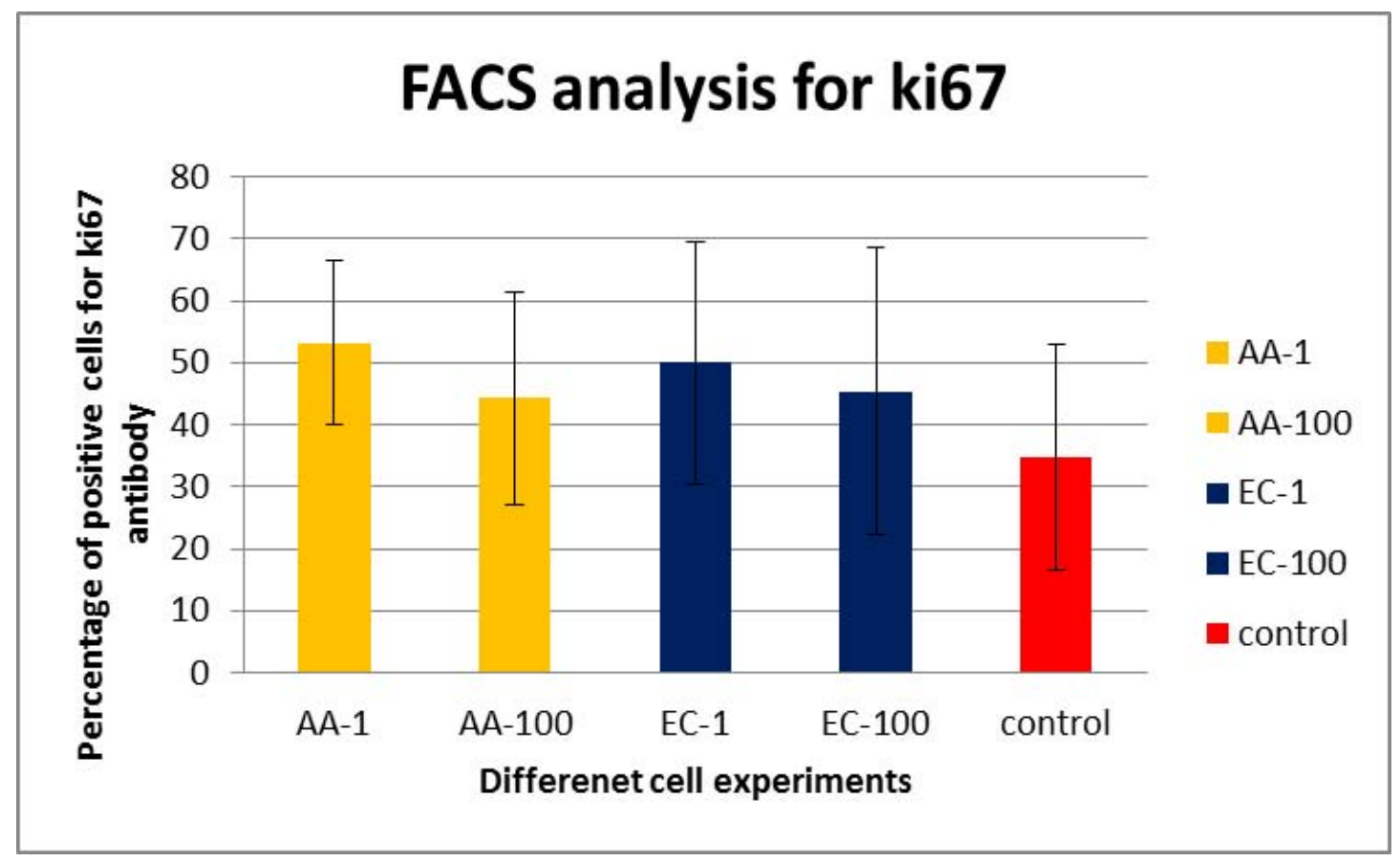

Figure 8: The averages and the standard deviations of the three successive FACS analyses of the MSCs for the ki-67 antibody, after 74 days of incubation with bacteria with different ratios. 

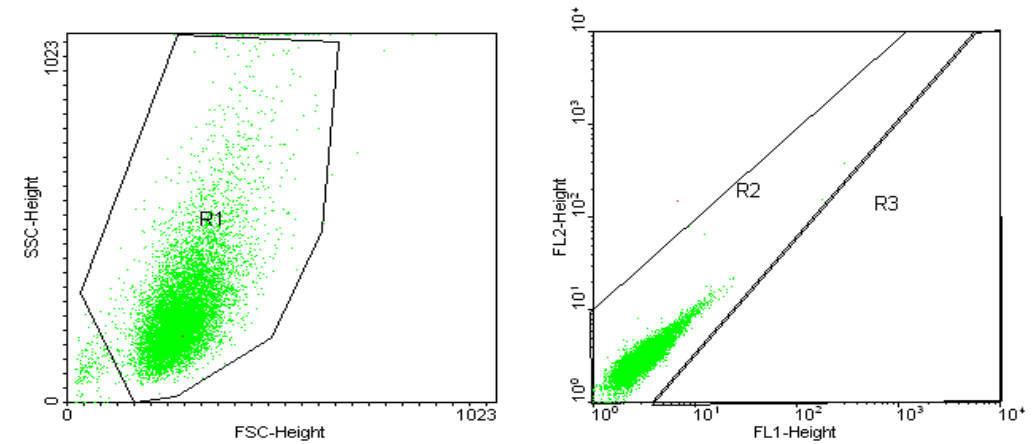

Figure 9a
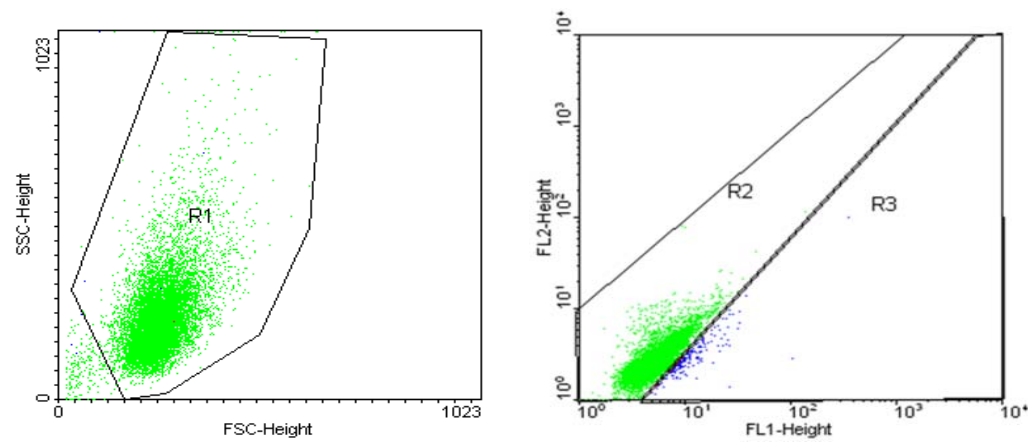

Figure 9b
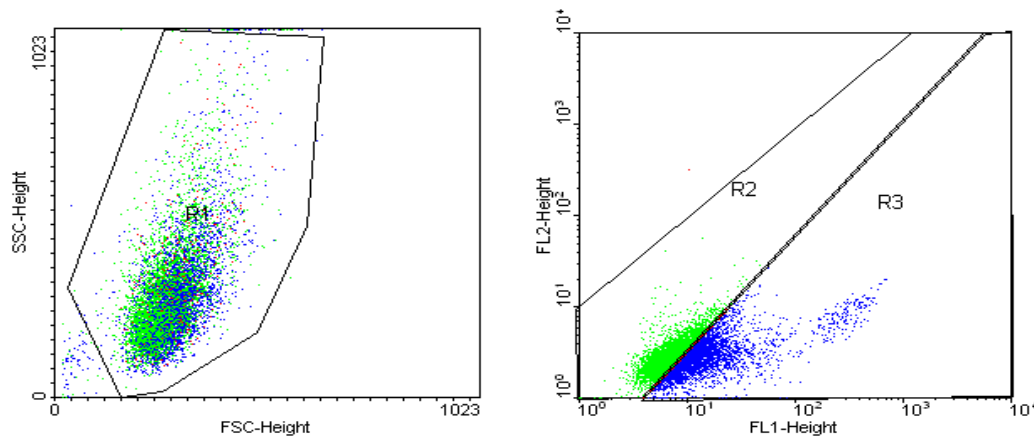

Figure 9c

Figure 9: The FACS analysis of the AA1 cells for the ki-67 after 60 days of incubation with the bacteria. Figure 9a: The negative control experiment, where the R1 region represents the dot plot of the whole MSCs population resulting from light scattering (side scatter versus forward scatter), R2 region represents the dot plot of the ki-67 unlabeled (negative) stem cell population gated from the R3 region, which represents the positive stem cell population 
labeled with ki-67 antibody (FITC). Figure 9b: The isocontrol experiment (only $2^{\text {ry }}$ anti-mouse antibody). Figure 9c: The cell sorting of the AA1 cells for the ki67 antibody, where the green dot plot represents the negative unlabeled cell population (R2), and the blue dot plot represents the positive stem cell population labeled with ki-67 antibody (FITC)(R3).

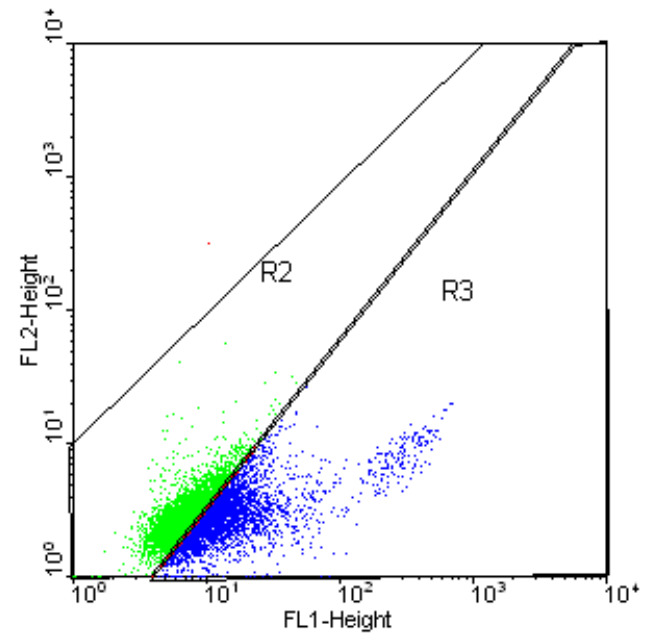

Figure 10a

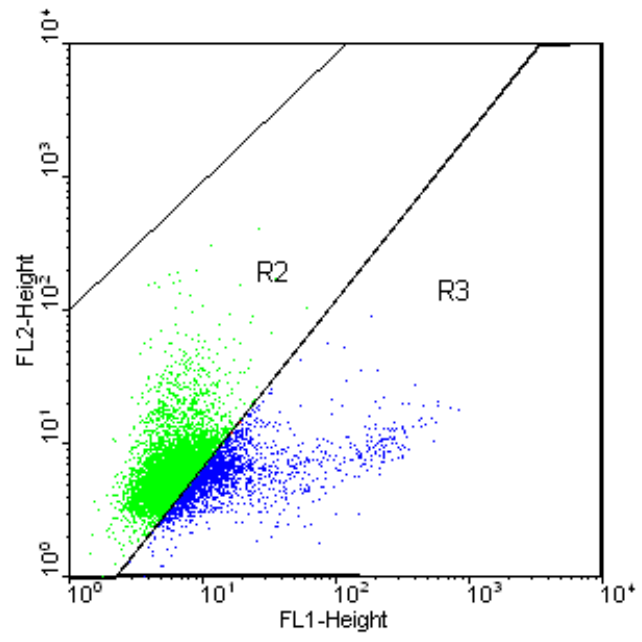

Figure 10b

Figure 10a: The cell sorting of the EC1 cells for the ki-67 antibody after 60 days of incubation with the bacteria, where the green dot plot represents the negative unlabeled cell population (R2), and the blue dot plot represents the positive stem cell population labeled with ki-67 antibody (FITC)(R3). Figure10b: The cell sorting of the EC100 cells for the ki-67 antibody, where the green dot plot represents the negative unlabeled cell population (R2), and the blue dot plot represents the positive stem cell population labeled with ki-67 antibody (FITC)(R3). 


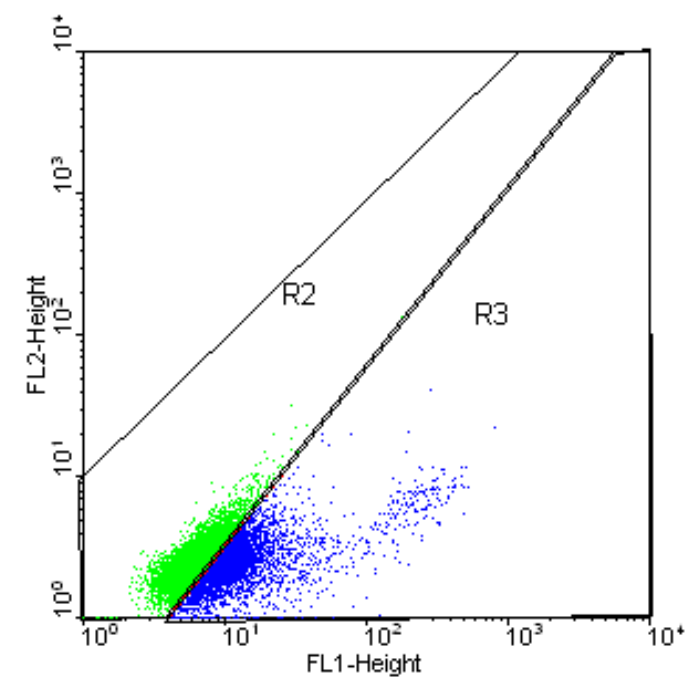

Figure 11a

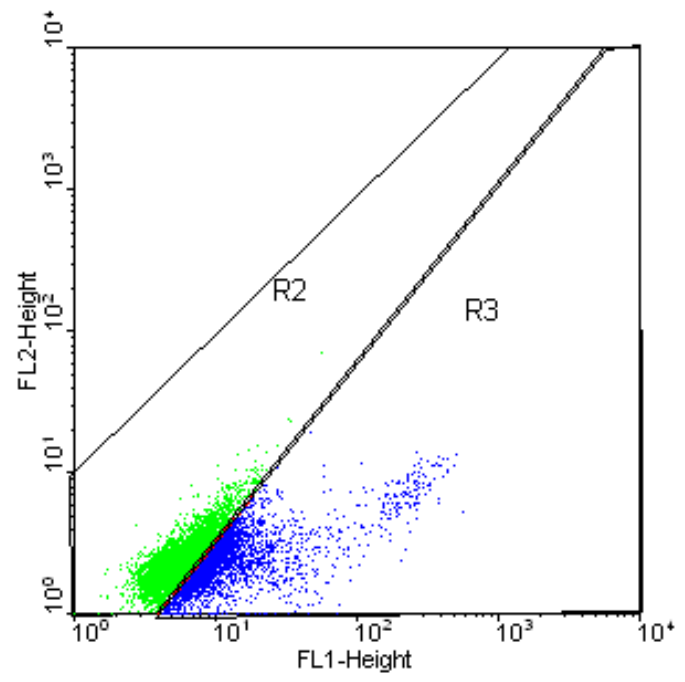

Figure 11b

Figure 11a: The cell sorting of the AA100 cells for the ki-67 antibody after 60 days of incubation with the bacteria, where the green dot plot represents the negative unlabeled cell population (R2), and the blue dot plot represents the positive stem cell population labeled with ki-67 antibody (FITC)(R3). Figure11b: The cell sorting of the control experiment cells for the ki-67 antibody, where the green dot plot represents the negative unlabeled cell population (R2), and the blue dot plot represents the positive stem cell population labeled with ki-67 antibody (FITC)(R3). 


\subsection{Testing the cells for stem cell markers after incubation with bacteria}

\subsubsection{Testing the cells for the stem cell markers (CD44, CD29, CD166, and CD105) with the immunohistochemistry after three weeks of incubation with bacteria}

After 3 weeks of incubation with the Actinobacillus actinomycetemcomitans and the Eikenella corrodens, the MSCs were tested for the stem cell markers which have been used for their identification as stem cells by Böcker et al. in 2008. The cells in the five different experiments (AA1, AA100, EC1, EC100, and the control) were checked for the CD44, CD29, CD166, and CD105 markers with the immunocytochemistry. All the MSCs showed positive reactions for the four stem cell markers indicating that the cells still preserved their stemness after 3 weeks of incubation with bacteria (Figures 12, 13, 14, 15,16 , and 17). 


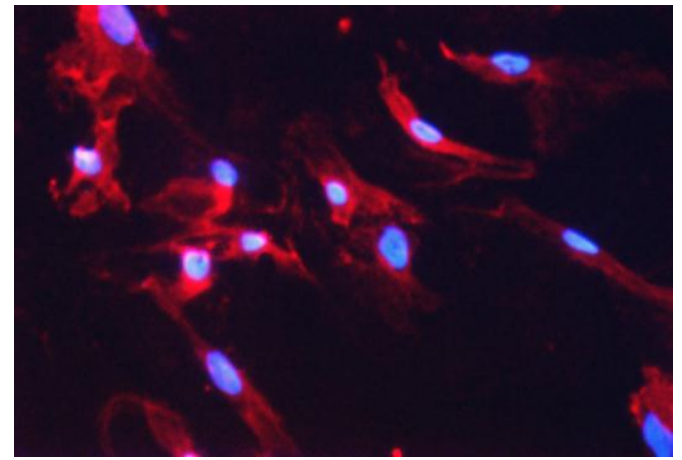

Figure 12

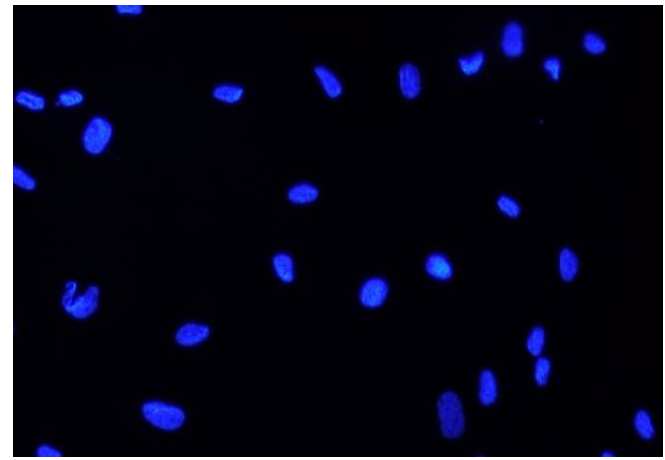

Figure 13

Figure 12: Staining of the AA1 cells with immunohistochemistry indicating a positive reaction for the CD44 antibody (PE) after 3 weeks of incubation with bacteria. Figure 13: Showing the negative control of the AA1 cells for the CD44 antibody.

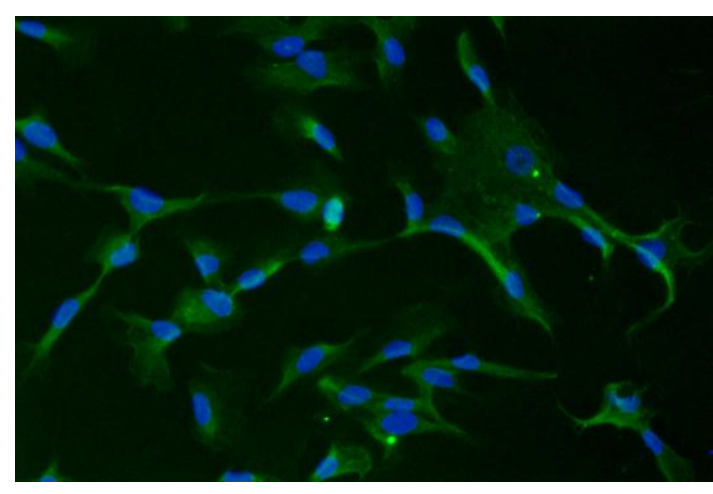

Figure 14

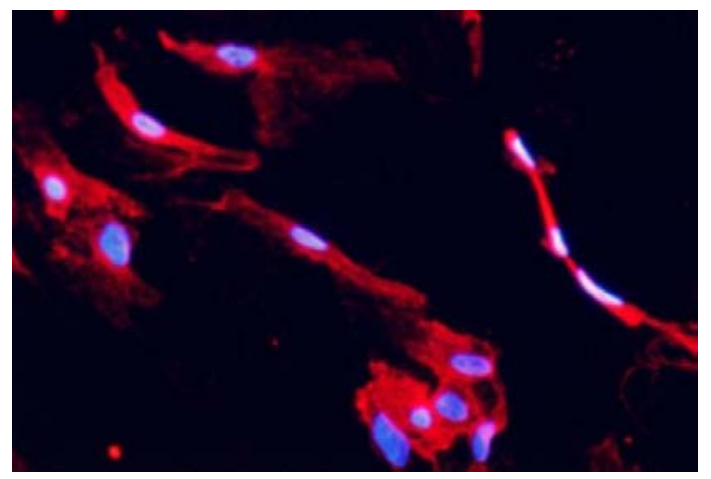

Figure 15

Figure 14: Staining of the AA100 cells with immunohistochemistry indicating a positive reaction for the CD166 antibody (FITC) after 3 weeks of incubation with bacteria. Figure 15: Staining of the EC1 cells with immunohistochemistry indicating a positive reaction for the CD29 antibody (PE) after 3 weeks of incubation with bacteria. 


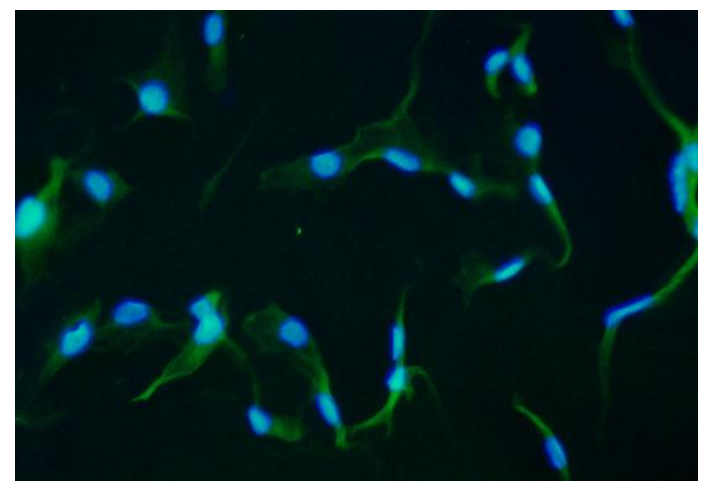

Figure 16

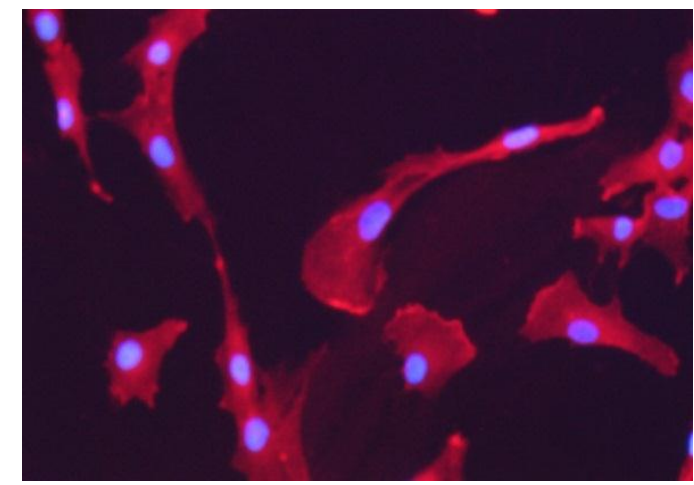

Figure 17

Figure 16: Staining of the EC100 cells with immunohistochemistry, indicating a positive reaction for the CD105 antibody (FITC) after 3 weeks of incubation with bacteria. Figure 17: Staining of the control cells with immunohistochemistry indicating a positive reaction for the CD44 antibody (PE) after 3 weeks of incubation with bacteria. 


\subsubsection{Testing the MSCs for the stemness markers (Klf4 and C-myc) genes and their associated effects on the osteogenic genes (Runx2 and Col1) using the real time PCR after 2 months of incubation with bacteria}

After two months of incubation with the bacteria, the stemness markers have been tested with the real time PCR.

\subsubsection{Isolation of the RNA from the cells}

The amounts of the RNA that have been isolated from the five different cell experiments were measured with the NanoDrop apparatus, and the following results were obtained (Table 5, Figure 18).

\begin{tabular}{|l|l|}
\hline Cell experiment & $\begin{array}{l}\text { Amount of the RNA } \\
\text { isolated in } \mathrm{ng} / \mu \mathrm{l}\end{array}$ \\
\hline AA1 & $635.7 \mathrm{ng} / \mu \mathrm{l}$ \\
\hline AA100 & $275.5 \mathrm{ng} / \mu \mathrm{l}$ \\
\hline EC1 & $195.3 \mathrm{ng} / \mu \mathrm{l}$ \\
\hline EC100 & $381.4 \mathrm{ng} / \mu \mathrm{l}$ \\
\hline Control & $358.9 \mathrm{ng} / \mu \mathrm{l}$ \\
\hline
\end{tabular}

Table 5: The measurements of the amounts of RNA that have been isolated from the five different cell experiments after 2 months of incubation with 
bacteria. The RNA measurements have been calculated with the NanoDrop apparatus.

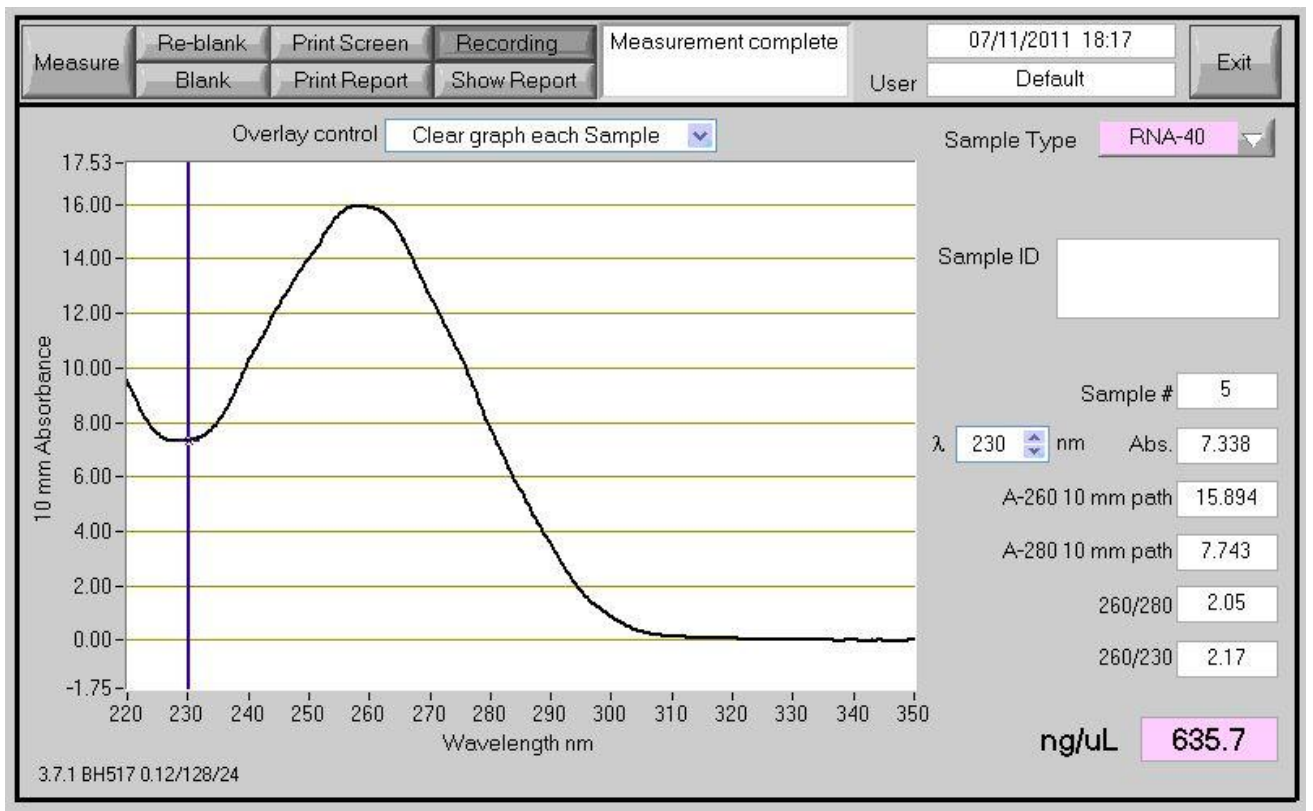

Figure 18: The NanoDrop apparatus measurement of the amount of the RNA isolated from the AA1 cells, after 2 months of incubation with Actinobacillus actinomycetemcomitans bacteria with 1:1 ratio.

\subsubsection{Efficiency of the primers}

Efficiency of the primers $(E)$ have been determined applying different dilution factors $(1: 1,1: 5,1: 10$, and 1:15) of the target CDNA. Real time PCR was then performed for the different dilutions, and the efficiency of the primers were calculated according to the equation $E=10^{(-1 / \text { slope })}$ (Pfaffl 2001) (Figure 19). 


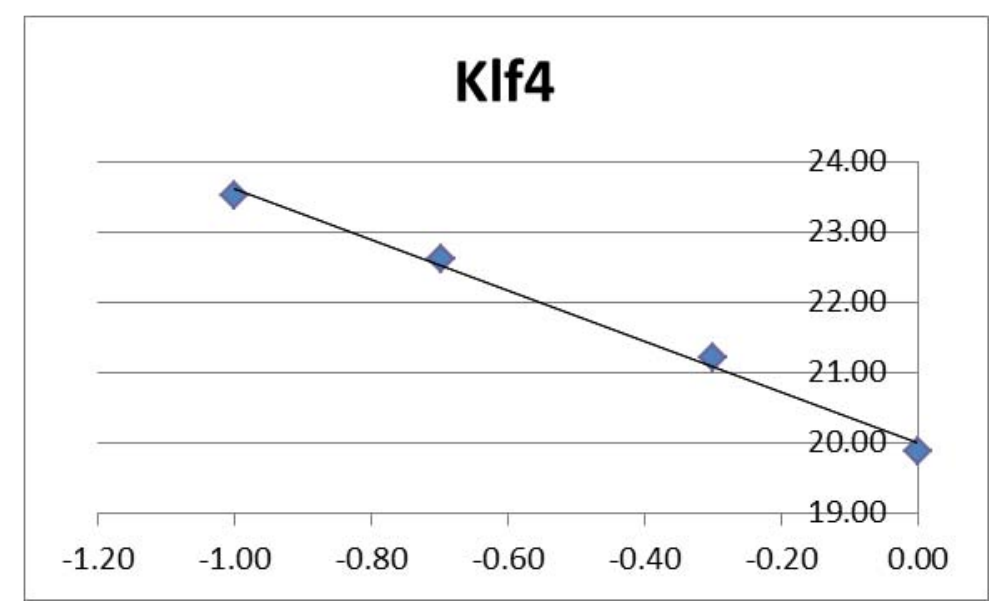

Figure 19: Efficiency curve of the Klf4 primer with the different dilution factors of the cDNA obtained from the AA1 cells after 2 months of incubation with bacteria, whereas the $x$-axis values are the logarithms of the different dilutions of the cDNA and the $y$-axis values are the averages of the Ct values.

\subsubsection{Determination of the relative expression of the stemness markers (Klf4 and C-myc) genes and their associated effects on the osteogenic genes (Runx2 and Col1) after bacterial induction}

To determine whether a gene is up or down regulated, the equation in Figure 20 was used according to the Pfaffl model (Pfaffl 2001). The Pfaffl model is a mathematical model that was presented to determine the relative quantification of a target gene in comparison to a reference (housekeeping) gene. The relative expression ratio of the target is first calculated based on the efficiency and the Ct deviation $(\Delta \mathrm{Ct}$ ) values of the treated sample (cells incubated with bacteria) versus a control sample (the control cells), then 
expressed in comparison to a reference gene $(\beta 2 M)$. The $\beta 2 M$, which is one of the housekeeping genes, has been found and proved to be unregulated under the different experimental conditions applied in this study (long periods of incubation with bacteria), and therefore, the $\beta 2 \mathrm{M}$ has been used as a reference gene to which the inspected genes (C-myc, Runx2, Klf4, and Col1) have been normalized in order to determine their relative expression ratios according to the Pfaffl equation.

\section{ratio $=\underline{\left(E_{\text {target }}\right)^{\Delta C t \text { target (control-treated) }}}$ \\ $\left(E_{\text {ref }}\right)^{\Delta C t \text { ref (control-treated) }}$}

Figure 20: Pfaffl equation, where the $E_{\text {target }}$ is the efficiency of the target gene, $E_{\text {ref }}$ is the efficiency of the reference gene $(\beta 2 \mathrm{M}), \Delta \mathrm{Ct}$ target is the $\mathrm{Ct}$ deviation of control - treated sample of the target gene, and $\Delta \mathrm{Ct}$ ref is the $\mathrm{Ct}$ deviation of control - treated sample of the reference gene $(\beta 2 \mathrm{M})$. According to this equation, the relative expression ratios of the different genes have been calculated.

According to the Pfaffl model, and the Pfaffl relative expression software tool (REST), the values that will be obtained from the equation will be either positive or negative. So if the value that will be obtained from the equation is +2 , this means that the target gene is over expressed by 2 folds in the treated sample, when being compared to its original expression in the control sample, and if the value that will be obtained from the equation is -1 , this means that the target gene is under expressed by 1 fold in the treated sample, when being compared to its original expression in the control sample (Pfaffl 2001, Pfaffl et al. 2002).

The results that were obtained with the C-myc and the Klf4 by the real time PCR were highly significant. All of the 4 different cell experiments (incubated with bacteria) showed up-regulation for the C-myc and the KIf4 genes after 
the 2 months of bacterial incubation (Figures 21 and 22). It was also noticed that the EC100 cells always exhibited the highest relative expression ratios for both C-myc and Klf4 genes when compared to the cells in the other experiments. The effects of the bacterial incubation on the osteogenic markers (Runx2 and Col1 genes) were also determined by the real time PCR. The previous results that were obtained with the Klf4 and the C-myc genes were found to be matching with those obtained with the Runx2 and the Col1 genes, whereas all the different cell experiments showed up-regulation for both Runx2 and Col1 genes (Figures 23 and 24), and significantly, and as in the case of Klf4 and C-myc, the EC100 cells always exhibited the highest relative expression ratios when compared with the cells in the other experiments. There is no certain explanation for the always high relative expression ratios in the case of EC100 cells, but it may be relevant to the number of the bacterial colonies, and the degree of bacterial virulence. The up-regulation of the genes responsible for stemness, and its significant effect on the up-regulation of the osteogenic genes in response to incubation with periodontal pathogens, supports the idea of the usage of the BMSCs as a preferable stem cell source for achieving complete stem cell based regeneration of the alveolar bone resorption that is associated with the periodontal disease. 


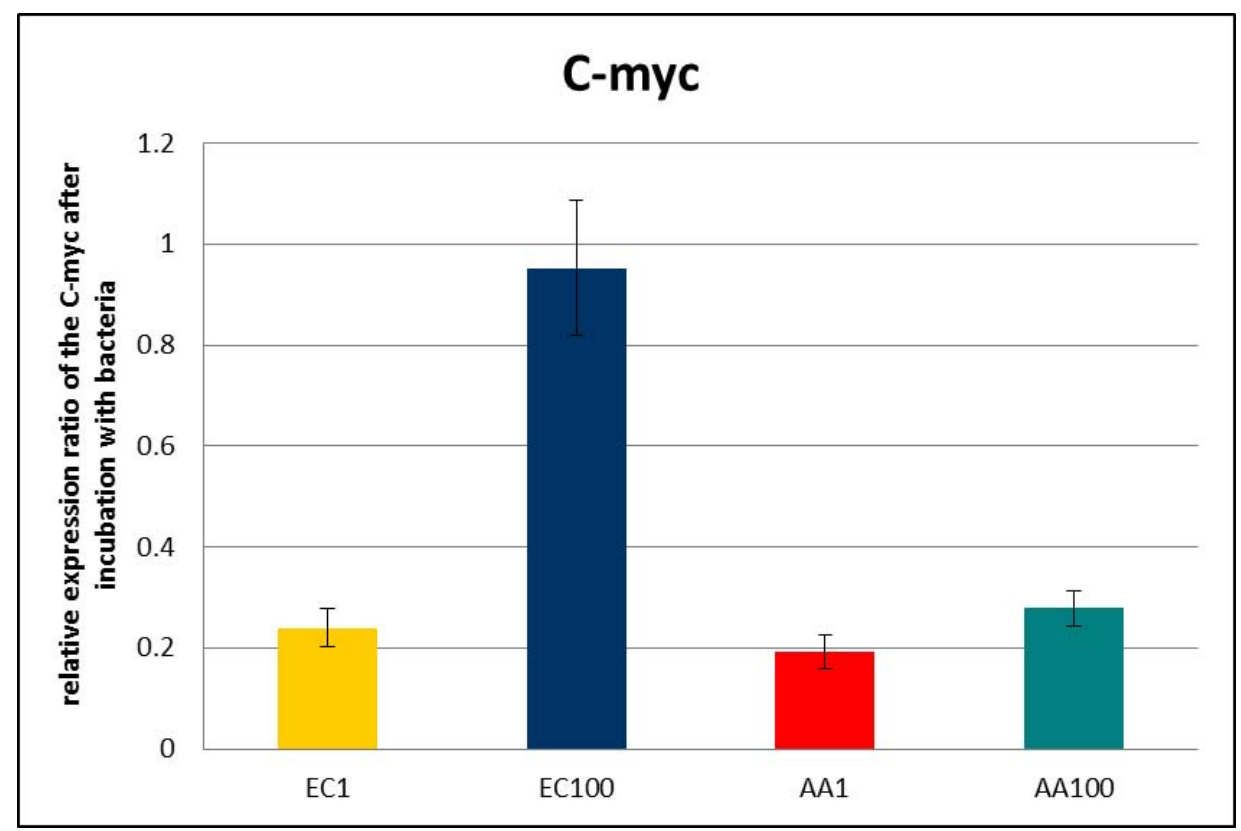

Figure 21: The relative expression ratios of the C-myc gene in the 4 different cell experiments after 2 months period of incubation with bacteria. The C-myc relative expression ratios were normalized to the expression levels of the $\beta 2 \mathrm{M}$.

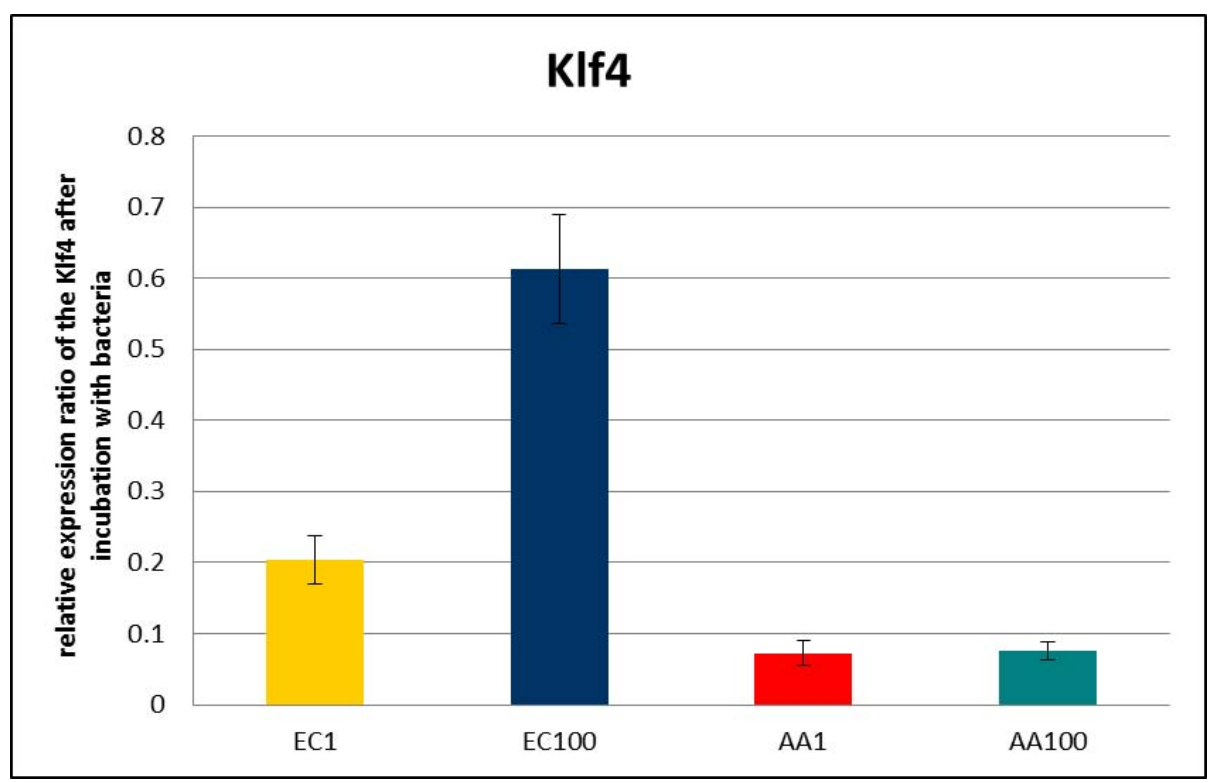

Figure 22: The relative expression ratios of the Klf4 gene in the 4 different cell experiments after 2 months period of incubation with bacteria. The Klf4 relative expression ratios were normalized to the expression levels of the $\beta 2 \mathrm{M}$. 


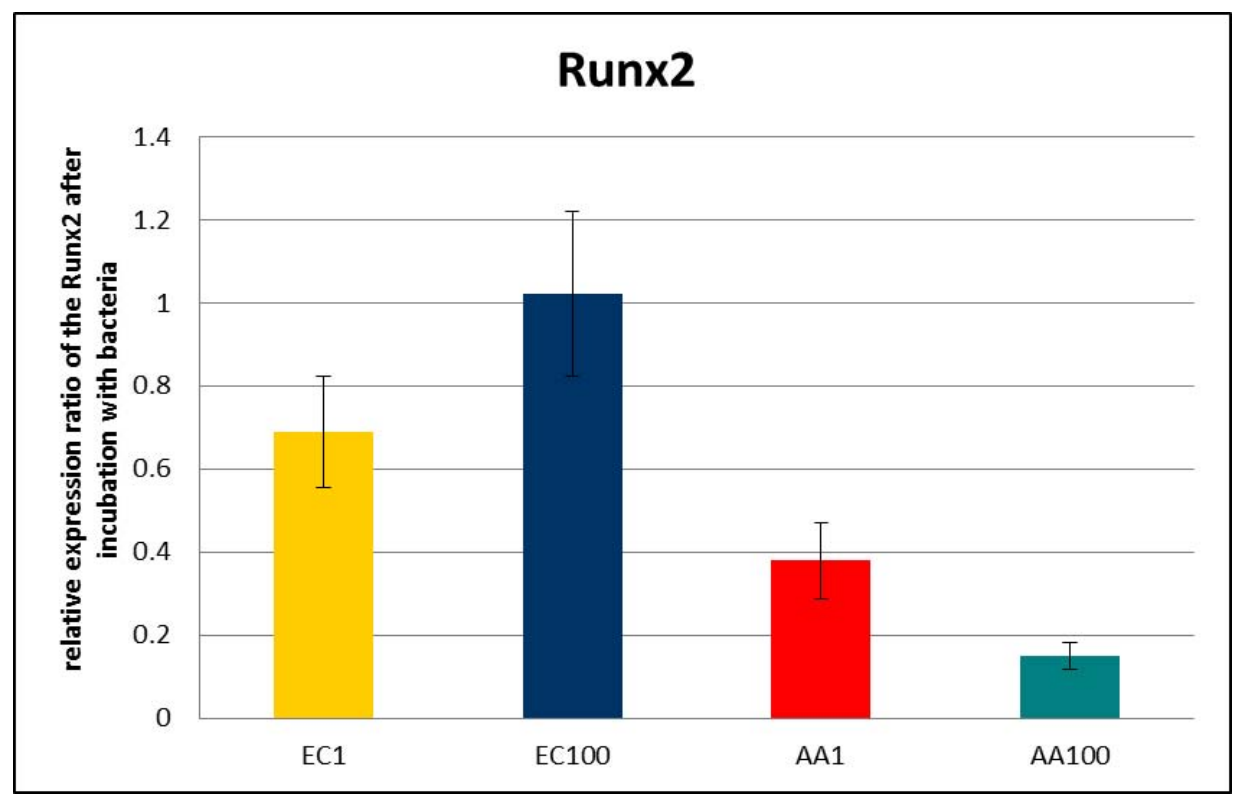

Figure 23: The relative expression ratios of the Runx2 gene in the 4 different cell experiments after 2 months period of incubation with bacteria. The Runx2 relative expression ratios were normalized to the expression levels of the $\beta 2 \mathrm{M}$.

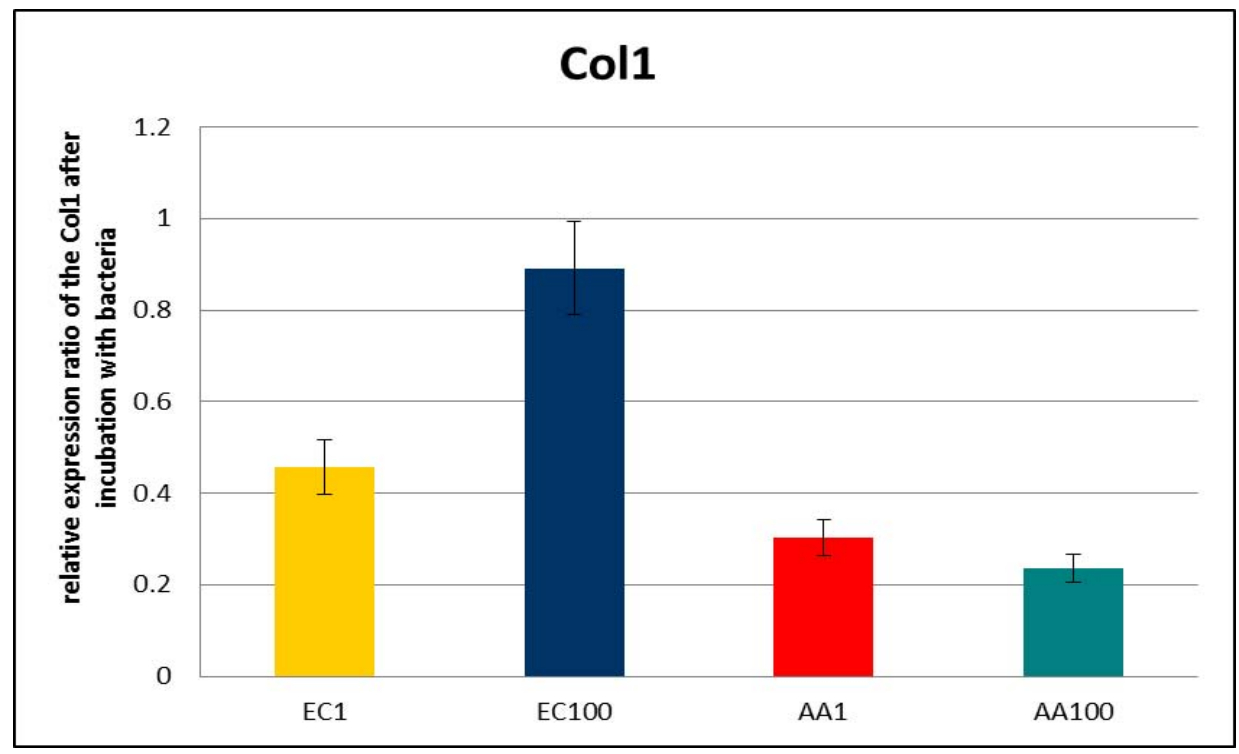

Figure 24: The relative expression ratios of the Col1 gene in the 4 different cell experiments after 2 months period of incubation with bacteria. The Col1 relative expression ratios were normalized to the expression levels of the $\beta 2 \mathrm{M}$. 


\subsection{Testing the MSCs for the osteogenic differentiation after the incubation with the osteogenic differentiation medium}

After 2 months of incubation of the cells with bacteria, the cells were then transferred to the osteogenic differentiation medium. Cells were divided into 2 main groups:

1. Cells which were osteodifferentiated with mesenchymal stem cell osteogenic differentiation medium (Promocell $\mathrm{GmbH}$, Heidelberg, Germany). The cells in this group were given the names (O-AA1-, OAA100-, O-EC1-, O-EC100-, and O-control).

2. Cells which were osteodifferentiated with mesenchymal stem cell osteogenic differentiation medium and with the addition of the bacteria to the osteogenic differentiation medium with the same previous ratios of incubation (1:1 and 1:100). The cells in this group were given the names $(\mathrm{O}-\mathrm{AA} 1+, \mathrm{O}-\mathrm{AA100+,} \mathrm{O}-\mathrm{EC1}+$, and O-EC100+).

- $(\mathrm{O}-\mathrm{AA} 1+)$ with 1 bacterial colony $(\mathrm{AA}): 1$ cell.

- (O-AA100+) with 1 bacterial colony (AA):100 cells.

- $(\mathrm{O}-\mathrm{EC} 1+)$ with 1 bacterial colony $(\mathrm{EC}): 1$ cell.

- (O-EC100+) with 1 bacterial colony (EC):100 cells. 
3. Thus finally 9 different cell experiments were obtained:

- 1. O-AA1+

2. O-AA100+

3. O-EC1+

4. O-EC100+

- 5. O-AA1-

6. O-AA100-

7. O-EC1-

8. O-EC100-

9. O-control osteogenic differentiation medium

with bacteria (+).

\subsubsection{Alkaline phosphatase staining}

After 8 days of the incubation of the MSCs within the osteogenic differentiation medium, cells were checked for the alkaline phosphatase enzyme activity. In all of the 9 different cell experiments positive reactions for the alkaline phosphatase were obtained for approximately $90 \%$ of the investigated cells (Figures 25, 26, 27, 28, 29, 30, 31, 32, 33, and 34).

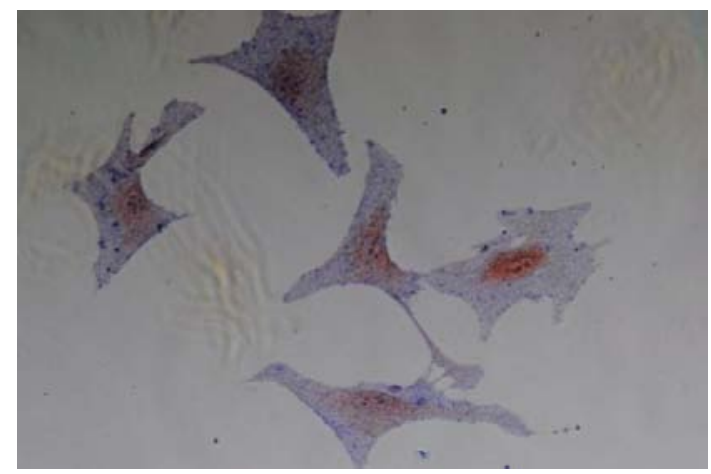

Figure 25

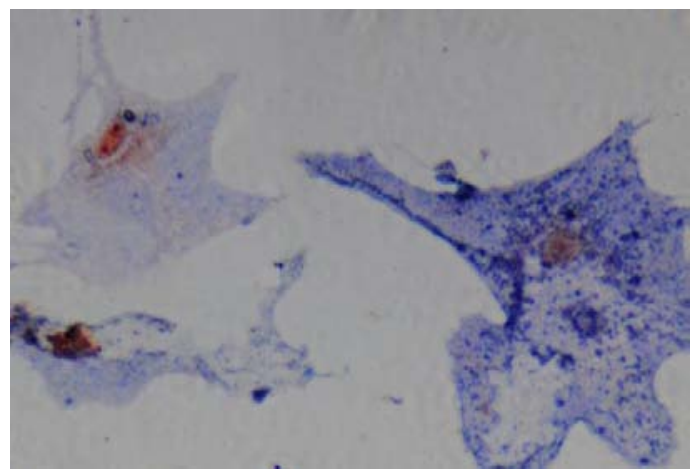

Figure 26

Figure 25: Alkaline phosphatase staining for the (O-EC1-) cells after 8 days of incubation with the osteogenic differentiation medium without bacterial 
addition. Figure 26: Alkaline phosphatase staining for the (O-AA1-) cells after 8 days of incubation with the osteogenic differentiation medium without bacterial addition.

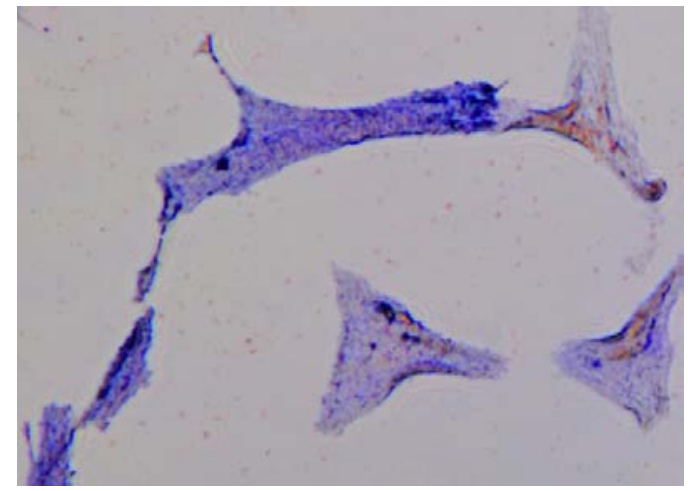

Figure 27

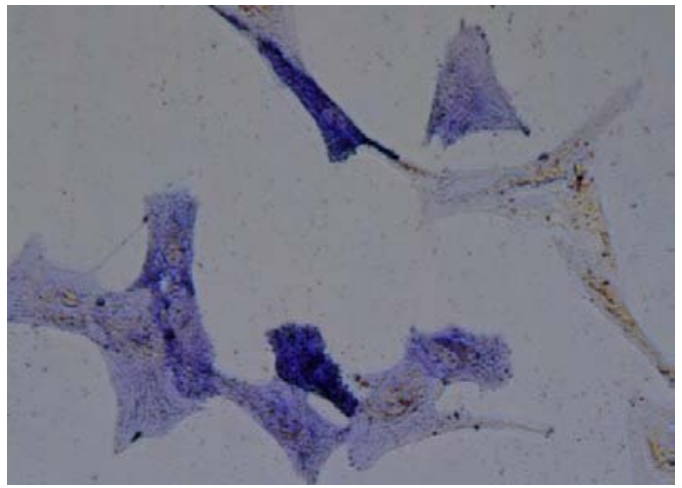

Figure 28

Figure 27: Alkaline phosphatase staining for the $(\mathrm{O}-\mathrm{EC} 1+)$ cells after 8 days of incubation with the osteogenic differentiation medium with the addition of Eikenella corrodens (1:1 ratio). Figure 28: Alkaline phosphatase staining for the $(\mathrm{O}-\mathrm{AA} 1+)$ cells after 8 days of incubation with the osteogenic differentiation medium with the addition of Actinobacillus actinomycetemcomitans (1:1 ratio).

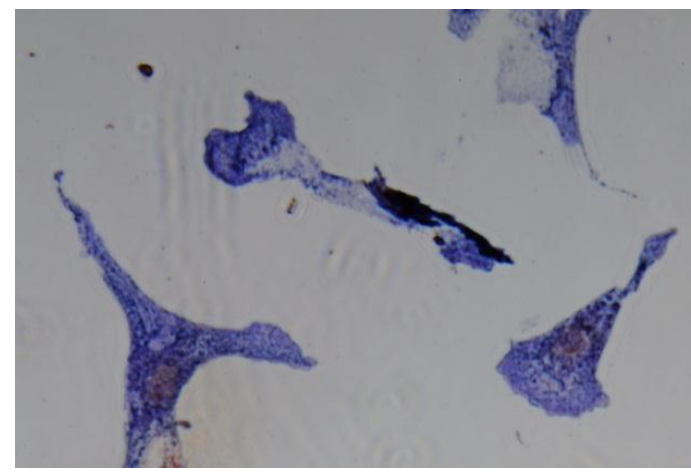

Figure 29

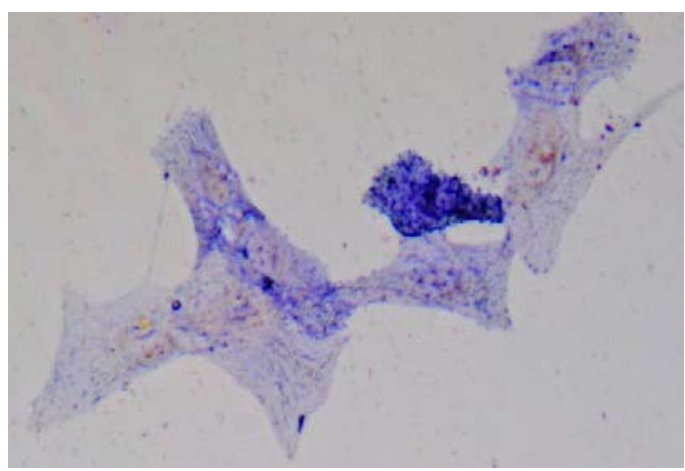

Figure 30

Figure 29: Alkaline phosphatase staining for the (O-EC100-) cells after 8 days of incubation with the osteogenic differentiation medium without bacterial addition. Figure 30: Alkaline phosphatase staining for the (O-AA100-) cells 
after 8 days of incubation with the osteogenic differentiation medium without bacterial addition.

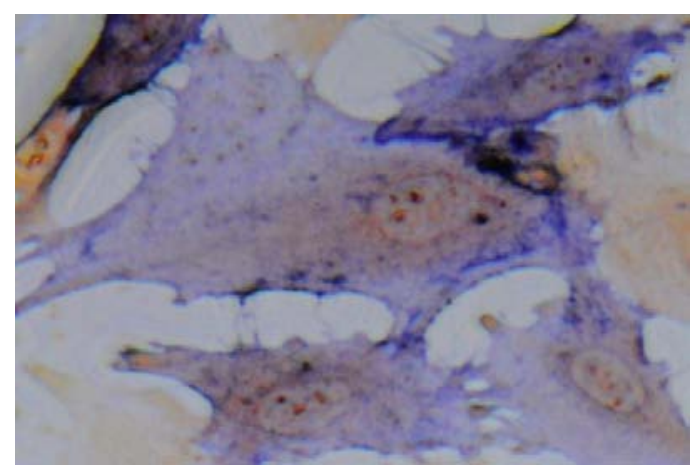

Figure 31

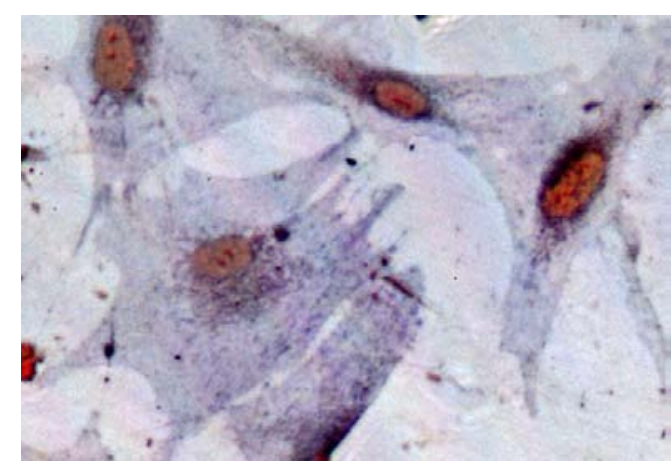

Figure 32

Figure 31: Alkaline phosphatase staining for the (O-EC100+) cells after 8 days of incubation with the osteogenic differentiation medium with the addition of Eikenella corrodens (1:100 ratio). Figure 32: Alkaline phosphatase staining for the (O-AA100+) cells after 8 days of incubation with the osteogenic differentiation medium with the addition of Actinobacillus actinomycetemcomitans (1:100 ratio) to the medium. 


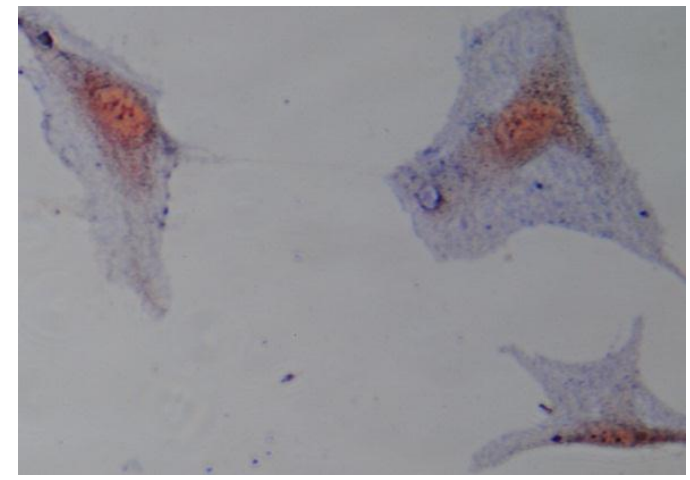

Figure 33

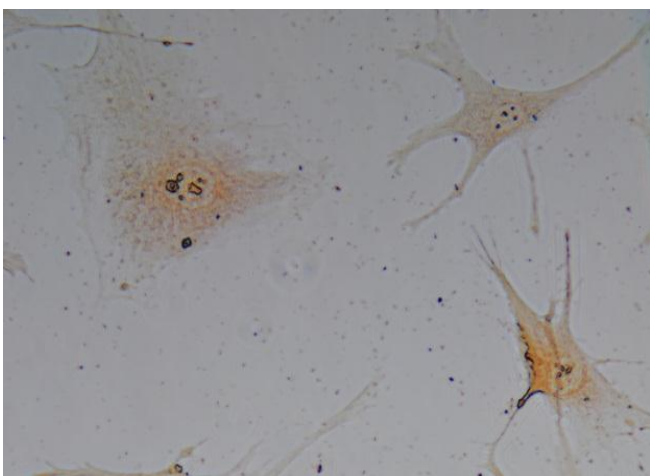

Figure 34

Figure 33: Alkaline phosphatase staining for cells of the O-control experiment (no previous 2 months of bacterial incubation) after 8 days of incubation with the osteogenic differentiation medium without bacterial addition to the medium. Figure 34: The negative control.

\subsubsection{Testing the MSCs for the osteogenic differentiation with the help of immunocytochemistry}

After 12 days of incubation with the osteogenic differentiation medium, the cells in the 9 different experiments were checked for osteopontin with the help of immunocytochemistry. Osteopontin is an extracellular structural protein, and an important component of the bone. It also acts as an indicator of bone turnover.

The MSCs in all of the 9 different experiments (O-AA1+, O-AA1-, O-AA100+, O-AA100-, O-EC1+, O-EC1-, O-EC100+, O-EC100-, and O-control) showed positive reactions with the osteopontin antibodies (Figures 35, 36, 37, 38, 39, 40, 41, 42, 43, and 44). 


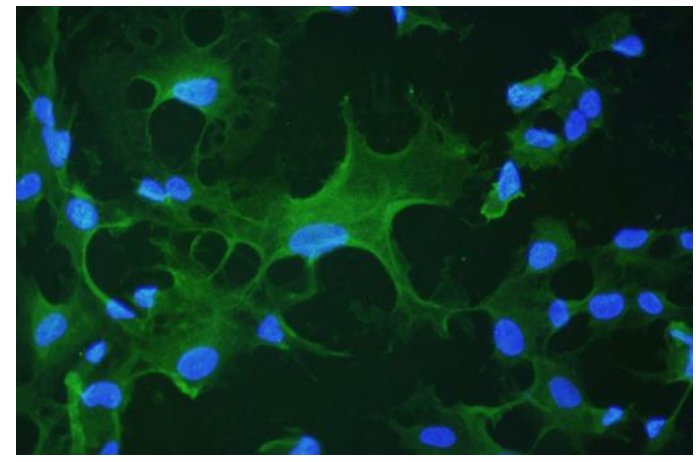

Figure 35

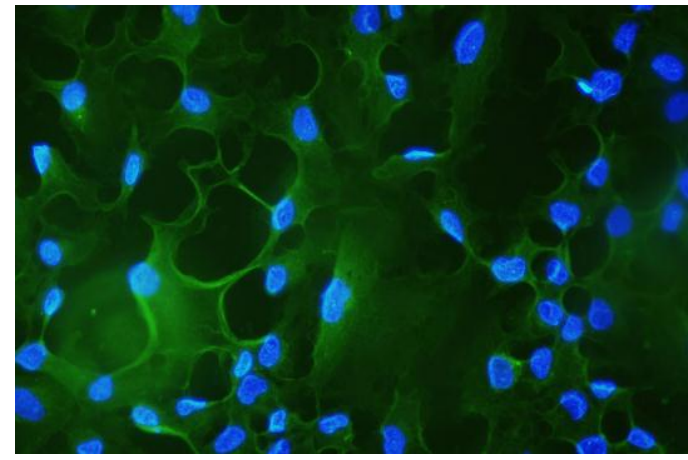

Figure 36

Figure 35: Staining of the (O-EC1-) cells with immunohistochemistry, indicating a positive reaction for the osteopontin antibody (FITC), after 12 days of incubation in the osteogenic differentiation medium without bacterial addition to the medium. Figure 36: Staining of the (O-AA1-) cells with immunohistochemistry, indicating a positive reaction for the osteopontin antibody (FITC), after 12 days of incubation in the osteogenic differentiation medium without bacterial addition to the medium.

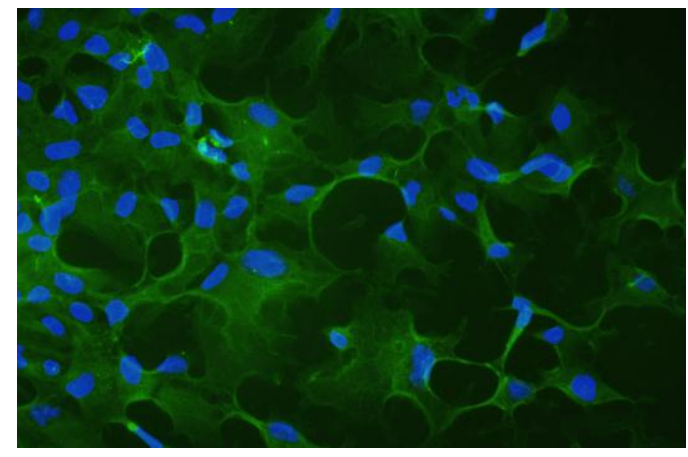

Figure 37

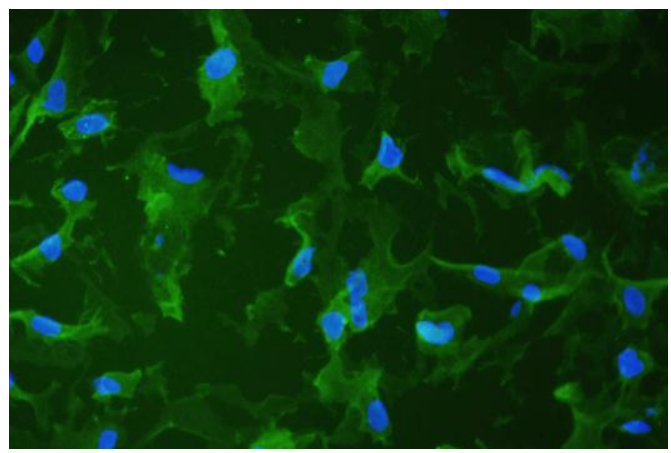

Figure 38

Figure 37: Staining of the (O-EC1+) cells with immuno-histochemistry, indicating a positive reaction for the osteopontin antibody (FITC), after 12 days of incubation in the osteogenic differentiation medium of incubation with the osteogenic differentiation medium with the addition of Eikenella corrodens (1:1 ratio) to the medium. Figure 38: Staining of the (O-AA1+) cells with immunohistochemistry, indicating a positive reaction for the osteopontin 
antibody (FITC), after 12 days of incubation in the osteogenic differentiation medium of incubation with the addition of Actinobacillus actinomycetemcomitans (1:1 ratio) to the medium.

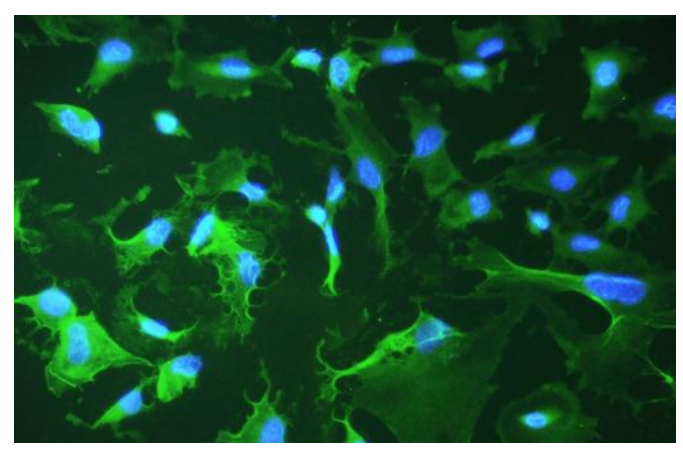

Figure 39

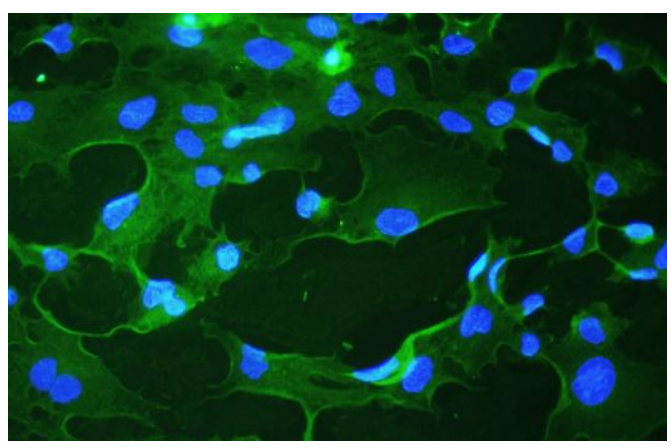

Figure 40

Figure 39: Staining of the (O-EC100-) cells with immunohistochemistry, indicating a positive reaction for the osteopontin antibody (FITC), after 12 days of incubation in the osteogenic differentiation medium without bacterial addition to the medium. Figure 40: Staining of the (O-AA100-) cells with immunohistochemistry, indicating a positive reaction for the osteopontin antibody (FITC), after 12 days of incubation in the osteogenic differentiation medium without bacterial addition to the medium. 


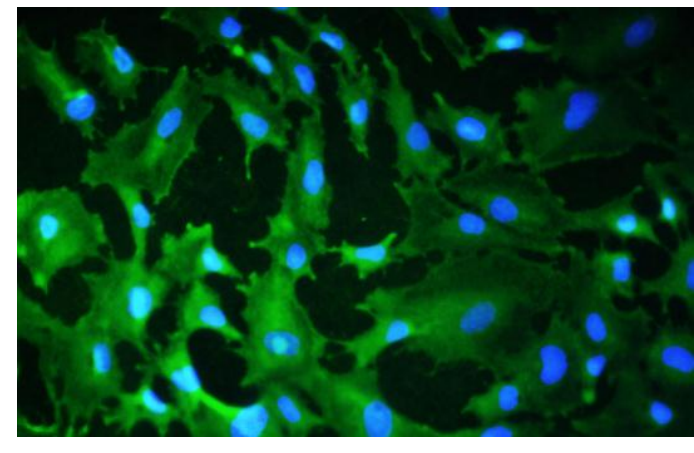

Figure 41

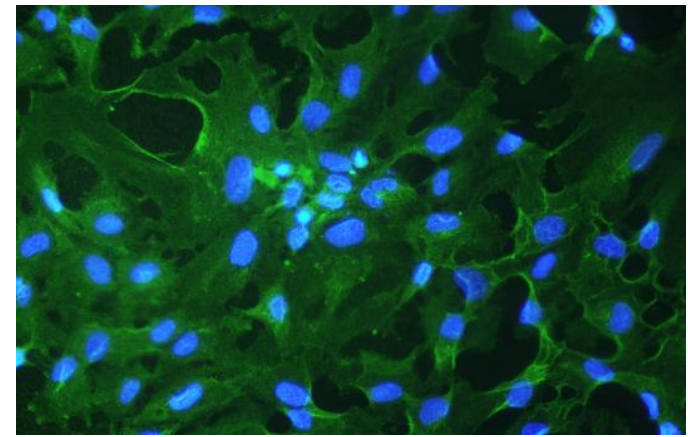

Figure 42

Figure 41: Staining of the (O-EC100+) cells with immunohistochemistry, indicating a positive reaction for the osteopontin antibody (FITC), after 12 days of incubation in the osteogenic differentiation medium of incubation with the osteogenic differentiation medium with the addition of Eikenella corrodens (1:100 ratio) to the medium. Figure 42: Staining of the (O-AA100+) cells with immunohistochemistry, indicating a positive reaction for the osteopontin antibody (FITC), after 12 days of incubation in the osteogenic differentiation medium of incubation with the addition of Actinobacillus actinomycetemcomitans (1:100 ratio) to the medium.

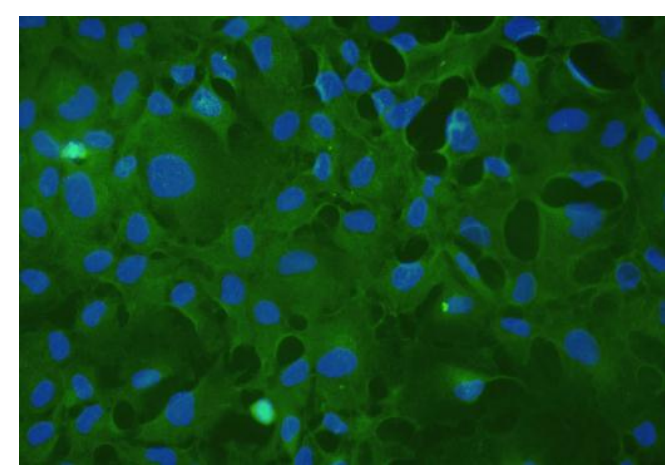

Figure 43

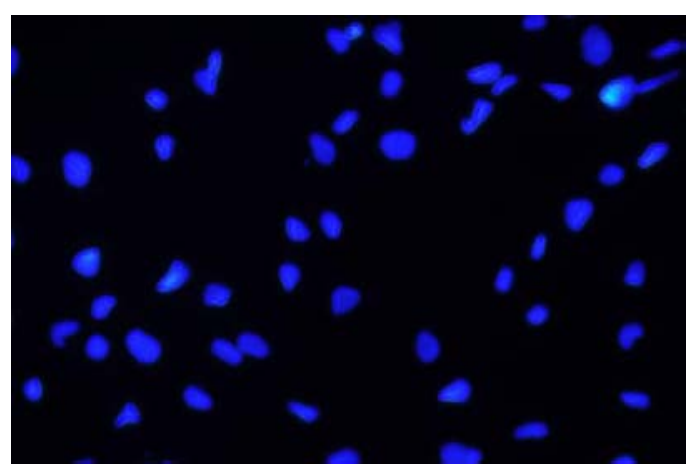

Figure 44

Figure 43: Staining of the cells of the O-control experiment (no previous 2 months of bacterial incubation) with immunohistochemistry, indicating a positive reaction for the osteopontin antibody (FITC), after 12 days of incubation in the osteogenic differentiation medium of incubation without 
bacterial addition to the medium. Figure 44: Showing the negative control of the $(\mathrm{O}-\mathrm{AA} 1+)$ cells for the osteopontin antibody.

\subsubsection{Testing the MSCs for the degree of osteogenic differentiation using the real time PCR (testing the expression of the Runx2 and Col1 after osteogenic differentiation)}

After a period of 2 weeks of incubation with the osteogenic differentiation medium, MSCs in the 9 different cell experiments (O-AA1+, O-AA1-, OAA100+, O-AA100-, O-EC1+, O-EC1-, O-EC100+, O-EC100-, and O-control) were tested for the degrees of osteogenic differentiation using the real time PCR. The relative expression ratios of the Runx2 and the Col1 genes were calculated according to the Pfaffl model, and the exact degrees of the up or the down regulations of the genes were obtained (Figures 45 and 46, Tables 6 and 7$)$.

According to the Pfaffl relative expression software tool, the relative expression ratios were calculated based on the efficiency and the Ct deviation $(\Delta \mathrm{Ct})$ values of the treated samples (cells incubated with osteogenic differentiation medium; O-AA1+, O-AA1-, O-AA100+, O-AA100-, O-EC1+, OEC1-, O-EC100+, O-EC100-, and O-control) versus the control samples which are the original cell experiments without the incubation with the osteogenic differentiation medium, and after the incubation with bacteria (AA1, AA100, EC1, EC100, and control cell experiments). According to this, each original cell experiment without the incubation with the osteogenic differentiation medium will be regarded as a control in the Pfaffl model for 2 cell experiments after the incubation with the osteogenic differentiation medium except for the 
original control cell experiment which will be regarded as a control only for the O-control cell experiment, this can be more clarified as following:

1. AA1 (which is the original $A A 1$ cell experiment after the incubation with bacteria and without the incubation with the osteogenic differentiation medium) will be used as a control in the Pfaffl equation for the $(\mathrm{O}$ $A A 1+$ ) cell experiment (which is the AA1 cell experiment after the incubation with osteogenic differentiation medium containing bacteria with the 1:1 ratio "+") and for the (O-AA1-) cell experiment (which is the AA1 cell experiment after the incubation with osteogenic differentiation medium that does not contain bacteria “-“").

2. AA100 (which is the original AA100 cell experiment after the incubation with bacteria and without the incubation with the osteogenic differentiation medium) will be used as a control in the Pfaffl equation for the $(\mathrm{O}-\mathrm{AA} 100+)$ cell experiment (which is the AA100 cell experiment after the incubation with osteogenic differentiation medium containing bacteria with the $1: 100$ ratio "+" ) and for the (O-AA100-) cell experiment (which is the AA1 cell experiment after the incubation with osteogenic differentiation medium that does not contain bacteria “-“").

3. EC1 (which is the original EC1 cell experiment after the incubation with bacteria and without the incubation with the osteogenic differentiation medium) will be used as a control in the Pfaffl equation for the $(\mathrm{O}$ EC1+) cell experiment (which is the EC1 cell experiment after the incubation with osteogenic differentiation medium containing bacteria with the 1:1 ratio "+") and for the (O-EC1-) cell experiment (which is the EC1 cell experiment after the incubation with osteogenic differentiation medium that does not contain bacteria "_“").

4. EC100 (which is the original EC100 cell experiment after the incubation with bacteria and without the incubation with the osteogenic differentiation medium) will be used as a control in the Pfaffl equation for the (O-EC100+) cell experiment (which is the EC100 cell experiment after the incubation with osteogenic differentiation medium 
containing bacteria with the 1:100 ratio "+") and for the (O-EC100-) cell experiment (which is the EC100 cell experiment after the incubation with osteogenic differentiation medium that does not contain bacteria "-" ).

5. The control cell experiment (which is the original control cell experiment in which the cells were not incubated with bacteria at all in the first experiment and without incubation with osteogenic differentiation medium in the second experiment) will be used as a control in the Pfaffl equation for the (O-control) cell experiment (the original control cell experiment that was not incubated with bacteria at all, and after the incubation with osteogenic differentiation medium that does not contain bacteria).

Therefore, and according to what was explained previously, the relative expression ratios were calculated based on the efficiency and the Ct deviation $(\triangle \mathrm{Ct})$ values of treated samples (cells incubated with osteogenic differentiation medium; O-AA1+, O-AA1-, O-AA100+, O-AA100-, O-EC1+, OEC1-, O-EC100+, O-EC100-, and O-control) versus control samples which are the AA1 cell experiment (as a control for O-AA1+, O-AA1-), the AA100 cell experiment (as a control for O-AA100+, O-AA100-), the EC1 cell experiment (as a control for O-EC1+, O-EC1-), the EC100 cell experiment (as a control for O-EC100+, O-EC100-), and the control cell experiment (as a control for Ocontrol), then they were expressed in comparison to a reference gene ( $\beta 2 \mathrm{M})$. The $\beta 2 \mathrm{M}$, which is one of the housekeeping genes, has been found and proved to be unregulated under the different experimental conditions applied in this case study (incubation with the osteogenic differentiation medium for 2 weeks), and therefore, the $\beta 2 \mathrm{M}$ has been used as a reference gene to which the inspected genes (Runx2, and Col1) have been normalized in order to determine their relative expression ratios after the incubation with the osteogenic differentiation medium according to the Pfaffl equation.

Interestingly, the MSCs in all the nine different cell experiments showed upregulation of the two genes (Runx2 and Col1) enforcing the results obtained 
by the immunohistochemistry and the alkaline phosphatase staining. Relations between the relative expression ratios of the MSCs in the different experiments were significant. For the cells incubated with the Actinobacillus actinomycetemcomitans, the $(\mathrm{O}-\mathrm{AA} 1+)$ cells always exhibited the lowest relative expression ratios, while the (O-AA100+) cells always exhibited the highest relative expression ratios ( +9.56 with Runx2 and +5.73 with Col1). The cells in all of the different Actinobacillus actinomycetemcomitans cell experiments (O-AA1-, O-AA100-, and O-AA100+) exhibited higher relative expression ratios than the cells in the (O-control) experiment except for the $(\mathrm{O}-\mathrm{AA} 1+)$ cells which exhibited lower relative expression ratio than the $(\mathrm{O}-$ control) cells. These results were found to be consistent with both of the Col1 and Runx2 genes. For the cells incubated with the Eikenella corrodens, the relations between the relative expression ratios were not the same with the Col1 and Runx2 genes. In the case of Runx2, only the (O-EC100+) cells showed relative expression ratio $(+2.81)$ higher than the O-control cells $(+1.907)$, while the rest of the cells in the different experiments showed relative expression ratios lower than those obtained from the (O-control) cells. Results with the Col1 were significantly different from those obtained with the Runx2, the (O-EC1-) cells showed an extremely high relative expression ratio $(+6.56)$ when compared with the (O-control) cells $(+1.32)$. The relative expression ratios obtained from the cells in the rest of the EC cell experiments (O-EC1+, O-EC100-, and O-EC100+) were lower than those obtained from the (O-control) cells. The (O-EC1+) cells always showed the lowest relative expression ratios with both of the Col1 and Runx2 genes. It may be possible that the addition of high numbers of bacteria (1:1 ratio) with the osteogenic differentiation medium, may have affected the chemical composition of the differentiation medium, resulting in the decrease of the osteogenic differentiation of the $(\mathrm{O}-\mathrm{AA} 1+)$ and $(\mathrm{O}-\mathrm{EC} 1+)$ cells. 
Table 6:

\begin{tabular}{|l|l|l|}
\hline $\begin{array}{l}\text { Cell } \\
\text { experiment }\end{array}$ & $\begin{array}{l}\text { The relative expression ratio } \\
\text { value }\end{array}$ & $\begin{array}{l}\text { The standard deviation of the } \\
\text { relative expression ratios }\end{array}$ \\
\hline O-EC1- & +1.79967448 & 0.31039898 \\
\hline O-EC1+ & +0.67108686 & 0.08788627 \\
\hline O-EC100- & +1.26826805 & 0.19793847 \\
\hline O-EC100+ & +2.81047034 & 0.35030524 \\
\hline O-AA1- & +2.51028463 & 0.34639867 \\
\hline O-AA1+ & +0.64786158 & 0.10575723 \\
\hline O-AA100- & +7.00519082 & 0.49586518 \\
\hline O-AA100+ & +9.56186163 & 1.3003321 \\
\hline O-control & +1.90774358 & 0.28106217 \\
\hline
\end{tabular}

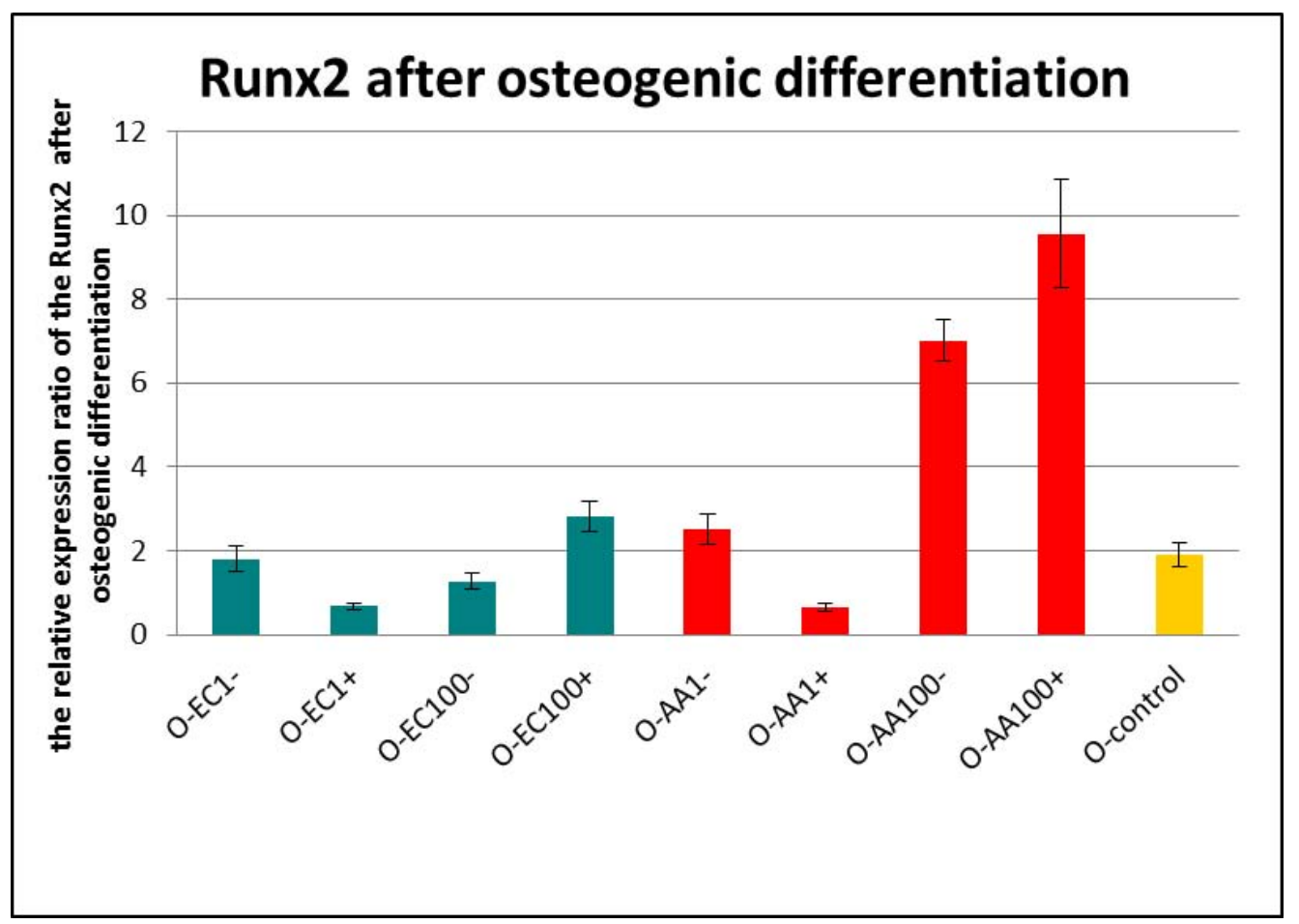

Figure 45

Table 6 and Figure 45: The relative expression ratios of the Runx2 gene in the 9 different cell experiments (O-AA1+, O-AA1-, O-AA100+, O-AA100-, OEC1+, O-EC1-, O-EC100+, O-EC100-, and O-control), after 2 weeks of 
incubation in the osteogenic differentiation medium. The Runx2 relative expression ratios were normalized to the expression levels of the $\beta 2 \mathrm{M}$.

Table 7:

\begin{tabular}{|l|l|l|}
\hline $\begin{array}{l}\text { Cell } \\
\text { experiment }\end{array}$ & $\begin{array}{l}\text { The relative expression } \\
\text { ratio value }\end{array}$ & $\begin{array}{l}\text { The standard deviation of the } \\
\text { relative expression ratios }\end{array}$ \\
\hline O-EC1- & 6.56452552 & 0.39405914 \\
\hline O-EC1+ & 0.57095362 & 0.05823776 \\
\hline O-EC100- & 0.63584312 & 0.10521236 \\
\hline O-EC100+ & 0.28422853 & 0.0374514 \\
\hline O-AA1- & 1.96580938 & 0.4641293 \\
\hline O-AA1+ & 0.22749373 & 0.03975667 \\
\hline O-AA100- & 1.53548708 & 0.2148489 \\
\hline O-AA100+ & 5.73755289 & 0.48272046 \\
\hline O-control & 1.32680252 & 0.28164993 \\
\hline
\end{tabular}

Table 7: The relative expression ratios of the Col1 gene in the 9 different cell experiments (O-AA1+, O-AA1-, O-AA100+, O-AA100-, O-EC1+, O-EC1-, OEC100+, O-EC100-, and O-control), after 2 weeks of incubation in the osteogenic differentiation medium. The Col1 relative expression ratios were normalized to the expression levels of the $\beta 2 \mathrm{M}$. 


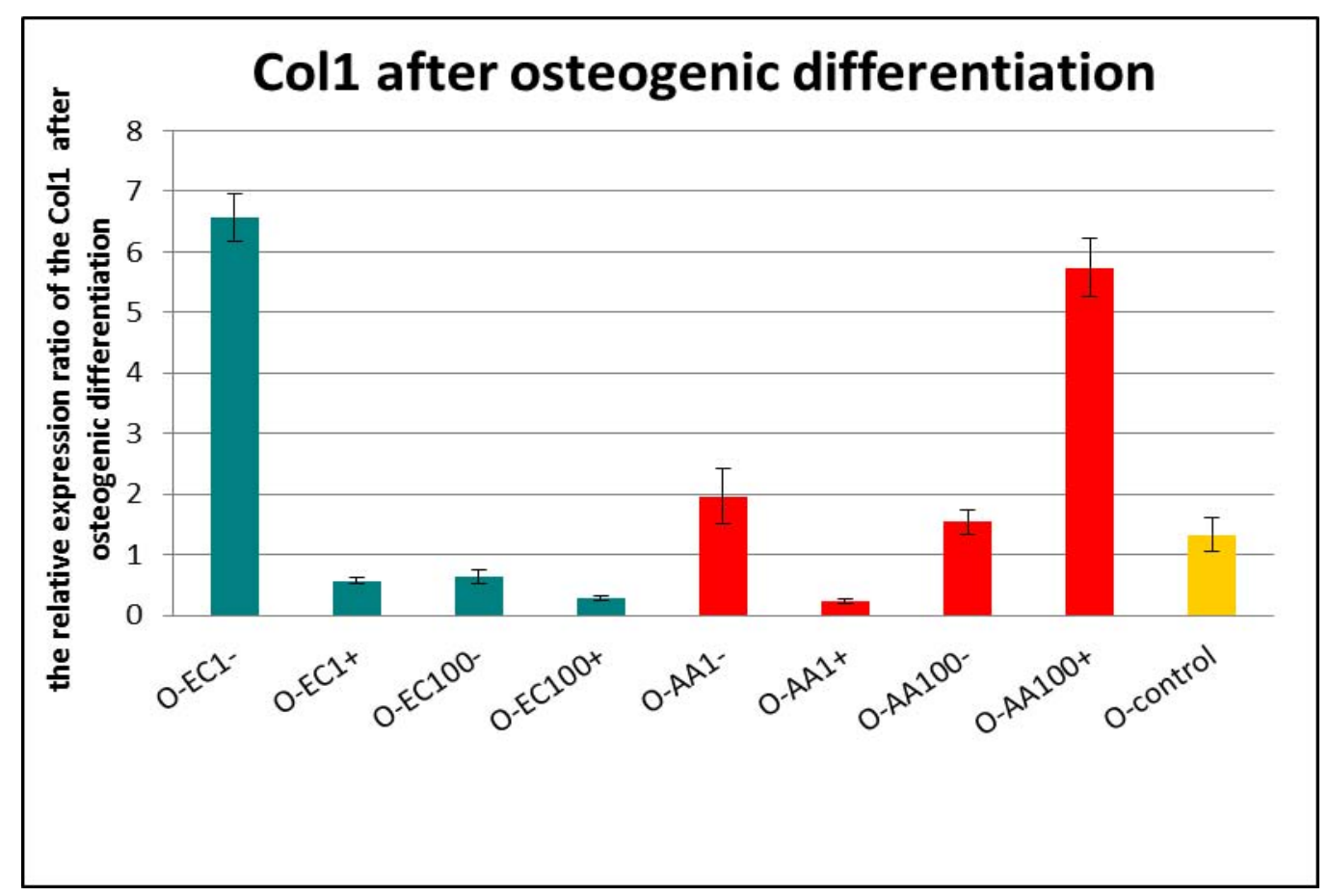

Figure 46

Figure 46: The relative expression ratios of the Col1 gene in the 9 different cell experiments (O-AA1+, O-AA1-, O-AA100+, O-AA100-, O-EC1+, O-EC1-, O-EC100+, O-EC100-, and O-control), after 2 weeks of incubation in the osteogenic differentiation medium. The Col1 relative expression ratios were normalized to the expression levels of the $\beta 2 \mathrm{M}$. 


\section{Discussion}

Periodontal diseases are the main cause of tooth loss. They constitute a substantial public health burden worldwide. Approximately, two thirds of German citizens suffer from periodontitis (Morsczeck et al. 2008). These periodontal diseases are characterized by the destruction of the periodontal supporting tissues including PDL, cementum, alveolar bone, and gingiva (Tan et al. 2009, Zhao et al. 2008). Periodontitis is initiated by bacterial colonization of the surfaces of the teeth in the region of the gingival sulcus and further extension of the bacterial plaque apically. Bacteria ingress themselves between the gingival tissues and the root surface to result in the extensive inflammation, pocket formation, and destruction of the soft tissue and the alveolar bone housing the root surfaces of the teeth (Srinivas et al. 2012). It is believed that most of the destruction of the soft and hard tissues of the periodontium is a result of the activation of the host-immune inflammatory response to the bacterial challenge (Offenbacher 1996). Offenbacher stated that, "the periodontopathic bacterial flora is necessary but not sufficient for disease" (Offenbacher 1996), stressing in his study, that was carried out in 1996, on the major role of the host-immune inflammatory response, rather than the bacterial role in the progressive and destructive nature of the disease.

More and more studies began to consider BMSCs as a preferable cell source for periodontal regeneration (Mizuno et al. 2008, Donzelli et al. 2007, George et al. 2006). Kawaguchi et al. autotransplanted BMSCs into experimental periodontal class III defects in beagle dogs, and found that the defects in the test group were regenerated with cementum, PDL, and alveolar bone. The transplanted BMSCs were found to be differentiated into various connective tissue cells in vivo under the influence of certain host factors. This influence of the local microenvironment on the BMSCs to differentiate into various 
specialized functional cells is a process known as site-specific differentiation of BMSCs (Krause et al. 2001, Quintavalla et al. 2002, Kawaguchi et al. 2004). A similar study was carried out by Hasegawa et al. in which the MSCs were labeled with green fluorescence protein (GFP), expanded in vitro, and then transplanted into experimental class III defects. After four weeks of transplantation, the periodontal defects were found to be almost completely regenerated with osteoblasts, osteocytes, and cementoblasts that were positive with the GFP when evaluated by immunohistochemical analysis (Hasegawa et al. 2006). Another study that was performed by Yang et al. on Sprague Dawley (SD) rats showed that; the experimental periodontal surgical defects that were regenerated with the BMSCs showed more appropriately oriented PDL fibers when compared to the control groups. Yang et al. transplanted rat BMSCs that were expanded in vitro on microcarrier gelatin beads, into surgically created periodontal defects. After three weeks of transplantation, histological evidences showed that the area of regenerated alveolar bone in the animals that received the cells and the bead-transplants were significantly larger than the area of regenerated alveolar bone in the control animals. Moreover, the PDL fibers that were regenerated in the animals that received the BMSCs gelatin beads showed more preferable perpendicularly oriented Sharpey's fibers (the PDL fibers that are inserted into the cementum), than the control groups, that showed disorganized nonfunctional regenerated Sharpey's fibers (Yang et al. 2010, Shimono et al. 2003).

On these bases, and according to the hypothesis of Offenbacher; concern in this study was mainly directed to elucidate the effects of the periodontopathic bacteria on the behavior of the MSCs regarding their stemness, degree of osteogenic differentiation, and proliferation capacity.

The human ki-67 is a protein that is associated with cell proliferation. Gerdes et al. were the first to prove that the ki-67 antigen is present only in the proliferating cells and absent in the resting cells. Gerdes demonstrated that when the resting cells were transformed into proliferating cells, for example, 
stimulation of the lymphocytes with phytohemagglutinin A (PHA), the ki-67 antigen was found to be apparent only in the nuclei of the proliferating cells, and absent from the nuclei of the non-stimulated resting lymphocytes. On the other hand, the ki-67 antigen disappears when the proliferating cells are induced to differentiate into resting cells (Gerdes et al. 1983, 1984). During the interphase, the ki-67 is detected only in the nucleus, and the protein is found to be present during all active phases of the cell cycle, but is absent from the resting cells, making it an excellent marker for determining the growth fraction and the proliferation rate of a given cell population (Kannan et al. 1996, Sittel et al. 1999).

Regarding the MSCs proliferation, this present study has shown that the cell numbers in most of the cell counts (with the Cellometer), and the expression of the ki-67 protein within the cells were increased linearly with the increased numbers (ratios) of the periodontopathic bacteria that were incubated with the cells. These findings were found to be consistent with the findings that were presented by MacNamara et al. in 2011. MacNamara, who worked on hematopoietic stem cells, demonstrated that the progenitor cells undergo a transition from a dormant state to an active state, and exhibit increased proliferation during in vivo bacterial infection with Ehrlichia muris (MacNamara et al. 2011). Although the non-hematopoietic stem cells differ from the hematopoietic stem cells, many studies suggested that they both exhibit a very close similar reaction to infection and injury (Morsczeck et al. 2008, Jones and McGonagle 2008). The same findings were also presented by Scumpia et al. who also stated that bacterial infection is a potent activator of hematopoietic stem and progenitor cell (HSPC) proliferation and expansion. Scumpia injected (intraperitoneal or i.p. injection) mutant mice with the lipopolysaccharides of the Escherichia coli, and according to his findings he proposed that the bacterial lipopolysaccharides are not only potent activators of the HSPC proliferation in vitro, but can also induce the same potent activation of HSPC proliferation in vivo (Scumpia et al. 2010). Another study, that was performed by Buchon et al. in 2010 also revealed a massive increase in the intestinal stem cell proliferation in the adult midgut of 
Drosophila (which is fairly similar to the gut of mammals), following the ingestion of a non-lethal pathogenic bacterium (Erwinia carotovora carotovora 15). The mammalian intestinal stem cells proliferate continuously to achieve a complete turnover of the gut every 3 to 4 days (Potten et al. 1992). Similarly, the Drosophila adult midgut contains a group of intestinal stem cells that also maintain its turnover integrity by producing a population of undifferentiated daughter cells that are termed enteroblasts (Ohlstein and Spradling 2006). Buchon et al. demonstrated in their study that was carried out in 2010 that in response to the ingestion of a non-lethal pathogenic bacterium, Erwinia carotovora carotovora 15, a dramatic remodeling of the Drosophila midgut occurs in order to repair a great loss of nearly its half cells' population. This dramatic remodeling and repair occurs through the immediate differentiation of the daughter enteroblasts, and through a massive increase in the proliferation of the intestinal stem cells (Buchon et al. 2010). Takemura who worked on the human periodontal ligament fibroblasts (HPLF), showed that in vitro responsiveness of the HPLF to the platelet derived growth factor (PDGF)-BB, a growth factor for mesenchymal stem cells, was highly improved with the presence of the lipopolysaccharides of Porphyromonas gingivalis. Takemura stated that, the Porphyromonas gingivalis lipopolysaccharides stimulate the cellular proliferation, and enhance the responsiveness of the cultured HLPF to the PDGF-BB factor (Takemura et al. 1998).

Findings of all of these previous studies support the idea of the increase in the stem cell proliferation in response to bacterial insult, and thus enforcing the results that were obtained from this present study regarding the elevated MSCs' proliferation levels with the increase in the numbers of the periodontopathic bacteria that were incubated with them.

Regarding the MSCs' stemness, the main concern in this study was to confirm that the MSCs still preserved their stemness after the two months of incubation with the periodontopathic bacteria. Böcker et al. who first introduced this immortalized hTERT hMSCs (SCP-1) cell line, showed positive reactions of these MSCs for the CD166, CD105, CD44, and CD29 
stem cell markers. Findings in this study showed that the MSCs were still able to demonstrate positive reactions with the same stem cell markers indicating that they still preserved their stemness after the incubation with the periodontopathic bacteria. To confirm these results, and to elucidate the exact effect of the bacterial incubation on the stemness of the cells, the MSCs were tested for relative expressions of the Klf4 and C-myc genes.

Many studies sought to reprogram somatic cells towards pluripotency (Takahashi and Yamanaka 2006, Cowan et al. 2005, Hansis et al. 2004, Alberio et al. 2006, Rodolfa and Eggan 2006). Lewitzky and Yamanaka reported that exogenous expression of sox2, oct4, klf4, and c-myc genes into somatic cells can reprogram them to give rise to cells with similarity to pluripotent cells, and thus they hypothesized that these genes are involved in the maintenance of the pluripotency of the stem cells. Another study perfomed by Sommer et al. reported the use of a single lentiviral vector expressing the four transcription factors c-myc, klf4, oct4, and sox2 in a single lentiviral stem cell cassette. All of the reprogrammed cells would receive the four factors accomplishing highly efficient induced pluripotent stem cells. This overcomes the problem that may occur during multiple viral integrations, as many of the reprogrammed cells may receive only one, two, or three factors, making it difficult to produce a homogenous population of induced pluripotent stem cells (Sommer et al. 2009).

The c-myc gene belongs to a family of helix-loop-helix/leucine zipper transcription factors. C-myc is associated with a number of cellular functions including cell growth, differentiation, proliferation, and transformation. The cmyc has been proposed as a major factor that supports the maintenance of pluripotency (Lewitzy and Yamanaka 2007, Cartwright et al. 2005). The potential role of $\mathrm{c}$-myc in the maintenance of the pluripotency in the stem cells is suggested by two reports. First, expression of an RLF/L-myc minigene, that delays the stem cells' differentiation and interferes with early embryonic development (MacLean-Hunter et al. 1994). Second, elevated c-myc activity is able to block the differentiation of multiple cell lineages (Selvakumaran et 
al. 1996, Canelles et al. 1997, Pelengaris et al. 1999, Schreiner et al. 2001, Knoepfler et al. 2002).

Smith et al. who worked on induced pluripotent stem cells, through the exogenous expression of sox2, oct4, and klf4 genes into mouse embryionic fibroblasts, according to the Takahashi and Yamanaka model in 2006, proposed that the c-myc has an important direct effect on repressing the expression of GATA6, which is a master regulator of primitive endoderm formation (Morrisey et al. 1998, Koutsourakis et al. 1999), and, therefore, they suggested that the c-myc plays an important role in the maintenance of pluripotency. Smith et al. hypothesized that the repressing effect applied by the c-myc on the GATA6 may have a transcriptional control basis, as the mycfamily-regulated miRNAs could potentially impact on the GATA6 translation. Smith also demonstrated that the loss of the c-myc and n-myc results in preferential differentiation of the induced pluripotent stem cells towards primitive endoderm (Smith et al. 2010).

Li et al. suggested that the klf4 acts as an inhibitor for the embryonic stem cell differentiation. The same suggestion was demonstrated by Lewitzky and Yamanaka who hypothesized that the overexpression of the klf4 leads to sustained expression of oct4 and inhibition of the differentiation in the embryonic stem cells. KIf4 also acts as a major downstream target for the LIF/STAT3 pathway, helping in maintaining the pluripotency of the embryonic stem cells (Li et al. 2005, Lewitzky and Yamanaka 2007).

This study showed that the relative expression ratios of the Klf4, and the Cmyc genes were increased in response to bacterial induction indicating that the MSCs not only preserved their stemness after incubation with bacteria, but also improved their stemness potential as well. Although this may contradict common sense at first glance, the consistency and the persistence of the relations between the relative expression ratios for both of the stemness genes (Klf4 and C-myc) within the four cell experiments (AA1, AA100, EC1, and EC100) enforces the previously obtained results. 
Regarding the capability of the MSCs to show osteogenic differentiation after the two months of incubation with the periodontopathic bacteria, findings of this study revealed that the MSCs were still able to produce positive reactions with the alkaline phosphatase staining after eight days of incubation in the osteogenic differentiation medium indicating that the MSCs still preserved their osteogenic character after the bacterial incubation.

Alkaline phosphatase is a glycoprotein that belongs to a family of proteins anchored to the plasma membrane via glycosylphosphatidylinositol linkages. It was found to act as a catalyst for the hydrolysis of phosphate esters in alkaline pH (Leung et al. 1993). Dziak, in 1992, stated that the alkaline phosphatase must be membrane-bound to start the mineralization process from solutions containing physiological concentrations of calcium and phosphate (Piattelli et al. 1996). Alkaline phosphatase is a common biochemical marker that is used to assess osteoblast differentiation and is considered to be involved in skeletal mineralization (Leung et al. 1993, Piattelli et al. 1996). Alkaline phosphatase was also found to be abundant in matrix vesicles which play an important role in extracellular matrix processing and calcification of bone (Harris 1990). Bellows et al. have shown that the levels of the alkaline phosphatase are increased just before mineralization is initiated. Despite the fact that the exact role of alkaline phosphatase in mineralization remains unclear, as it is widely distributed in all mammalian tissues, it still has important functions that are highly helpful to the mineralization process, as it is involved in the calcium-binding action, the generation of free phosphate, and the degradation of mineralization inhibitors (Bellows et al. 1991, Piattelli et al. 1995, 1996).

In order to confirm the results that were obtained with the alkaline phosphatase staining, the MSCs were checked for osteopontin occurrence with the help of immunohistochemistry. Osteopontin is an adhesive glycoprotein specifically localized in the mineralized extracellular matrix of bone and synthesized primarily by osteoblasts, endothelial cells and megakaryocytes (Wendel et al. 1998). Hultenby et al. stated that the 
osteopontin was found to be enriched at the mineralization front, and therefore they hypothesized its involvement in mineral deposition and growth. Osteopontin is one of the major non-collagenous proteins of bone which plays an important role in the regulation of bone mineralization; since it promotes the deposition of calcium phosphate (Martinez and Araujo 2004, Hultenby et al 1991), and regulates the growth of the hydroxyapatite crystals (Steitz et al. 2002). Reinholt et al. stated that osteopontin is crucially involved in anchoring osteoclasts to the mineral matrix of bone surfaces indicating that it is not only involved in mineral deposition, but generally implicated in the bone remodeling process (Reinholt et al. 1990). Another more recent study that was performed by Thurner et al. showed that the bone quality in osteopontin deficient mice was highly affected when compared to the wild types. Thurner revealed that osteopontin deficiency causes a 30\% decrease in the fracture resistance of the bone (Thurner et al. 2010).

This study demonstrated that all the different cell experiments $(\mathrm{O}-\mathrm{AA} 1+, \mathrm{O}-$ AA1-, O-EC1+, O-EC1-, O-AA100+, O-AA100-, O-EC1+, O-EC1-, O-control) showed positive immunohistochemical reactions for the osteopontin indicating and enforcing the osteogenic differentiation potential of the cells.

To elucidate the exact effects of the bacterial incubation on the osteogenic character of the MSCs, and to confirm the previous findings obtained from the alkaline phosphatase staining, and the immunohistochemical staining for osteopontin; cells in the different experiments were tested for the relative expression ratios of the osteogenic Runx2, and Col1 genes.

In vitro, the MSCs can be directed to the osteogenic differentiation lineage in the presence of $\beta$-glycerophosphate, ascorbic acid, and dexamethasone (Pittenger et al. 1999, Beresford et al. 1994). This process is regulated through the parallel and sequential expression of lineage specific genes. One of the most important transcription factors controlling this process is the Runx2 (Shui et al. 2003). Runx2 was found to be sufficient and necessary to direct the MSCs towards the osteoblastic lineage (Ziros et al. 2008). During the osteoblast differentiation Runx2 up-regulates the expression of bone 
matrix protein genes including Col1, Spp1, Ibsp, Bglap, and Fn1 and activates many promotors including those of Col1, Spp1, Bglap, and MMP-13 (Komori 2010). As the Runx2 induces the expression of major bone matrix genes in osteoblast progenitors, this allows the cells to acquire the osteoblastic phenotype while keeping the osteoblastic cells in an immature stage (Komori et al. 1997, Komori 2006). According to these concepts, the expressions of the Col1, and the Runx2 genes were evaluated with the help of the real time PCR in the MSCs of the different cell experiments, and the expression ratios were normalized to the expression levels of $\beta 2 \mathrm{M}$.

This study demonstrated that the MSCs in all the different cell experiments showed up-regulation for the Runx2 and Col1 genes after being directed to the osteogenic lineage enforcing the findings that were obtained with the alkaline phosphatase staining and the immunohistochemistry for the osteopontin. Regarding the findings that were obtained with the $(\mathrm{O}-\mathrm{EC} 1+)$, and the $(\mathrm{O}-\mathrm{AA} 1+)$ cells, as they always showed the lowest relative expression ratios with both of the Col1 and Runx2 genes, it may be possible that the addition of high numbers of bacteria (1:1 ratio) with the osteogenic differentiation medium may have affected the chemical composition of the differentiation medium resulting in the decrease of the osteogenic relative expression ratios demonstrated by the $(\mathrm{O}-\mathrm{A} A 1+)$ and $(\mathrm{O}-\mathrm{EC} 1+)$ cells. In general, and regarding the rest of the results obtained from the real time PCR, it can be stated that, with periodontopathogenic bacterial induction a highly positive effect of increasing and amplifying the osteogenic character of the MSCs can be accomplished.

Summarizing the findings that were obtained from this study, regarding the effects of the periodontopathic bacterial incubation on the proliferation, degree of stemness, and osteogenic differentiation of the hMSCs, it can be stated that the periodontal pathogenic induction can be used as an enhancing factor that can increase the hMSCs proliferation, and can improve and enhance their osteogenic differentiation potential at least in vitro. 
These findings may have a great impact on the stem cell field. Watt and Hogen, stated in their review that was published in the Science in 2000 that, "Usually between the stem cell and its terminally differentiated progeny there is an intermediate population of committed progenitors with limited proliferative capacity and restricted differentiation potential, known as transient amplifying cells, the primary function of this transient population is to increase the number of differentiated cells produced by each cell division. This means that, although a stem cell has high self-renewal capacity, it may actually divide relatively infrequently" (Watt and Hogen 2000). In this study the results suggest that with bacterial induction, increased stem cell proliferation can be obtained with preservation of the stemness potential of the cells and without the need of differentiation as a mandatory mean to increase the numbers of the cells. This means that increasing the frequency of the division of the stem cells can be obtained without the need of the stem cell differentiation.

A lot of further research has to be done in order to understand the specific mechanism through which the periodontopathic bacteria may contribute to the enhancement of the MSCs potential in the regeneration of periodontal defects. This will also help in the validation, correlation, and application of MSCs in the field of therapeutic stem cell research. 


\section{Summary}

For the first time the periodontal pathogens, namely the Actinobacillus actinomycetemcomitans, and the Eikenella corrodens were managed to be grown in the normal cell culture medium (DMEM). After stopping the growth of the bacteria with gentamycin, bacteria were incubated for two months with the immortalized hTERT hMSCs with the ratios of $1: 1$ and 1:100 resulting in five different cell-bacteria experiments (AA1, AA100, EC1, EC100, and control). Bacterial induction on the MSCs' proliferation was determined by cell counting applying the Cellometer and ki-67 via FACS analysis. The results suggested that the higher bacterial numbers (ratios), the higher the proliferation rate of the MSCs. During and after the two months of bacterial incubation, the MSCs were checked for the effect of bacterial induction in terms of stemness by applying immunohistochemistry for the stem cell markers (CD44, CD29, CD166, and CD105). Furthermore, real time PCR determined the relative expression ratios of the stemness markers C-myc, and Klf4 genes, and their effect on the relative expression of the osteogenic Col1, and Runx2 genes. Results that were obtained from the immunohistochemistry and the real time PCR showed that the MSCs in all of the different cell experiments still preserved their stemness after bacterial incubation. To confirm these previous results, MSCs in the different cell experiments were directed to the osteogenic differentiation lineage. The cells were divided into two major groups. One group was osteodifferentiated with the presence of bacteria $(\mathrm{O}-\mathrm{AA} 1+, \mathrm{O}-$ $\mathrm{AA100+}$, O-EC1+, and O-EC100+), while the other was osteodifferentiated without the presence of bacteria (O-AA1-, O-AA100-, O-EC1-, O-EC100-, and O-control). The osteodifferentiation was confirmed by alkaline phosphatase staining, and immunohistochemistry using antibodies against osteopontin. Cells in all of the nine different experiments demonstrated positive reactions with both of the alkaline phosphatase staining and the immunohistochemistry. Further, the degree of osteogenic induction was determined using the real 
time PCR for the Runx2 and Col1. MSCs in all of the nine different experiments showed up-regulation of both the Runx2 and Col1 genes confirming the osteodifferentiation.

Regarding the overall results obtained from this study, it can be stated that periodontal pathogenic induction with certain optimum concentrations can be used as an enhancing factor that can increase the proliferation and growth rates of the MSCs, and can improve and enhance their osteogenic differentiation potential at least in vitro. 


\section{References}

Alberio R, Campbell KH, Johnson AD (2006): Reprogramming somatic cells into stem cells. Reproduction 132, 709-720

Almasri A, Wisithphrom K, Windsor LJ, Olson B (2007): Nicotine and lipopolysaccharide affect cytokine expression from gingival fibroblasts. J Periodontol $\underline{78}, 533-541$

Avilion AA, Piatyszek MA, Gupta J, Shay JW, Bacchetti S, Greider CW (1996): Human telomerase RNA and telomerase activity in immortal cell lines and tumor tissues. Cancer Res $\underline{56}, 645-650$

Baxter MA, Wynn RF, Jowitt SN, Wraith JE, Fairbairn LJ, Bellantuono I (2004): Study of telomere length reveals rapid aging of human marrow stromal cells following in vitro expansion. Stem Cells $\underline{22}$, 675-682

Bellows CG, Aubin JE, Heersche JN (1991): Initiation and progression of mineralization of bone nodules formed in vitro: the role of alkaline phosphatase and organic phosphate. Bone Miner 14, 27-40

Beresford JN, Joyner CJ, Devlin C, Triffitt JT (1994): The effects of dexamethasone and 1,25-dihydroxyvitamin D3 on osteogenic differentiation of human marrow stromal cells in vitro. Arch Oral Biol 39, 941-947

Bianco P, Riminucci M, Gronthos S, Robey PG (2001): Bone marrow stromal stem cells: nature, biology, and potential applications. Stem Cells $\underline{19}$, 180-192 
Böcker W, Yin Z, Drosse I, Haasters F, Rossmann O, Wierer M, Popov C, Locher M, Mutschler W, Docheva D, Schieker M (2008): Introducing a singlecell-derived human mesenchymal stem cell line expressing hTERT after lentiviral gene transfer. J Cell Mol Med 12, 1347-1359

Buchon N, Broderick NA, Kuraishi T, Lemaitre B (2010): Drosophila EGFR pathway coordinates stem cell proliferation and gut remodeling following infection. BMC Biol $\underline{8}, 152$

Burns JS, Abdallah BM, Guldberg P, Rygaard J, Schroder HD, Kassem M (2005): Tumorigenic heterogeneity in cancer stem cells evolved from longterm cultures of telomerase-immortalized human mesenchymal stem cells. Cancer Res $\underline{65}$, 3126-3135

Canelles M, Delgado MD, Hyland KM, Lerga A, Richard C, Dang CV, Leon J (1997): Max and inhibitory c-Myc mutants induce erythroid differentiation and resistance to apoptosis in human myeloid leukemia cells. Oncogene $\underline{14}, 1315-$ 1327

Cartwright P, McLean C, Sheppard A, Rivett D, Jones K, Dalton S (2005): LIF/STAT3 controls ES cell self-renewal and pluripotency by a Mycdependent mechanism. Development $\underline{132}, 885-896$

Chen CK, Wilson ME (1992): Eikenella corrodens in human oral and non-oral infections: a review. J Periodontol $\underline{63}, 941-953$

Chen CK, Dunford RG, Reynolds HS, Zambon JJ (1989): Eikenella corrodens in the human oral cavity. J Periodontol $\underline{60}, 611-616$ 
Chen CK, Sunday GJ, Zambon JJ, Wilson ME (1990): Restriction endonuclease analysis of Eikenella corrodens. J Clin Microbiol 28, 1265-1270

Chen YL, Chen PK, Jeng LB, Huang CS, Yang LC, Chung HY, Chang SC (2008): Periodontal regeneration using ex vivo autologous stem cells engineered to express the BMP-2 gene: an alternative to alveolaplasty. Gene Ther $\underline{15}, 1469-1477$

Colombo AP, Boches SK, Cotton SL, Goodson JM, Kent R, Haffajee AD, Socransky SS, Hasturk H, Van Dyke TE, Dewhirst F, Paster BJ (2009): Comparisons of subgingival microbial profiles of refractory periodontitis, severe periodontitis, and periodontal health using the human oral microbe identification microarray. J Periodontol $\underline{80}, 1421-1432$

Counter CM, Meyerson M, Eaton EN, Weinberg RA (1997): The catalytic subunit of yeast telomerase. Proc Natl Acad Sci U S A $\underline{94}$, 9202-9207

Cowan CA, Atienza J, Melton DA, Eggan K (2005): Nuclear reprogramming of somatic cells after fusion with human embryonic stem cells. Science $\underline{309}$, 1369-1373

de Graaff J, van Winkelhoff AJ, Goene RJ (1989): The role of Actinobacillus actinomycetemcomitans in periodontal disease. Infection 17, 269-271

DiGirolamo CM, Stokes D, Colter D, Phinney DG, Class R, Prockop DJ (1999): Propagation and senescence of human marrow stromal cells in culture: a simple colony-forming assay identifies samples with the greatest potential to propagate and differentiate. $\mathrm{Br} \mathrm{J}$ Haematol 107, 275-281 
Docheva D, Padula D, Popov C, Weishaupt P, Pragert M, Miosge N, Hickel R, Böcker W, Clausen-Schaumann H, Schieker M (2010): Establishment of immortalized periodontal ligament progenitor cell line and its behavioural analysis on smooth and rough titanium surface. Eur Cell Mater $\underline{19}$, 228-241

Donzelli E, Salvade A, Mimo P, Vigano M, Morrone M, Papagna R, Carini F, Zaopo A, Miloso M, Baldoni M, Tredici G (2007): Mesenchymal stem cells cultured on a collagen scaffold: In vitro osteogenic differentiation. Arch Oral Biol $\underline{52}, 64-73$

Dutzan N, Gamonal J, Silva A, Sanz M, Vernal R (2009): Over-expression of forkhead box P3 and its association with receptor activator of nuclear factorkappa B ligand, interleukin (IL) -17, IL-10 and transforming growth factor-beta during the progression of chronic periodontitis. J Clin Periodontol $\underline{36}$, 396-403

Ebersole JL, Cappelli D (1994): Gingival crevicular fluid antibody to Actinobacillus actinomycetemcomitans in periodontal disease. Oral Microbiol Immunol $\underline{9}, 335-344$

Evans MJ, Kaufman MH (1981): Establishment in culture of pluripotential cells from mouse embryos. Nature 292, 154-156

Feng F, Liu CM, Hsu WC, Hou LT (1995): Long-term effects of gingival fibroblast-coated hydroxylapatite graft on periodontal osseous defects. J Formos Med Assoc 94, 494-498

Folgueras AR, Pendas AM, Sanchez LM, Lopez-Otin C (2004): Matrix metalloproteinases in cancer: from new functions to improved inhibition strategies. Int J Dev Biol $\underline{48}, 411-424$ 
Fortier LA (2005): Stem cells: classifications, controversies, and clinical applications. Vet Surg $\underline{34}, 415-423$

Friedenstein AJ, Piatetzky S, II, Petrakova KV (1966): Osteo-genesis in transplants of bone marrow cells. J Embryol Exp Morphol 16, 381-390

Friedenstein AJ, Chailakhjan RK, Lalykina KS (1970): The development of fibroblast colonies in monolayer cultures of guinea-pig bone marrow and spleen cells. Cell Tissue Kinet $\underline{3}, 393-403$

Friedenstein AJ, Latzinik NV, Gorskaya Yu F, Luria EA, Moskvina IL (1992): Bone marrow stromal colony formation requires stimulation by haemopoietic cells. Bone Miner $\underline{18}, 199-213$

Fuchs E (2012): The impact of cell culture on stem cell research. Cell Stem Cell $\underline{10}, 640-641$

Fujise O, Chen W, Rich S, Chen C (2004): Clonal diversity and stability of subgingival Eikenella corrodens. J Clin Microbiol 42, 2036-2042

Gajardo M, Silva N, Gomez L, Leon R, Parra B, Contreras A, Gamonal J (2005): Prevalence of periodontopathic bacteria in aggressive periodontitis patients in a Chilean population. J Periodontol $\underline{76}$, 289-294

George J, Kuboki Y, Miyata T (2006): Differentiation of mesenchymal stem cells into osteoblasts on honeycomb collagen scaffolds. Biotechnol Bioeng $\underline{95}$, 404-411 
Gerdes J, Schwab U, Lemke H, Stein H (1983): Production of a mouse monoclonal antibody reactive with a human nuclear antigen associated with cell proliferation. Int J Cancer $\underline{31}, 13-20$

Gerdes J, Lemke H, Baisch H, Wacker HH, Schwab U, Stein H (1984): Cell cycle analysis of a cell proliferation-associated human nuclear antigen defined by the monoclonal antibody Ki-67. J Immunol $\underline{133}, 1710-1715$

Golub LM, Lee HM, Greenwald RA, Ryan ME, Sorsa T, Salo T, Giannobile WV (1997): A matrix metalloproteinase inhibitor reduces bone-type collagen degradation fragments and specific collagenases in gingival crevicular fluid during adult periodontitis. Inflamm Res $\underline{46}$, 310-319

Goodson JM, Haffajee AD, Socransky SS (1984): The relationship between attachment level loss and alveolar bone loss. J Clin Periodontol 11, 348-359

Haffajee AD, Socransky SS (1994): Microbial etiological agents of destructive periodontal diseases. Periodontol $2000 \underline{5}, 78-111$

Haffajee AD, Socransky SS, Goodson JM (1983): Comparison of different data analyses for detecting changes in attachment level. J Clin Periodontol $\underline{10}, 298-310$

Hansis C, Barreto G, Maltry N, Niehrs C (2004): Nuclear reprogramming of human somatic cells by xenopus egg extract requires BRG1. Curr Biol $\underline{14}$, $1475-1480$

Harley CB (2002): Telomerase is not an oncogene. Oncogene 21, 494-502 
Harrington L, Zhou W, McPhail T, Oulton R, Yeung DS, Mar V, Bass MB, Robinson MO (1997): Human telomerase contains evolutionarily conserved catalytic and structural subunits. Genes Dev $\underline{11}, 3109-3115$

Harris H (1990): The human alkaline phosphatases: what we know and what we don't know. Clin Chim Acta 186, 133-150

Hasegawa N, Kawaguchi H, Hirachi A, Takeda K, Mizuno N, Nishimura M, Koike C, Tsuji K, Iba H, Kato Y, Kurihara H (2006): Behavior of transplanted bone marrow-derived mesenchymal stem cells in periodontal defects. J Periodontol $\underline{77}, 1003-1007$

Hernandez M, Dutzan N, Garcia-Sesnich J, Abusleme L, Dezerega A, Silva N, Gonzalez FE, Vernal R, Sorsa T, Gamonal J (2011): Host-pathogen interactions in progressive chronic periodontitis. J Dent Res $\underline{90}, 1164-1170$

Hernandez Rios M, Sorsa T, Obregon F, Tervahartiala T, Valenzuela MA, Pozo P, Dutzan N, Lesaffre E, Molas M, Gamonal J (2009): Proteolytic roles of matrix metalloproteinase (MMP)-13 during progression of chronic periodontitis: initial evidence for MMP-13/MMP-9 activation cascade. J Clin Periodontol $\underline{36}, 1011-1017$

http://microbewiki.kenyon.edu (2007)

http://www.erdent.com (2012)

http://www.perio.org (2012) 
Hultenby K, Reinholt FP, Oldberg A, Heinegard D (1991): Ultrastructural immunolocalization of osteopontin in metaphyseal and cortical bone. Matrix $\underline{11}, 206-213$

Ivanovski S, Gronthos S, Shi S, Bartold PM (2006): Stem cells in the periodontal ligament. Oral Dis $\underline{12}$, 358-363

Jiang $Y$, Jahagirdar BN, Reinhardt RL, Schwartz RE, Keene CD, OrtizGonzalez XR, Reyes M, Lenvik T, Lund T, Blackstad M, Du J, Aldrich S, Lisberg A, Low WC, Largaespada DA, Verfaillie CM (2002): Pluripotency of mesenchymal stem cells derived from adult marrow. Nature $\underline{418}, 41-49$

Jones E, McGonagle D (2008): Human bone marrow mesenchymal stem cells in vivo. Rheumatology (Oxford) $\underline{47}, 126-131$

Jönsson D, Nebel D, Bratthall G, Nilsson BO (2008): LPS-induced MCP-1 and IL-6 production is not reversed by oestrogen in human periodontal ligament cells. Arch Oral Biol $\underline{53}, 896-902$

Jönsson D, Amisten S, Bratthall G, Holm A, Nilsson BO (2009): LPS induces GROalpha chemokine production via NF-kappaB in oral fibroblasts. Inflamm Res $\underline{58}, 791-796$

Jönsson D, Nebel D, Bratthall G, Nilsson BO (2011): The human periodontal ligament cell: a fibroblast-like cell acting as an immune cell. J Periodontal Res $\underline{46}, 153-157$ 
Kannan R, Bijur GN, Mallery SR, Beck FM, Sabourin CL, Jewell SD, Schuller DE, Stoner GD (1996): Transforming growth factor-alpha overexpression in proliferative verrucous leukoplakia and oral squamous cell carcinoma: an immunohistochemical study. Oral Surg Oral Med Oral Pathol Oral Radiol Endod $\underline{82}, 69-74$

Kaplan JB, Perry MB, MacLean LL, Furgang D, Wilson ME, Fine DH (2001): Structural and genetic analyses of $O$ polysaccharide from Actinobacillus actinomycetemcomitans serotype f. Infect Immun $\underline{69}$, 5375-5384

Kawaguchi $H$, Hirachi A, Hasegawa N, Iwata T, Hamaguchi $H$, Shiba $H$, Takata T, Kato Y, Kurihara H (2004): Enhancement of periodontal tissue regeneration by transplantation of bone marrow mesenchymal stem cells. $J$ Periodontol $\underline{75}, 1281-1287$

Kinane DF (2001): Causation and pathogenesis of periodontal disease. Periodontol $2000 \underline{25}$, 8-20

Kiuru M, Boyer JL, O'Connor TP, Crystal RG (2009): Genetic control of wayward pluripotent stem cells and their progeny after transplantation. Cell Stem Cell $\underline{4}, 289-300$

Knoepfler PS, Cheng PF, Eisenman RN (2002): N-myc is essential during neurogenesis for the rapid expansion of progenitor cell populations and the inhibition of neuronal differentiation. Genes Dev 16, $2699-2712$

Kohn DB (2007): Lentiviral vectors ready for prime-time. Nat Biotechnol $\underline{25}$, 65-66 
Komori T (2006): Regulation of osteoblast differentiation by transcription factors. J Cell Biochem 99, 1233-1239

Komori T (2010): Regulation of bone development and extracellular matrix protein genes by RUNX2. Cell Tissue Res $\underline{339}$, 189-195

Komori T, Yagi H, Nomura S, Yamaguchi A, Sasaki K, Deguchi K, Shimizu Y, Bronson RT, Gao YH, Inada M, Sato M, Okamoto R, Kitamura Y, Yoshiki S, Kishimoto T (1997): Targeted disruption of Cbfa1 results in a complete lack of bone formation owing to maturational arrest of osteoblasts. Cell $\underline{89}, 755-764$

Koutsourakis M, Langeveld A, Patient R, Beddington R, Grosveld F (1999): The transcription factor GATA6 is essential for early extraembryonic development. Development 126, 723-732

Krause DS, Theise ND, Collector MI, Henegariu O, Hwang S, Gardner R, Neutzel S, Sharkis SJ (2001): Multi-organ, multi-lineage engraftment by a single bone marrow-derived stem cell. Cell 105, 369-377

Lakio L, Paju S, Alfthan G, Tiirola T, Asikainen S, Pussinen PJ (2003): Actinobacillus actinomycetemcomitans serotype d-specific antigen contains the $O$ antigen of lipopolysaccharide. Infect Immun $\underline{71}, 5005-5011$

Lendvay TS, Morris DK, Sah J, Balasubramanian B, Lundblad V (1996): Senescence mutants of Saccharomyces cerevisiae with a defect in telomere replication identify three additional EST genes. Genetics $\underline{144}, 1399-1412$

Leo AJ, Grande DA (2006): Mesenchymal stem cells in tissue engineering. Cells Tissues Organs $\underline{183}, 112-122$ 
Leung KS, Fung KP, Sher AH, Li CK, Lee KM (1993): Plasma bone-specific alkaline phosphatase as an indicator of osteoblastic activity. J Bone Joint Surg $\mathrm{Br} \underline{75}, 288-292$

Lewitzky M, Yamanaka S (2007): Reprogramming somatic cells towards pluripotency by defined factors. Curr Opin Biotechnol 18, 467-473

Li Y, McClintick J, Zhong L, Edenberg HJ, Yoder MC, Chan RJ (2005): Murine embryonic stem cell differentiation is promoted by SOCS-3 and inhibited by the zinc finger transcription factor klf4. Blood 105, 635-637

MacLean-Hunter S, Makela TP, Grzeschiczek A, Alitalo K, Moroy T (1994): Expression of a rlf/L-myc minigene inhibits differentiation of embryonic stem cells and embroid body formation. Oncogene $\underline{9}$, 3509-3517

MacNamara KC, Jones M, Martin O, Winslow GM (2011): Transient activation of hematopoietic stem and progenitor cells by IFNgamma during acute bacterial infection. PLoS One $\underline{6}$, e28669

Mandell RL (1984): A longitudinal microbiological investigation of Actinobacillus actinomycetemcomitans and Eikenella corrodens in juvenile periodontitis. Infect Immun $\underline{45}, 778-780$

Mandell RL, Ebersole JL, Socransky SS (1987): Clinical immunologic and microbiologic features of active disease sites in juvenile periodontitis. J Clin Periodontol 14, 534-540 
Mantyla P, Stenman M, Kinane D, Salo T, Suomalainen K, Tikanoja S, Sorsa T (2006): Monitoring periodontal disease status in smokers and nonsmokers using a gingival crevicular fluid matrix metalloproteinase-8-specific chair-side test. J Periodontal Res $\underline{41}$, 503-512

Maria OM, Khosravi R, Mezey E, Tran SD (2007): Cells from bone marrow that evolve into oral tissues and their clinical applications. Oral Dis $\underline{13}, 11-16$

Martinez EF, Araujo VC (2004): In vitro immunoexpression of extracellular matrix proteins in dental pulpal and gingival human fibroblasts. Int Endod $\mathrm{J}$ $\underline{37}, 749-755$

Meyerson M, Counter CM, Eaton EN, Ellisen LW, Steiner P, Caddle SD, Ziaugra L, Beijersbergen RL, Davidoff MJ, Liu Q, Bacchetti S, Haber DA, Weinberg RA (1997): hEST2, the putative human telomerase catalytic subunit gene, is up-regulated in tumor cells and during immortalization. Cell $\underline{90}, 785-$ 795

Mizuno N, Ozeki Y, Shiba H, Kajiya M, Nagahara T, Takeda K, Kawaguchi H, Abiko $Y$, Kurihara $H$ (2008): Humoral factors released from human periodontal ligament cells influence calcification and proliferation in human bone marrow mesenchymal stem cells. J Periodontol $\underline{79}, 2361-2370$

Morrisey EE, Tang Z, Sigrist K, Lu MM, Jiang F, Ip HS, Parmacek MS (1998): GATA6 regulates HNF4 and is required for differentiation of visceral endoderm in the mouse embryo. Genes Dev $\underline{12}, 3579-3590$

Morsczeck C, Schmalz G, Reichert TE, Vollner F, Galler K, Driemel O (2008): Somatic stem cells for regenerative dentistry. Clin Oral Investig $\underline{12}, 113-118$ 
Mudda JA, Bajaj M (2011): Stem cell therapy: a challenge to periodontist. Indian J Dent Res 르, 132-139

Nakamura TM, Morin GB, Chapman KB, Weinrich SL, Andrews WH, Lingner J, Harley CB, Cech TR (1997): Telomerase catalytic subunit homologs from fission yeast and human. Science $\underline{277}, 955-959$

Nakayama J, Saito M, Nakamura H, Matsuura A, Ishikawa F (1997): TLP1: a gene encoding a protein component of mammalian telomerase is a novel member of WD repeats family. Cell $\underline{88}, 875-884$

Offenbacher S (1996): Periodontal diseases: pathogenesis. Ann Periodontol 1, 821-878

Ohlstein B, Spradling A (2006): The adult Drosophila posterior midgut is maintained by pluripotent stem cells. Nature $\underline{439}, 470-474$

Park JY, Jeon SH, Choung PH (2011): Efficacy of periodontal stem cell transplantation in the treatment of advanced periodontitis. Cell Transplant $\underline{20}$, 271-285

Pelengaris S, Littlewood T, Khan M, Elia G, Evan G (1999): Reversible activation of c-myc in skin: induction of a complex neoplastic phenotype by a single oncogenic lesion. Mol Cell $\underline{3}, 565-577$

Perry MB, MacLean LL, Gmur R, Wilson ME (1996): Characterization of the O-polysaccharide structure of lipopolysaccharide from Actinobacillus actinomycetemcomitans serotype b. Infect Immun $\underline{64}, 1215-1219$ 
Pfaffl MW (2001): A new mathematical model for relative quantification in realtime RT-PCR. Nucleic Acids Res $\underline{29}$, e45

Pfaffl MW, Horgan GW, Dempfle L (2002): Relative expression software tool (REST) for group-wise comparison and statistical analysis of relative expression results in real-time PCR. Nucleic Acids Res $\underline{30}$, e36

Pfeifer A, Ikawa M, Dayn Y, Verma IM (2002): Transgenesis by lentiviral vectors: lack of gene silencing in mammalian embryonic stem cells and preimplantation embryos. Proc Natl Acad Sci U S A 99, 2140-2145

Phinney DG, Prockop DJ (2007): Concise review: mesenchymal stem/multipotent stromal cells: the state of transdifferentiation and modes of tissue repair--current views. Stem Cells $\underline{25}$, 2896-2902

Piattelli A, Scarano A, Piattelli M (1995): Detection of alkaline and acid phosphatases around titanium implants: a light microscopical and histochemical study in rabbits. Biomaterials $\underline{16}, 1333-1338$

Piattelli A, Scarano A, Corigliano M, Piattelli M (1996): Effects of alkaline phosphatase on bone healing around plasma-sprayed titanium implants: a pilot study in rabbits. Biomaterials $\underline{17}, 1443-1449$

Pittenger MF, Mackay AM, Beck SC, Jaiswal RK, Douglas R, Mosca JD, Moorman MA, Simonetti DW, Craig S, Marshak DR (1999): Multilineage potential of adult human mesenchymal stem cells. Science $\underline{284}, 143-147$

Potten CS, Kellett M, Rew DA, Roberts SA (1992): Proliferation in human gastrointestinal epithelium using bromodeoxyuridine in vivo: data for different sites, proximity to a tumour, and polyposis coli. Gut $\underline{33}, 524-529$ 
Quintavalla J, Uziel-Fusi S, Yin J, Boehnlein E, Pastor G, Blancuzzi V, Singh HN, Kraus KH, O'Byrne E, Pellas TC (2002): Fluorescently labeled mesenchymal stem cells (MSCs) maintain multilineage potential and can be detected following implantation into articular cartilage defects. Biomaterials $\underline{23}, 109-119$

Reinholt FP, Hultenby K, Oldberg A, Heinegard D (1990): Osteopontin--a possible anchor of osteoclasts to bone. Proc Natl Acad Sci U S A $\underline{87}$, 44734475

Riggio MP, Macfarlane TW, Mackenzie D, Lennon A, Smith AJ, Kinane D (1996): Comparison of polymerase chain reaction and culture methods for detection of Actinobacillus actinomycetemcomitans and Porphyromonas gingivalis in subgingival plaque samples. J Periodontal Res $\underline{31}, 496-501$

Rodolfa KT, Eggan K (2006): A transcriptional logic for nuclear reprogramming. Cell 126, 652-655

Sakurai K, Wang D, Suzuki J, Umeda M, Nagasawa T, Izumi Y, Ishikawa I, Isobe M (2007): High incidence of actinobacillus actinomycetemcomitans infection in acute coronary syndrome. Int Heart J $\underline{48}, 663-675$

Salari MH, Kadkhoda Z (2004): Rate of cultivable subgingival periodontopathogenic bacteria in chronic periodontitis. J Oral Sci $\underline{46}, 157-161$

Schreiner S, Birke M, Garcia-Cuellar MP, Zilles O, Greil J, Slany RK (2001): MLL-ENL causes a reversible and myc-dependent block of myelomonocytic cell differentiation. Cancer Res $\underline{61}, 6480-6486$ 
Scumpia PO, Kelly-Scumpia KM, Delano MJ, Weinstein JS, Cuenca AG, AlQuran S, Bovio I, Akira S, Kumagai Y, Moldawer LL (2010): Cutting edge: bacterial infection induces hematopoietic stem and progenitor cell expansion in the absence of TLR signaling. J Immunol $\underline{184}, 2247-2251$

Selvakumaran M, Liebermann D, Hoffman B (1996): The proto-oncogene cmyc blocks myeloid differentiation independently of its target gene ornithine decarboxylase. Blood $\underline{88}, 1248-1255$

Shi S, Bartold PM, Miura M, Seo BM, Robey PG, Gronthos S (2005): The efficacy of mesenchymal stem cells to regenerate and repair dental structures. Orthod Craniofac Res $\underline{8}, 191-199$

Shimono M, Ishikawa $T$, Ishikawa $H$, Matsuzaki $H$, Hashimoto $S$, Muramatsu T, Shima K, Matsuzaka K, Inoue T (2003): Regulatory mechanisms of periodontal regeneration. Microsc Res Tech $\underline{60}, 491-502$

Shui C, Spelsberg TC, Riggs BL, Khosla S (2003): Changes in Runx2/Cbfa1 expression and activity during osteoblastic differentiation of human bone marrow stromal cells. J Bone Miner Res $\underline{18}$, 213-221

Simmons PJ, Torok-Storb B (1991): Identification of stromal cell precursors in human bone marrow by a novel monoclonal antibody, STRO-1. Blood $\underline{78}, 55-$ 62

Simonsen JL, Rosada C, Serakinci N, Justesen J, Stenderup K, Rattan SI, Jensen TG, Kassem M (2002): Telomerase expression extends the proliferative life-span and maintains the osteogenic potential of human bone marrow stromal cells. Nat Biotechnol 므, 592-596 
Singer NG, Caplan Al (2011): Mesenchymal stem cells: mechanisms of inflammation. Annu Rev Pathol $\underline{6}$, 457-478

Sittel C, Ruiz S, Volling P, Kvasnicka HM, Jungehulsing M, Eckel HE (1999): Prognostic significance of Ki-67 (MIB1), PCNA and p53 in cancer of the oropharynx and oral cavity. Oral Oncol $\underline{35}, 583-589$

Smith KN, Singh AM, Dalton S (2010): Myc represses primitive endoderm differentiation in pluripotent stem cells. Cell Stem Cell $\underline{7}$, 343-354

Socransky SS, Smith C, Haffajee AD (2002): Subgingival microbial profiles in refractory periodontal disease. J Clin Periodontol 29, 260-268

Sommer CA, Stadtfeld M, Murphy GJ, Hochedlinger K, Kotton DN, Mostoslavsky G (2009): Induced pluripotent stem cell generation using a single lentiviral stem cell cassette. Stem Cells $\underline{27}, 543-549$

Song L, Webb NE, Song Y, Tuan RS (2006): Identification and functional analysis of candidate genes regulating mesenchymal stem cell self-renewal and multipotency. Stem Cells $\underline{24}, 1707-1718$

Souza PP, Palmqvist P, Lundgren I, Lie A, Costa-Neto CM, Lundberg P, Lerner UH (2010): Stimulation of IL-6 cytokines in fibroblasts by toll-like receptors 2. J Dent Res $\underline{89}$, 802-807

Srinivas M, Chethana KC, Padma R, Suragimath G, Anil M, Pai BS, Walvekar A (2012): A study to assess and compare the peripheral blood neutrophil chemotaxis in smokers and non smokers with healthy periodontium, gingivitis, and chronic periodontitis. J Indian Soc Periodontol 16, 54-58 
Steitz SA, Speer MY, McKee MD, Liaw L, Almeida M, Yang H, Giachelli CM (2002): Osteopontin inhibits mineral deposition and promotes regression of ectopic calcification. Am J Pathol 161, 2035-2046

Stenderup K, Justesen J, Clausen C, Kassem M (2003): Aging is associated with decreased maximal life span and accelerated senescence of bone marrow stromal cells. Bone $\underline{33}, 919-926$

Suwanagool S, Rothkopf MM, Smith SM, LeBlanc D, Eng R (1983): Pathogenicity of Eikenella corrodens in humans. Arch Intern Med 143, 22652268

Takahashi K, Yamanaka S (2006): Induction of pluripotent stem cells from mouse embryonic and adult fibroblast cultures by defined factors. Cell $\underline{126}$, 663-676

Takemura A, Matsuda N, Kimura S, Fujiwara T, Nakagawa I, Hamada S (1998): Porphyromonas gingivalis lipopolysaccharide modulates the responsiveness of human periodontal ligament fibroblasts to platelet-derived growth factor. J Periodontal Res $\underline{33}, 400-407$

Takeuchi Y, Umeda M, Ishizuka M, Huang Y, Ishikawa I (2003): Prevalence of periodontopathic bacteria in aggressive periodontitis patients in a Japanese population. J Periodontol $\underline{74}, 1460-1469$

Tan Z, Zhao Q, Gong P, Wu Y, Wei N, Yuan Q, Wang C, Liao D, Tang H (2009): Research on promoting periodontal regeneration with human basic fibroblast growth factor-modified bone marrow mesenchymal stromal cell gene therapy. Cytotherapy $\underline{11}, 317-325$ 
Thurner PJ, Chen CG, Ionova-Martin S, Sun L, Harman A, Porter A, Ager JW, 3rd, Ritchie RO, Alliston T (2010): Osteopontin deficiency increases bone fragility but preserves bone mass. Bone $\underline{46}, 1564-1573$

Umehara H, Kimura T, Ohtsuka S, Nakamura T, Kitajima K, Ikawa M, Okabe M, Niwa H, Nakano T (2007): Efficient derivation of embryonic stem cells by inhibition of glycogen synthase kinase-3. Stem Cells 25, 2705-2711

Vernal R, Garcia-Sanz JA (2008): Th17 and Treg cells, two new lymphocyte subpopulations with a key role in the immune response against infection. Infect Disord Drug Targets $\underline{8}, 207-220$

Vernal R, Chaparro A, Graumann R, Puente J, Valenzuela MA, Gamonal J (2004): Levels of cytokine receptor activator of nuclear factor kappaB ligand in gingival crevicular fluid in untreated chronic periodontitis patients. J Periodontol $\underline{75}, 1586-1591$

Watt FM, Hogan BL (2000): Out of Eden: stem cells and their niches. Science $\underline{287}, 1427-1430$

Wendel M, Sommarin Y, Heinegard D (1998): Bone matrix proteins: isolation and characterization of a novel cell-binding keratan sulfate proteoglycan (osteoadherin) from bovine bone. J Cell Biol 141, 839-847

Yamaji Y, Kubota T, Sasaguri K, Sato S, Suzuki Y, Kumada H, Umemoto T (1995): Inflammatory cytokine gene expression in human periodontal ligament fibroblasts stimulated with bacterial lipopolysaccharides. Infect Immun $\underline{63}$, 3576-3581 
Yanagita M, Kojima Y, Mori K, Yamada S, Murakami S (2011): Osteoinductive and anti-inflammatory effect of royal jelly on periodontal ligament cells. Biomed Res $\underline{32}, 285-291$

Yang Y, Rossi FM, Putnins EE (2010): Periodontal regeneration using engineered bone marrow mesenchymal stromal cells. Biomaterials $\underline{31}$, 85748582

Ye L, Fan Z, Yu B, Chang J, Al Hezaimi K, Zhou X, Park NH, Wang CY (2012): Histone Demethylases KDM4B and KDM6B Promotes Osteogenic Differentiation of Human MSCs. Cell Stem Cell 11, 50-61

Zhao Q, Gong P, Tan Z, Yang X (2008): Differentiation control of transplanted mesenchymal stem cells (MSCs): a new possible strategy to promote periodontal regeneration. Med Hypotheses $\underline{70}$, 944-947

Zimmermann S, Voss M, Kaiser S, Kapp U, Waller CF, Martens UM (2003): Lack of telomerase activity in human mesenchymal stem cells. Leukemia $\underline{17}$, 1146-1149

Ziros PG, Basdra EK, Papavassiliou AG (2008): Runx2: of bone and stretch. Int J Biochem Cell Biol 무, 1659-1663 


\section{Acknowledgements}

This dissertation would not have been possible without the guidance and the help of several individuals who, in one way or another, contributed and extended their valuable assistance in the preparation and completion of this study.

First and foremost, my utmost gratitude to Prof. Dr. med. Nicolai Miosge, whose sincerity and encouragement I will never forget. Prof. Miosge has been my inspiration as I hurdle all the obstacles in the completion of this research work. I will always remain grateful to his support, guidance, and precise supervision that genuinely helped me.

I also would like to thank Prof. Dr. med. Matthias Schieker from the Faculty of Medicine, München University, who generously provided us with the SCP-1 stem cells.

My deep thanks to Prof. Dr. med. Dr. rer. nat. Helmut Eiffert, and Frau Silvia Kellner from the Microbiology Department, Faculty of Medicine, University of Göttingen, who kindly provided me with great help regarding the bacterial work.

My great thanks to Frau Boguslawa Sadowski for her great help with the FACS analysis.

And finally, my sincere thanks to all of my colleagues in the tissue regeneration work group for the good and motivating work atmosphere, especially Hayat Muhammed and Frau Christa Bode, who genuinely helped me a lot with acquiring the different laboratory skills. 


\section{Lebenslauf}

Am 21. Juni 1986 wurde ich als einziger Sohn von Frau Omayma Abu Zeid und Prof. Mohamed Baligh in Kairo geboren. Meine Mutter ist Hausfrau, und mein Vater ist Professor für Ophthalmologie. Von 1990 bis 2003 besuchte ich die multilinguale El Nozha Schule in Kairo, an welcher ich im Jahr 2003 mein Abitur ablegte. Im September 2003 begann ich das Studium der Zahnmedizin an der Zahnmedizinischen Fakultät der Universität Kairo. Nach fünf Jahren, im Juni 2008 bekam ich den „Bachelor der Zahnmedizin“. Von November 2008 bis Oktober 2009 machte ich mein Praktisches Jahr als Zahnarzt im AlQasr Al-Ainy Krankenhaus (der Universität Kairo). Im Juni 2009 begann ich meine Karriere als Zahnarzt in einer privaten Praxis in Kairo. Von Dezember 2009 bis Juni 2011 arbeitete ich als Zahnarzt im Nationalen Forschungszentrum in der Abteilung Orodentalgenetik.

Von Juni bis Dezember 2010 arbeitete ich als Zahn-Mund-Kiefer-Chirurg im Ahmad Maher Krankenhaus in Kairo.

Im November 2010 kam ich zum ersten Mal nach Deutschland als Teilnehmer von BIMUN/SINUB (Bonn International Model of United Nations) welches eine Simulation der UNO-Vollversammlung von Jugendlichen darstellt.

Am 25.Januar 2011 begann unsere wichtige Revolution in Ägypten. Und ich danke Gott dass ich ein Teil dieser heiligen Revolution war, den Tag erlebten durfte, an dem ich einen anderen Präsidenten als Hosny Mubarak bekam. Im Juli 2011 kam ich nach Deutschland und begann mit den experimentellen Arbeiten zu meiner Doktorarbeit unter der Leitung von Prof. Dr. Nicolai Miosge in der Abteilung Prothetik an der Universitätsmedizin Göttingen. 